The Structure of the

(O) molic Mountains, Washington-

Analysis of a Subduction \%one

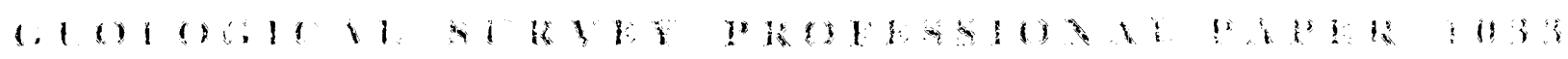




\title{
The Structure of the Olympic Mountains, Washington- Analysis of a Subduction Zone
}

\author{
By R. W. TABOR and W. M. CADY
}

GEOLOGICAL S URVEY PROFESSIONAL PAPER 1033

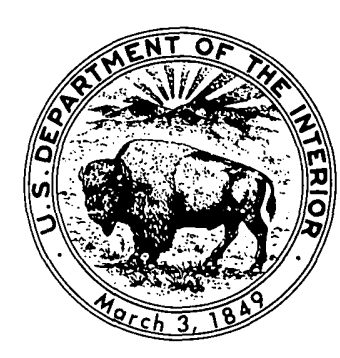

UNITED STATES GOVERNMENT PRINTING OFFICE, WASHINGTON : 1978 


\section{UNITED STATES DEPARTMENT OF THE INTERIOR}

CECIL D. ANDRUS, Secretary

\section{GEOLOGICAL SURVEY}

H. William Menard, Director

Library of Congress Cataloging in Publication Data

Tabor, Rowland W.

The structure of the Olympic Mountains, Washington.

Geological Survey Professional Paper 1033

Bibliography: p. 24-25.

1. Geology-Washington (State)-Olympic Mountains. 1. Cady, Wallace Martin, 1912- joint author

II. Title. III. Series: United States Geological Survey Professional Paper 1033

QE176.038T3 $\quad 557.97$ '94

76-606187

For sale by the Superintendent of Documents, U.S. Government Printing Office

Washington, D.C. 20402

Stock No. 024-001-03079-9 


\section{CONTENTS}

\begin{tabular}{|c|c|}
\hline Pag & Page \\
\hline - & Structural geology of the eastern core-Continued \\
\hline Introduction & Tectonic fabric-Continued \\
\hline Summary of regional geology & Pencil structures \\
\hline Procedure and acknowledgments & Stretched clast lineations \\
\hline Structural geology of the eastern core & Major structural terranes \\
\hline Overview of the structure & Multiple folding \\
\hline Major rock units & Early folding - formation of the core units \\
\hline Faults bounding the core & Late folding and doming_formation of the pencils _._. 19 \\
\hline Significance of top directions & Summary of the deformation \\
\hline Tectonic versus soft-sediment slump structure & Plate margin tectonics \\
\hline Tectonic fabric & References cited \\
\hline Cleavage & Supplemental information \\
\hline Folds - & $\begin{array}{l}\text { Frequency diagrams for subdomains } \\
\text { Computerized structural diagram program }\end{array}$ \\
\hline
\end{tabular}

\section{ILLUSTRATIONS}

Figure

1. Sketch map showing major geologic terranes of the Olympic Peninsula

2. Geologic map of the eastern core

. Sketch map showing major folds and faults on the Olympic Peninsula

4-8. Photographs showing:

4. Beds sheared off by cleavage in zone of disruption, Hurricane Ridge fault zone south of Mount Angeles $\quad \ldots . .-7$

5. Block of undisrupted thin-bedded sandstone and slate in broken formation, western Olympic lithic assemblage 8

6. Shear fold in thin-bedded sandstone with slate core, southwest of Mount Olympus

7. Sheared-off sandstone bed in weakly developed slate, south side Mount Appleton _..... 8

8. Sketches showing beds in sandstone and slate disrupted by cleavage

9-15. Photographs showing:

9. Blocks and lenses of sandstone in contorted slate matrix, southeast of Muncaster Mountain

10. Tectonic lenses of sandstone in phyllite, southwest side Mount Barnes .

11. Small blocks of sandstone in slate, east of Mount Christie

12. Disrupted beds and tectonic lenses in slate, west side Mount Olympus _.

13. Recumbent fold juxtaposed by faulting with inclined fold, northwest of Grand Pass

14. Sharply hinged fold in sandstone with slate interbeds, northeast shoulder McCartney Peak _........... 12

15. Fold with rounded hinge in sandstone with siltstone laminations, north side Mount Cameron

16. Sketch showing folded isoclinal fold northwest of Mount Olympus _

17. Large overturned drag fold on Mount Anderson

18-23. Photographs showing:

18. Folds in cleavage, phyllite, south ridge Mount Norton

19. Pencil structures in limestone northeast of Grand Pass _.

20. Pencil structures in slate, northwest McCartney Peak

21. Large pencils in slate and siltstone at high angle to bedding and fold axis, north of Mount Cameron ........ 15

22. Crude pencils parallel to axial plane of fold northeast of Grand Pass

23. Lineated granule conglomerate, east of Ludden Peak

24-32. Sketches showing:

24. Pencil lineations in the eastern core

25. Domains and subdomains eastern core

26. Principal structural elements for each subdomain

27. Development of eastern core by folding, faulting, and shear folding

28. Ninety-five poles to bedding in volcanic rocks in the Crescent Formation

29. Summary diagrams, structural elements in Domain West . .

30. Summary diagrams, structural elements in Domain East

31. Intersection of principal shear cleavage, late stage deformation with girdle of early fold axes and constructed kinematic axis . .

32. Generalized section through Olympic Mountains at plate margin

33. Computer form for structural data. . .

34. Computer output for structural program 


\section{TABLES}




\title{
THE STRUCTURE OF THE OLYMPIC MOUNTAINS, WASHINGTON- ANALYSIS OF A SUBDUCTION ZONE
}

\author{
By R. W. TABOR and W. M. CADY
}

\begin{abstract}
Long thin packets of structurally disrupted rocks in the eastern core of the Olympic Mountains mostly top eastward, but the overall age of the rocks decreases westward, suggesting early folding around subhorizontal axes with imbricate thrusting or imbricate thrusting alone.

Continued east-west compression overturned beds eastward, bending the packets into an arc within the horseshoe bend of the Crescent Formation, a foldlike structure that formed as the core rocks were imbricated or was extant from the original arcuate distribution of basaltic seamounts. In the western part of the eastern core, secondary structures (B elements) (mostly small-scale folds) developed parallel to the steep axis of the fold of the basaltic horseshoe; in the southern part of the core, the rock packets were sheared off beneath the basalts on the south limb of the horseshoe bend. Later shear folding on a cleavage fan oriented parallel to a north-northwesttrending subhorizontal kinematic axis rotated B elements (folds) formed earlier, producing widespread late pencil structures, in part centripetal to the basaltic horseshoe, where the late cleavage intersected earlier deformed bedding and cleavage. This late folding produced a domelike structure extended asymmetrically eastward.

The complex structure of the core rocks is consistent with current models of accretionary prisms in subduction zones and developed its form as the thick mass of volcanic rocks of the Crescent Formation to the east resisted the eastward movement of the accreted sedimentary prism.
\end{abstract}

\section{INTRODUCTION}

The marked horseshoe outcrop pattern of the Eocene basalts on the Olympic Peninsula has long fascinated geologists. Weaver (1937, pl. 2) was the first to recognize this pattern; in his interpretation, the peninsula was traversed by a large east-southeast-trending anticline, a concept that has persisted to the present. The rocks in the core of this fold were thought to be mostly pre-Tertiary (Weaver, 1937, p. 17-18), probably Cretaceous (Danner, 1955, p. 24-27). The structural complexity of the mountainous core became apparent as small areas were investigated in detail (compare McMichael, 1946; Danner, 1948; Harvey, 1959; Lindquist, 1961; Hawkins, 1967; Miller, 1967). Park (1950) and Walter Warren (written commun., 1955) cited evidence that core rocks included younger strata and anticipated some of the structural complexities described here.
We began systematic mapping of the mountainous core in 1961 (Cady, Tabor, MacLeod, and Sorenson, 1972; Cady, Sorenson, and McLeod, 1972; Tabor and others, 1972; Tabor, 1975; Tabor and Cady, 1978). Our study and unpublished work of the U.S. Geological Survey done earlier by Walter Warren, Charles Park, and others indicates that: the mountainous core of the range is mostly, if not all, Tertiary in age; much of the core is about the same age or younger than the partly encircling Eocene basalts; the rocks are highly deformed, having been thickened by imbricate faulting, and, in the eastern part, underwent multiple shear folding. Deformation probably took place in an accretionary prism during underthrusting of the continent by an oceanic plate.

In this report we describe and analyze the megascopic and macroscopic structures in homogeneous domains and subdomains of the mountainous core and develop a tectonic model for their formation.

\section{SUMMARY OF REGIONAL GEOLOGY}

Two major geologic terranes dominate the Olympic Peninsula. Surrounding the mountainous core on three sides is a horseshoelike belt of early and middle Eocene, mostly oceanic, basalt, the Crescent Formation of Brown, Gower and Snavely (1960, fig. 1). Overlying the basalt on the north, east, and south are upper Eocene to Miocene and minor Pliocene marine sedimentary rocks. The peripheral sedimentary rocks are fossiliferous and, though folded and faulted, are in general stratigraphically continuous. Within the arms of the basaltic horseshoe, the core consists of two major terranes. The western core of Eocene to Miocene rocks is nonslaty and at least locally includes coherent areas of rocks that are for the most part stratigraphically continuous. Complex folds and faults are common, and some areas are so totally disrupted that the rocks have the aspect of melange (Weissenborn and Snavely, 1968, p. F8-F9; Koch, 1968; Stewart, 1970; Rau, 1973, 1975; Tabor and Cady, 1978).

The slaty rocks of the eastern core are Eocene to 

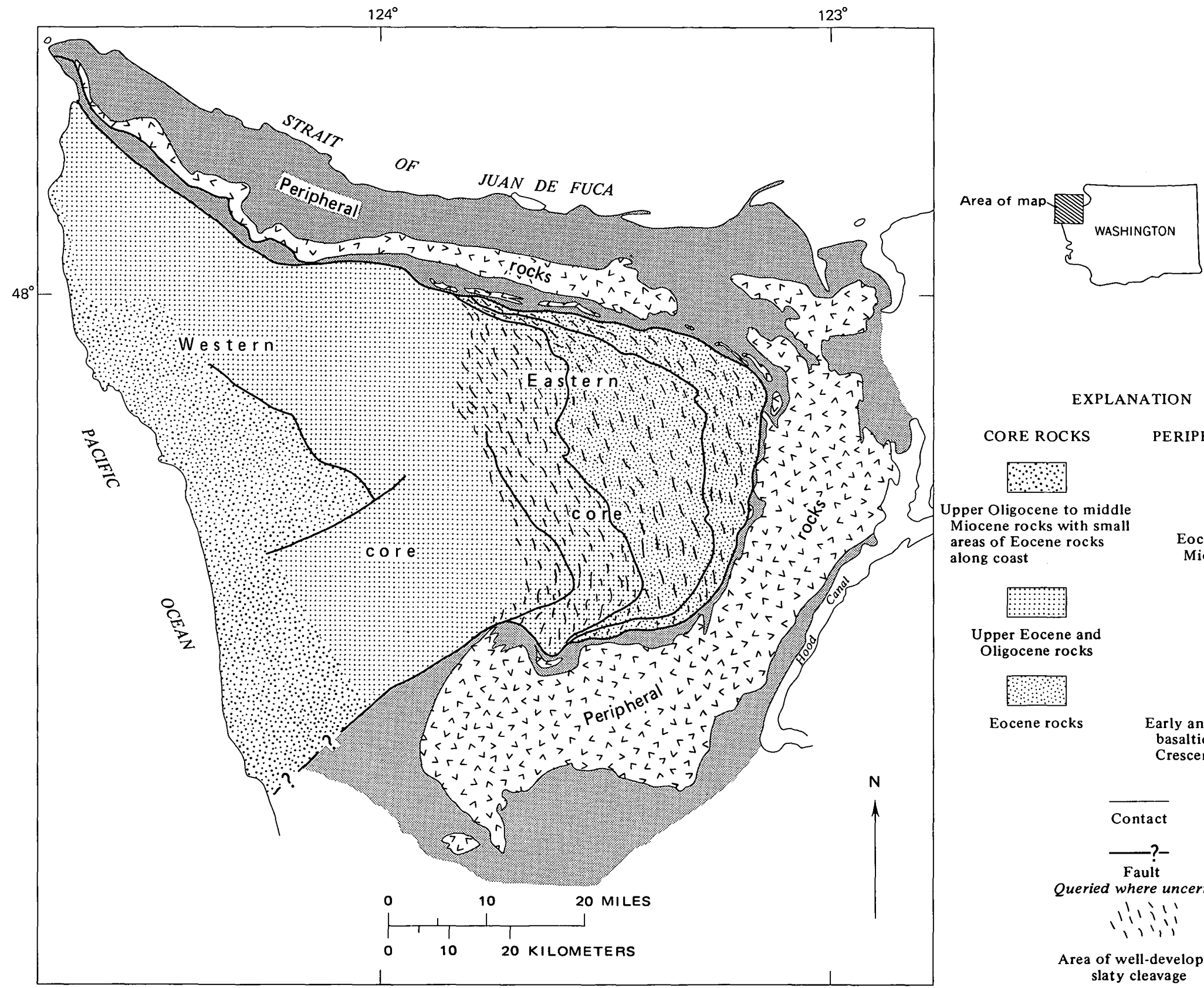

$\overline{\text { Contact }}$

Upper Oligocene to middle

Miocene rocks with sma

areas of Eoc
along coast

EXPLANA TION

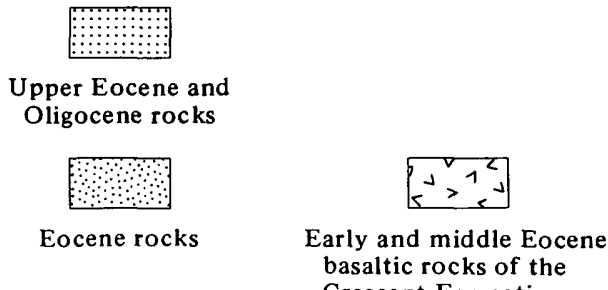

basaltic rocks of the

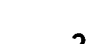

Fault

Queried where uncertain

$1 ! \vdots \vdots \vdots$

Area of well-developed slaty cleavage

Figure 1.-Major geologic terranes of the Olympic Peninsula. 
early Oligocene in age. They are pervasively sheared and best characterized as broken formation in the terminology of Hsü (1968, p. 1065-1066). At many places, the rocks resemble melanges described in the Franciscan rocks of California (Page, 1966, p. 260; Hsü, 1969; Suppe, 1973, p. 17-22; Cowan, 1974, p. 1625-1628), but the Olympic core rocks lack blocks of recognizable exotic material. And there are no blueschists or eclogites. Although there are a few small feldspathic peridotite dikes, no mantle material has been recognized. Nevertheless, because of the oceanic basalt and the structural complexity, numerous workers have suggested that the Olympic core rocks were emplaced during subduction of oceanic lithosphere (Stewart, 1970, p. 66; 1971, p. 201; McKee, 1972, p. 166-169; Rau, 1973, p. 10-11; Glassley, 1974, p. 792-793; Snavely and Pearl, 1975; Tabor, 1975, p. 33-36; Cady, 1975, p. 578-581; Cheney and Stewart, 1975; Tabor and Cady, 1978).

This report is focused on the slaty rocks of the eastern core. One might question whether conventional structural analysis techniques can be applied to melange or broken formation where shearing may have destroyed any order or symmetry commonly displayed by folded beds. As we will show, although the imprint of shearing is dominant everywhere in the eastern core, the tectonic fabric has considerable order and symmetry.

\section{PROCEDURE AND ACKNOWLEDGMENTS}

We collected most of the structural data used in this analysis between 1961 and 1972. The Mount Angeles, Tyler Peak, and The Brothers quadrangles and local smaller areas such as the region north of Staircase (fig. 2) have more data than the remaining area, which was mapped in reconnaissance fashion.

Data was stored on punch cards and plotted in projection on the lower hemisphere of an equal-area net with the help of an IBM 360-65 computer (see section "Supplemental Information"). We thank G. K. Muecke and H. A. K. Charlesworth, of the University of Alberta, for giving us their structural plotting program (see Muecke and Charlesworth, 1966). We combined their program with a storage and retrieval program designed and operated with the help of computer programmer Ming Ko and other specialists of the U.S.G.S. computer facility.

We thank the following workers for considerable help in collecting the structual data in the field: John Alan Bartow (1965), Wyatt Gilbert (1965), Robert Koeppen (1972), Norman MacLeod (1961-62), Kenneth Pisciotto (1971), Eduardo Rodriguez (1972), Martin Sorensen (1964-68), Richard Stewart (1967-71), Robert Tallyn (1969-70), and Robert Yeats (1968-69).
We have spent many hours discussing Olympic structure with our colleagues, in particular William Glassley, Norman MacLeod, Parke D. Snavely, Jr., Richard J. Stewart, and Robert Yeats. M. Clark Blake, Jr., Richard J. Stewart, and Parke D. Snavely, Jr., made many helpful suggestions. We are particularly indebted to Ronald Kistler and Robert Loney for considerable and patient guidance in the structural analysis.

\section{STRUCTURAL GEOLOGY OF THE EASTERN CORE}

\section{OVERVIEW OF THE STRUCTURE}

\section{MAJOR ROCK UNITS}

The rocks of the eastern core are characterized by lithologic monotony and pervasive penetrative deformation. The rocks are mostly shale, siltstone, and sandstone, but have in minor amounts conglomerate, basalt, basaltic volcaniclastic rock, diabase, and gabbro. The sedimentary rocks have been variously metamorphosed to slate, semischist, and phyllite, mostly in the pumpellyite, prehnite-pumpellyite, and low-rank greenschist facies of regional metamorphism. Basaltic rocks are now greenstones or greenschists. Sandstones are mostly feldspathic to volcanic subquartzose sandstones (in the terminology of Crook, 1960). Graded beds, bottom structures, and rhythmic bedding suggest that the sandstones are turbidites.

Core units form long, irregular curved packets roughly convex eastward (fig. 2). They vary from relatively intact interbedded sandstone and slate to completely disrupted broken formations of foliate sandstone or semischist in a matrix of slate or phyllite. Although we mapped most unit boundaries on the basis of lithology, units are separated locally by wide zones of intensely sheared rock. In places, faulting is clearly indicated by truncation of folds in the sandstone of one unit by slate of an adjoining unit (see Tabor and others, 1972). Because of these relations and the ages based on fossils (see below), we mapped major faults at the boundaries of the major units. Probably there are many more faults than shown.

The four major structural units of the eastern core are the Needles-Gray Wolf lithic assemblage, the Grand Valley lithic assemblage, the Elwha lithic assemblage, and the western Olympic lithic assemblage (fig. 2; Tabor and Cady, 1978). Fossils are very sparse in the eastern core; probable ages based on fossils are summarized in table 1. Because the units are broken formations and some fossils are in probable tectonic blocks, we do not know whether the rocks containing the fossils have moved long distances tectonically into the units in which they are now found. A few have not 

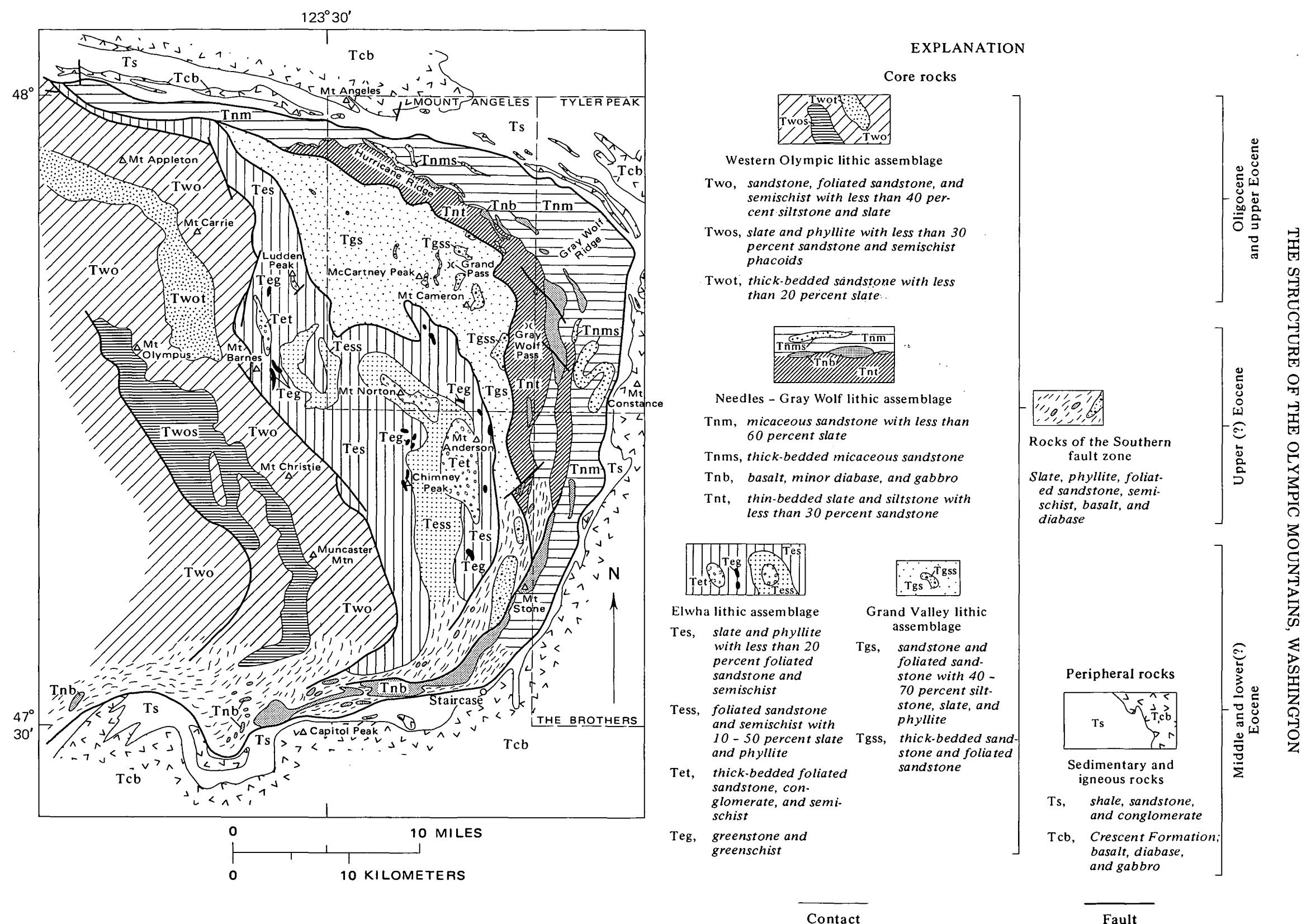

FigURE 2.-Geologic map of the eastern core. 
TABLE 1.-Probable ages of units in the eastern core and adjacent peripheral rocks on the Olympic Peninsula

\begin{tabular}{|c|c|c|}
\hline Unit & Age & Fossil evidence and reference \\
\hline \multicolumn{3}{|c|}{ Peripheral units } \\
\hline $\begin{array}{l}\text { Crescent Formation } \\
\text { and associated } \\
\text { sedimentary rocks. }\end{array}$ & $\begin{array}{l}\text { Early and } \\
\text { middle Eocene } \\
\text { and possibly } \\
\text { late Eocene. }\end{array}$ & $\begin{array}{l}\text { Many microfossils, some megafossils, } \\
\text { coccoliths (Rau, 1964, p.G3-G4; } \\
\text { Tabor and others, 1972; Cady, } \\
\text { 1972; P.D. Snavely, Jr., N.S. MacLeod, } \\
\text { and J.E. Pearl, written commun., 1974). }\end{array}$ \\
\hline \multicolumn{3}{|c|}{ Core units } \\
\hline $\begin{array}{l}\text { Needles-Gray Wolf } \\
\text { lithic assemblage. }\end{array}$ & Late Eocene ...... & $\begin{array}{l}\text { Some microfossils, a few megafossils } \\
\text { (Cady and MacLeod, 1963; Cady, Tabor, } \\
\text { MacLeod and Sorenson, 1972). }\end{array}$ \\
\hline $\begin{array}{l}\text { Grand Valley } \\
\text { lithic assemblage. } \\
\text { Elwha lithic }\end{array}$ & Early and middle & $\begin{array}{l}\text { Very sparse microfossils (Tabor and } \\
\text { others, 1972). } \\
\text { Very sparse microfossils (Tabor and }\end{array}$ \\
\hline $\begin{array}{l}\text { assemblage. } \\
\text { Western Olympic } \\
\text { lithic assemblage. }\end{array}$ & $\begin{array}{l}\text { Eocene. } \\
\text { Late Eocene to } \\
\text { early Oligocene. }\end{array}$ & $\begin{array}{l}\text { others, 1972). } \\
\text { Lithologic continuity with fossilif. } \\
\text { erous rocks to west and northwest } \\
\text { (Gower, 1960; R.J. Stewart, written } \\
\text { commun., 1970; Harvey, 1959, } \\
\text { P. 45-46; P.D. Snavely, Jr., } \\
\text {..S. MacLeod, and J.E. Pearl, written } \\
\text { commun., 1974). }\end{array}$ \\
\hline
\end{tabular}

moved far, for the general lithology of the surrounding terrane is the same as that of local rocks containing the fossils.

On the basis of whole-rock potassium-argon ages, regional metamorphism culminated in the growth of new minerals about 29 million years ago. A later episode of fault brecciation and quartz veining (along faults during uplift?) took place about 17 million years ago (Tabor, 1972).

\section{FAULTS BOUNDING THE CORE}

The highly disrupted core rocks appear to be separated from the peripheral rocks by anastomosing steeply dipping faults that we interpret to be thrust faults (figs. 2,3). Some of these faults are between units of contrasting rock types; one such fault, the Hurricane Ridge fault, separates micaceous lithic to feldspathic subquartzose sandstone of the NeedlesGray Wolf lithic assemblage in the core from volcanicrich lithic subquartzose sandstone associated with the Crescent Formation. Shearing associated with the Hurricane Ridge fault is well exposed on the Hurricane Ridge Road (fig. 4), on Mueller Creek northeast of Gray Wolf Ridge, and along a logging road up Boulder Creek east of Mount Stone. An unnamed westward extension of the Hurricane Ridge fault separates the Crescent Formation from relatively undeformed sandstone and shale north of the western core. This extension is a moderately dipping thrust fault that has moved the Crescent Formation over younger sedimentary rocks similar to peripheral rocks that lie stratigraphically above the Crescent Formation to the north (P. D. Snavely, Jr., N. S. Macleod and J. E. Pearl, written commun., 1972).
The continuation of the Hurricane Ridge fault in the southern Olympic Mountains separates rocks of less contrasting lithology. Mica is common in both peripheral sedimentary rocks and in core units (Tabor and Cady, 1978), but the fault can be traced along slaty tectonic-breccia zones such as in Slate Creek near Staircase and northwest of Capitol Peak, near the head of the Wynoochee River. Most of the rocks in the southeastern core area are intensely sheared; neither core units nor bounding faults can be traced far in them. To the south near Lake Quinault, the faults that bound the core units probably merge through this zone of intense deformations to form a fault zone at the base of the peripheral rocks (fig. 3 ).

The southern fault zone is critical to the interpretation of structure here. The faults shown on the map tend to truncate southeast- to south-trending structures and lithologic units. This tendency is especially evident west of Mount Stone (fig. 2), where a prominent shear zone northwest of the high basalt ridge forming Mount Stone and other peaks truncates major core units. On the northern side of the core, where units and structures tend to curve around parallel to the peripheral basaltic horseshoe, the recognition of tectonic truncation is more difficult, except farther west where fossils are more abundant.

The extension of faulting southwest of Lake Quinault is speculative because the area is completely covered by glacial deposits. By analogy to the faulted contact between the: highly deformed core rocks and the less deformed peripheral rocks elsewhere and interpretation of drill-core data and aeromagnetic surveys (P. D. Snavely, written commun., 1976), a fault or complex of faults probably extends southwestward to the coast.

The Calawah fault zone (Gower, 1960) along the north margin of the western core cuts only core rocks where it is best exposed east of Sappho as a wide zone of sheared argillite set with many blocks of sandstone, conglomerate, and basaltic volcanic rocks. Westward from near Sappho, the probable extension of the Calawah fault separates highly deformed core rocks from peripheral rocks (P. D. Snavely, Jr., N. S. MacLeod, and J. E. Pearl, written commun., 1974). Eastward, the Calawah fault appears to splay to the southeast into several faults separating the slaty units of the eastern core.

\section{SIGNIFICANCE OF TOP DIRECTIONS}

Of great significance to the structural interpretation of the Olympic Mountains is the distribution of bedding tops. In the peripheral rocks, sedimentary beds and the pillow basalts of the Crescent Formation generally top away from the core, although locally there 


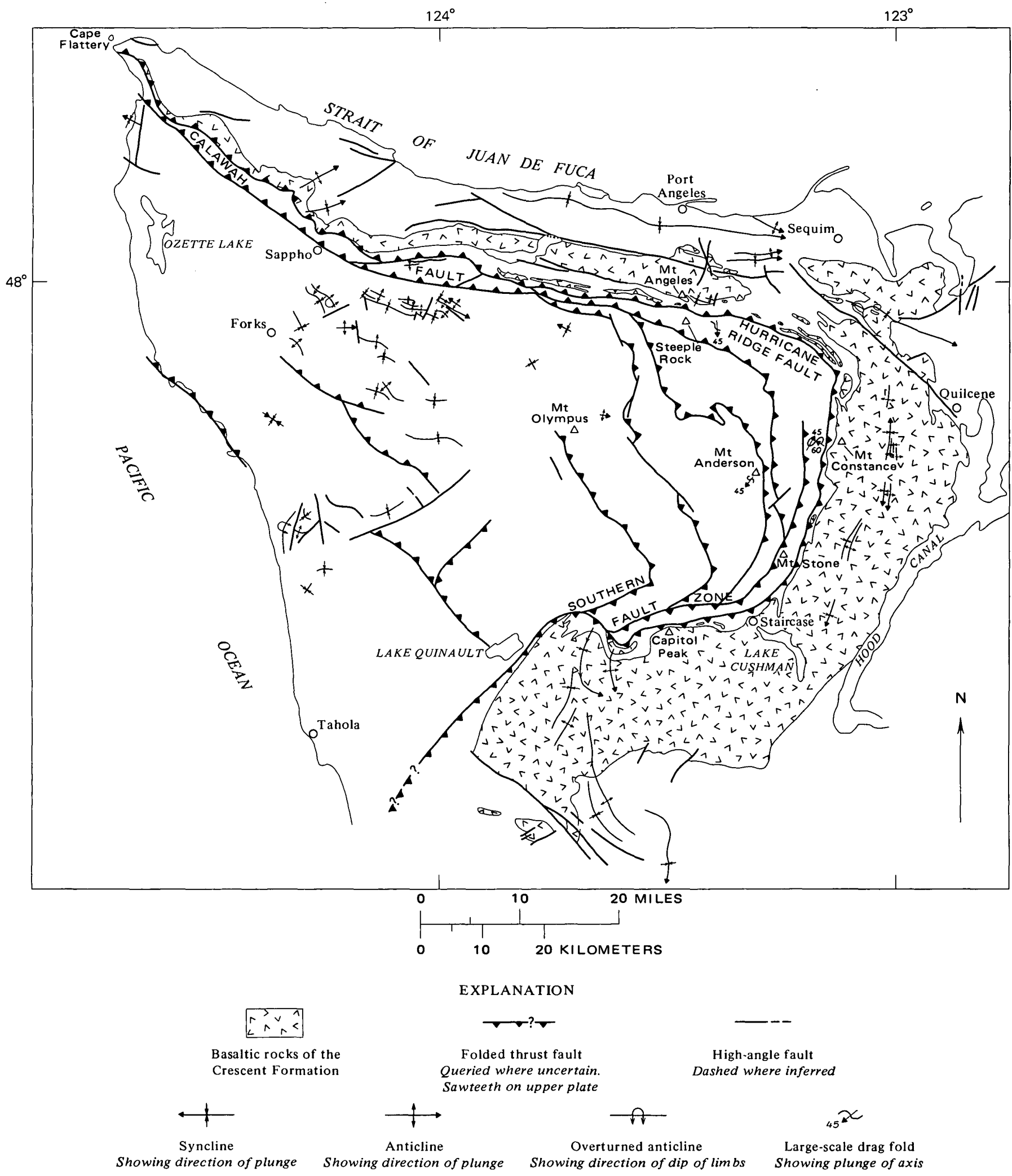

Figure 3.-Major folds and faults on the Olympic Peninsula. Geology modified from Tabor and Cady (1978). 


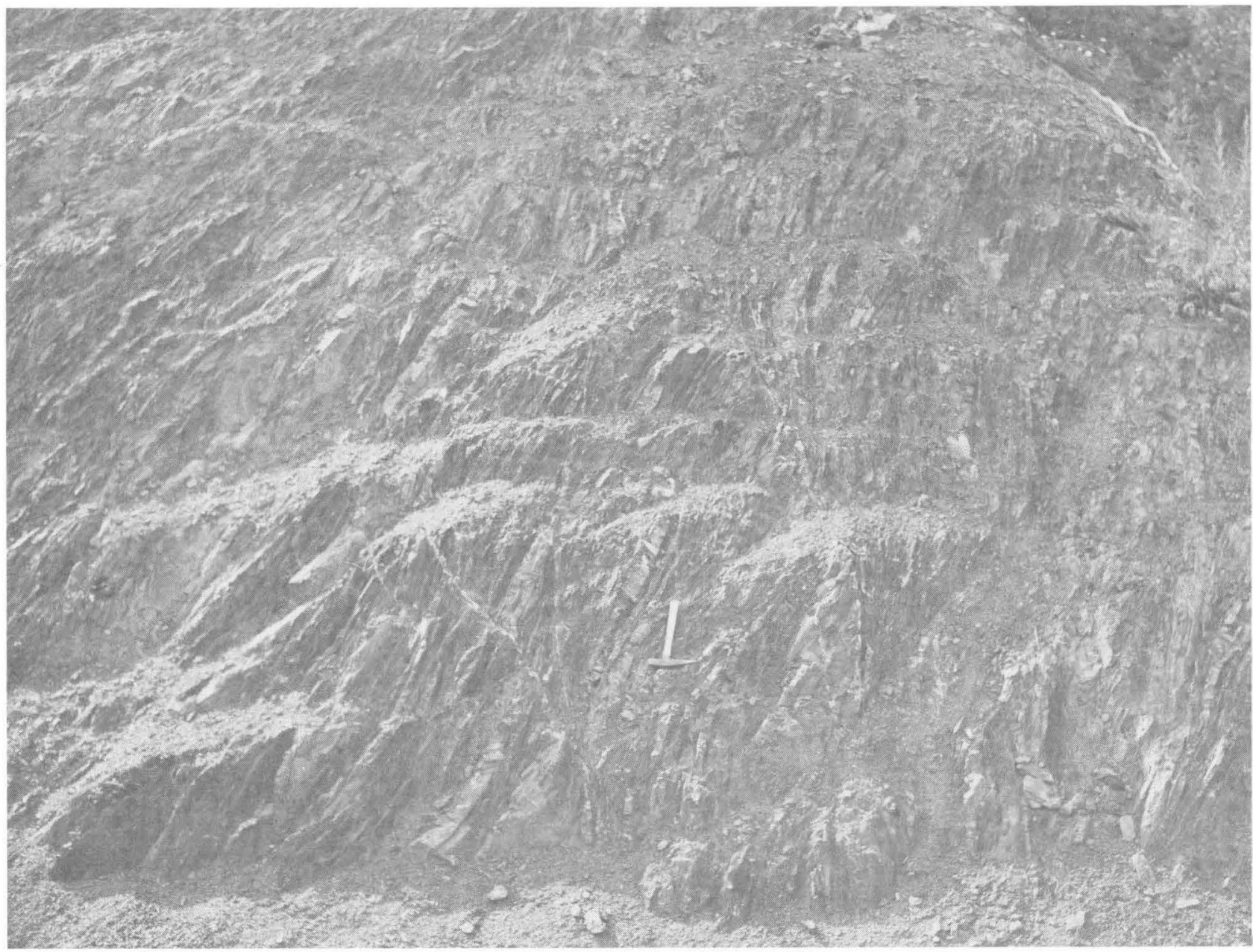

FIGURE 4.-Beds sheared off by weakly developed cleavage in zone of disruption marking the Hurricane Ridge fault zone, Hurricane Ridge Road, south of Mount Angeles.

are a few folds (fig. 3). Within the rocks of the eastern core, about 23 percent of the beds measured yielded top data such as graded beds, ripple marks, load casts, and pillows in basalt. Of the known tops, about 70 percent face north, east, and southeastward, away from the core. If each lithic assemblage or structural unit is considered separately, about the same proportion of tops faces away from the core. This suggests that the core rocks are older coreward or westward, but the best paleontologic evidence indicates that in general the rocks are as young or younger westward and axially to the horseshoe, with one possible age reversal in the Elwha lithic assemblage (table 1). This enigmatic relation supports the interpretation that the major rock units are separated by faults (Tabor and others, 1970), as indicated by the penetrative deformation within the units and local severe disruption at their margins.

\section{TECTONIC VERSUS SOFT-SEDIMENT SLUMP STRUCTURES}

Many of the structures of highly disrupted beds found in rocks of the Olympic core could have originated through soft-sediment slumping. We did not find specific evidence to identify olistrostromes, although it is likely that they were common in the original depositional environment. The slaty cleavage and recrystallization, closely associated with the folding, indicate that most of the structures in the eastern core are closely related to the metamorphism of the core rocks and are therefore tectonic.

\section{TECTONIC FABRIC}

CLEAVAGE

Cleavage is the dominant structural element of the 
eastern core. It is less pronounced in rocks of the northeastern part, where bedding is relatively consistent and continuous; southwestward, beds are increasingly disrupted by cleavage. In the most disrupted areas, bedding and other sedimentary features are preserved in isolated blocks in the sheared matrix of slate and siltstone (fig. 5).

We have not made a distinction between shear cleavage and fracture cleavage in this analysis, but most cleavage is parallel to axial planes of folds (fig. 6) and many folds are highly attenuated.

The hinges of folds are commonly sheared off by movement along cleavage (fig. 7), and, in some areas, thin beds of sandstone are alined in a crisscross pattern (fig. 8A), suggesting that all hinges have been sheared off; the beds are realined roughly parallel to the cleavage. Sandstone lenses and large blocks of thinly bedded sandstone and slate may display divergent beds or folded beds, truncated by the cleavage in slate or phyllite enveloping the sandstone (figs. $6,8 B$ ) or folds and beds may be in total chaos (fig. $8 C$ ).

The scale of disruption of bedding by movement along cleavage ranges from outcrop dimensions (figs. 9, 10,11 ) to entire mountainsides (figs. 5, 12), although its prominence may well be dependent on the bedding and lithologic features of the original rocks. In outcrops of slate, where bedding is visible in siltstone laminations, isoclinal folding is commonly evident, and the beds are not disrupted on an outcrop scale. In very thick beds of sandstone and slate, disruption is recog-

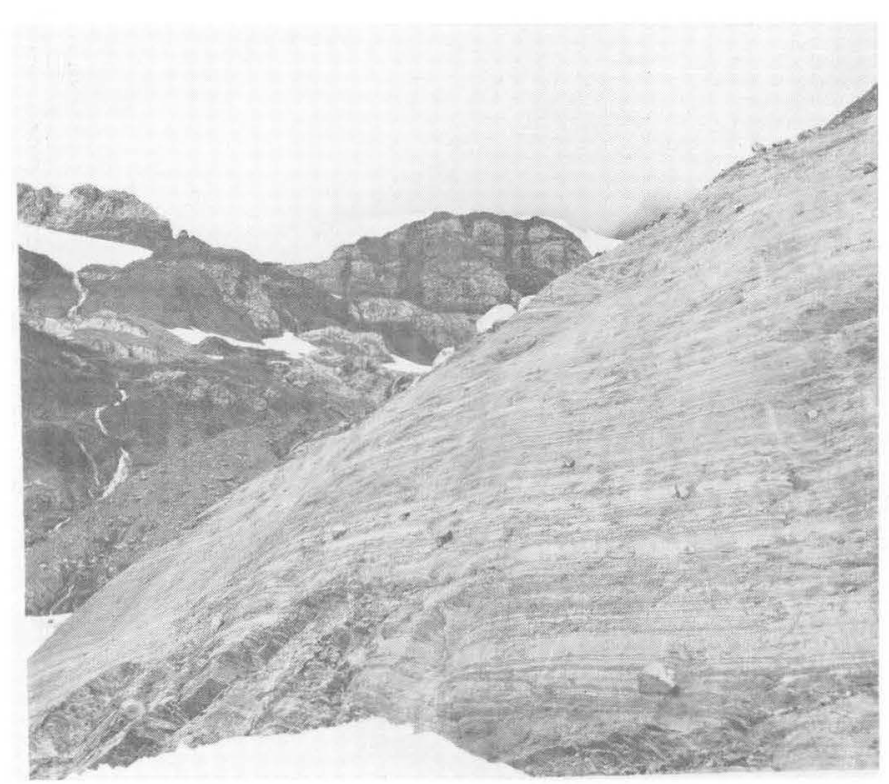

FIGURE 5.-Block of undisrupted thin-bedded sandstone and slate (foreground) in broken formation in the western Olympic lithic assemblage. Tightly appressed isoclinal folds are found in some thin-bedded blocks like this one. Subdomain 17, southwest side of Mount Olympus. nizable only at map scale (fig. 2). The most severe disruption is found in thinly bedded sandstone and slate where each outcrop bears many small tectonic lenses (compare fig. 11). Where the rock is strongly sheared, it is commonly crisscrossed by many curving cleavages and studded with blocks and lenses (fig. 9).

Whereas pelitic rocks through the area of this study display fairly well developed slaty cleavage, the cleav-

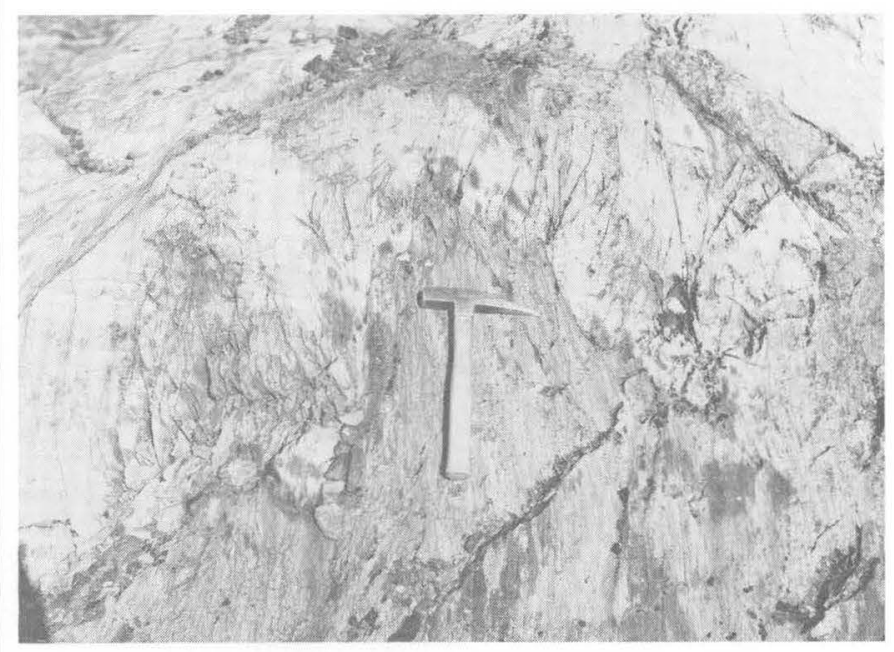

Figure 6.-Shear fold in thin-bedded sandstone with slate core. Axial-plane cleavage is alined with hammer handle. Note divergence of bedding and cleavage in sandstone and irregular shape of fold. Subdomain 17, southwest of Mount Olympus, upper South Fork of the Hoh River.

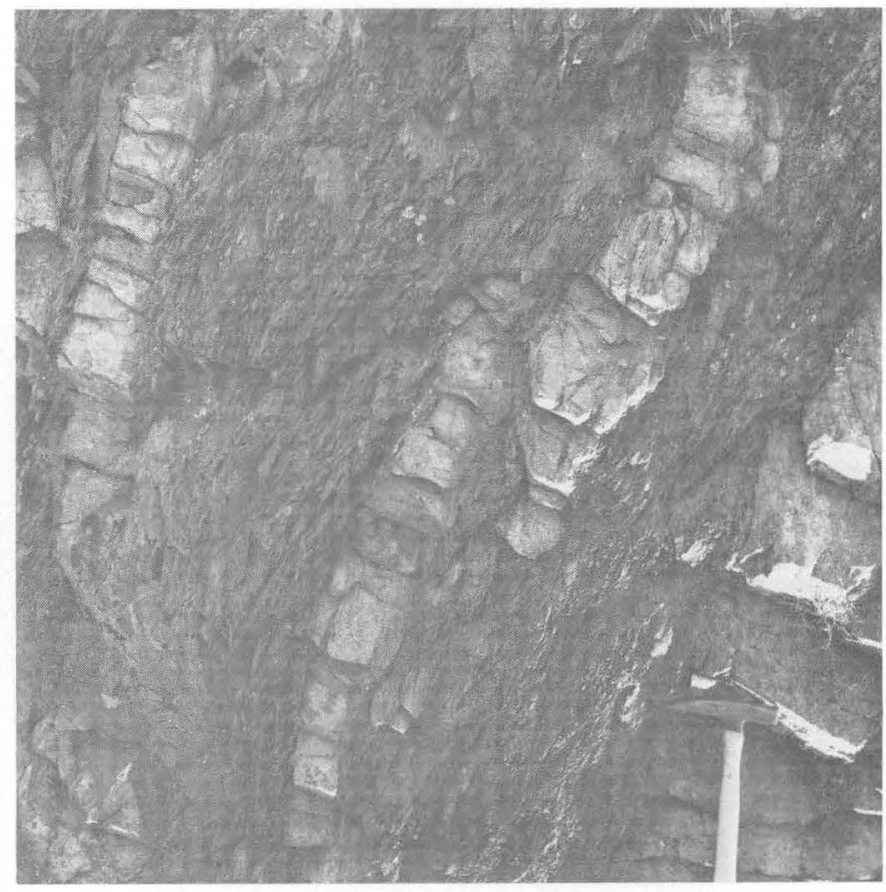

Figure 7.-Sheared-off sandstone bed in weakly developed slate. The structure probably began as a clockwise drag fold. North of subdomain 16, south side of Mount Appleton. 
age in sandstone is more subtle. Development of cleavage or low-rank schistosity in sandstones, as in other rocks, progresses from northeast to southwest, mostly independent of the units mapped (fig. 2). The most highly schistose and more recrystallized rocks occur in the south-central part of the area in subdo-

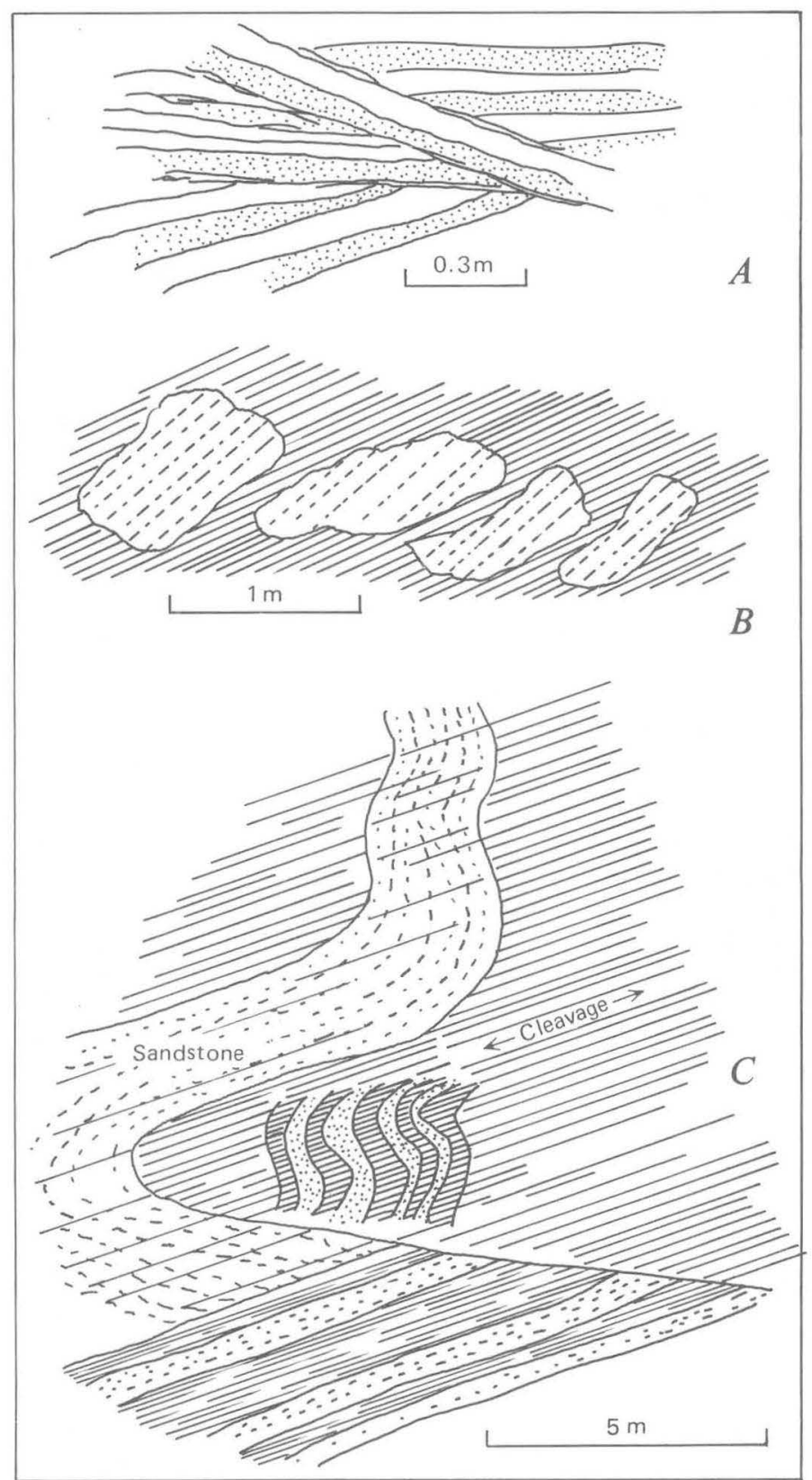

Figure 8.-Notebook sketches of disrupted beds in sandstone and slate. $A$, Crisscross beds in thin-bedded slate; folded beds sheared off and juxtaposed. Subdomain 6 , north side of Hurricane Ridge. $B$, Sandstone blocks and lenses in slate with bedding partially rearranged by movement along cleavage. Subdomain 10, northwest of Mount Anderson. C, Parts of folds and beds juxtaposed by movement along slaty cleavage. Subdomain 14, east side of Chimney Peak. mains 8 and 10 and the northern parts of subdomains 13 and 14 (see fig. 25).

The development of cleavage (schistosity) and new minerals in sandstones can be best seen in thin section.

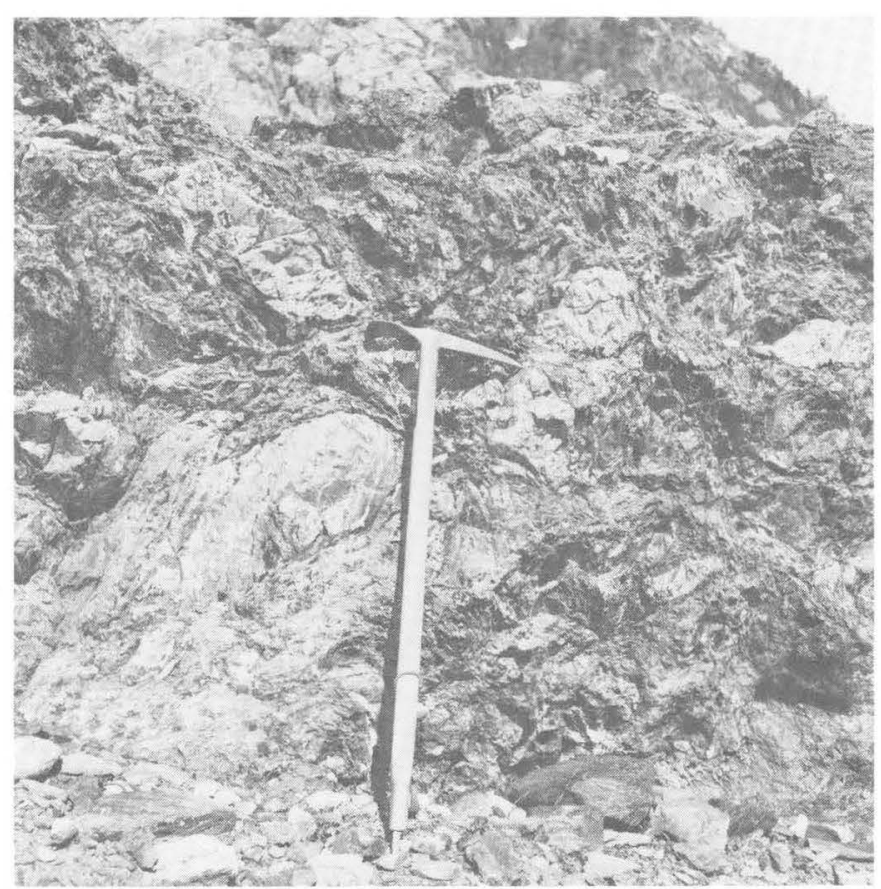

Figure 9.-Highly disrupted zone with blocks and lenses of sandstone in contorted slate matrix. Subdomain 13, southeast of Muncaster Mountain.

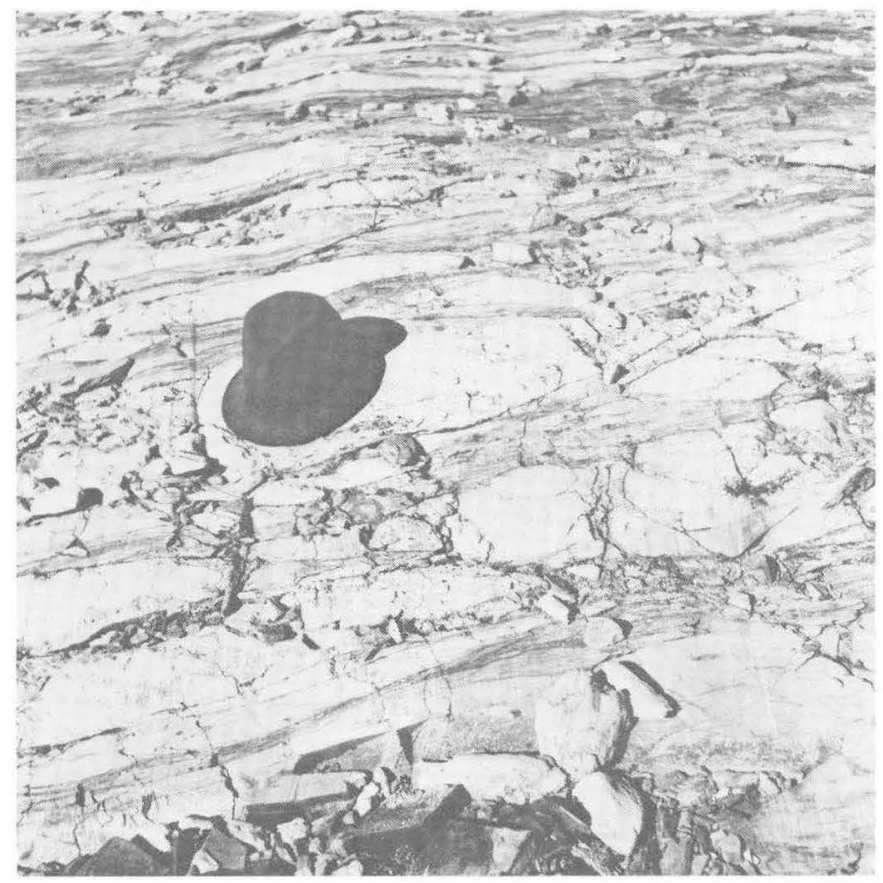

Figure 10.-Tectonic lenses of sandstone in phyllite. Subdomain 8, southwest side of Mount Barnes. 
In the initial stages of metamorphism (or diagenesis), clastic irregular haloes and wisps of white mica and chlorite grow around grains of quartz and feldspar. Where penetrative deformation increases, the interstitial micas are smeared out into thin layers anastomosing between lithic fragments and microaugen of quartz and feldspar. Lithic fragments and plagioclase are replaced more and more by white mica (and calcite and chlorite). Clastic grains are crushed and lose their identity. As deformation and recrystallization progressed, the micas apparently became more abundant and both quartz and mica more segregated. In the most metamorphosed sandstones, the semischists, a schistose mica fabric prevails with rare augen of quartz and plagioclase-bearing relict clastic textures (see Tabor, 1972, p. 1812).

\section{FOLDS}

Folds of outcrop scale are common throughout the area, although hinges are hard to find and many folds are revealed only by opposing tops of beds. Folds in thinly bedded rocks most commonly have sharp hinges and are open to tightly appressed (figs. 13, 14). Fold hinges in thick-bedded sandstones are more rounded (fig. 15).

Pelitic material appears to have been highly mobile.

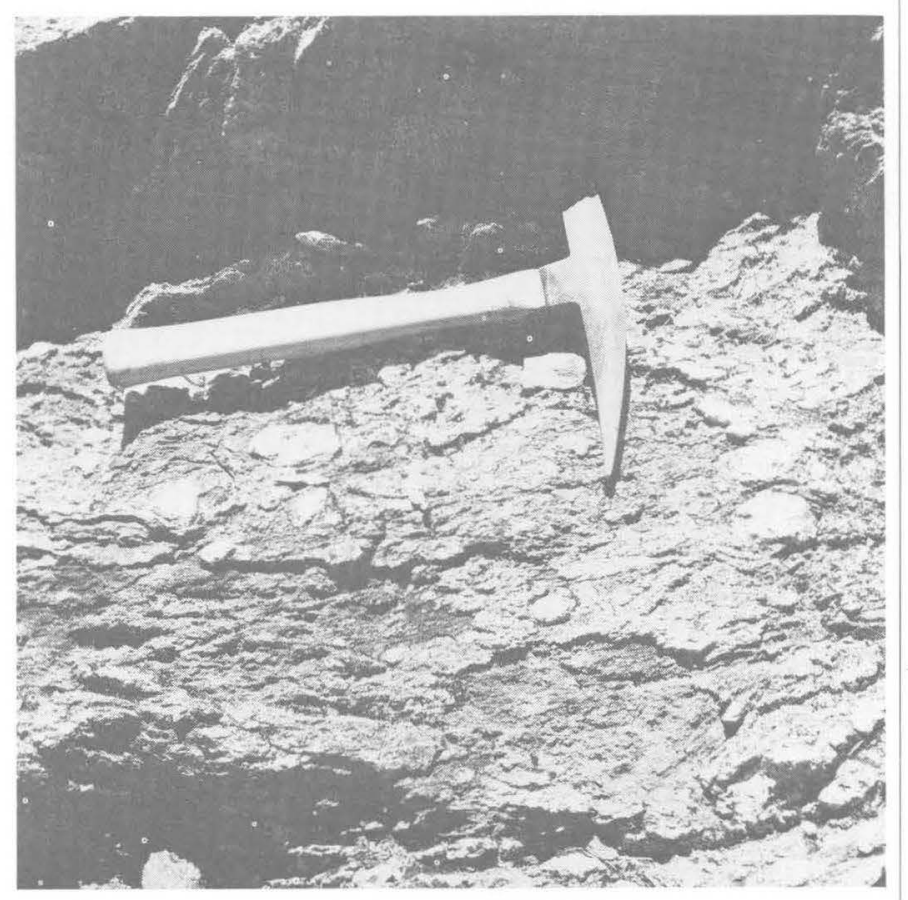

Figure 11.-Small tectonic blocks of sandstone in slate. The cleavage runs left to right and the rock has fractured parallel to a quartz vein (parallel to plane of photo) which has weathered differentially, leaving quartz caps on the sandstone clasts. Subdomain 14, east of Mount Christie, head of Buckinghorse Creek.
In folds with tightly appressed limbs, the core material is almost totally squeezed out. Folded folds are common (fig. 16), and the juxtaposition of fold hinges along shears (or small faults) make a chaotic terrane (fig. 13). The prevalence of axial-plane cleavage and flowage of material into the crest of similar folds indicates that most folding is shear folding.

Very few large folds greater than outcrop scale have been found in core rocks; they appear to be more common in peripheral rocks and in rocks of the western core (fig. 3). A large fold, of drag-fold form and measuring several kilometers across the limbs, crops out west of Mount Constance (fig. 2) in subdomain 12 (see section at end of text "Frequency Diagrams for Subdomains"); a poorly developed draglike fold lies east of Steeple Rock in subdomain 1, and a moderately large fold is exposed on the ridge of Mount Anderson (fig. 17). As very few individual folds or structures can be related to particular phases of folding by style or orientation, we do not know how these large-scale folds fit into the tectonic sequence. The shapes of the fold and steeply plunging axes suggest that they are simply large versions of the small folds.

Folds in cleavage are numerous in subdomains 8 and 10 (fig. 25) and southward. The larger cleavage folds are cylindrical and open (fig. 18). A later cleavage parallels axial planes of folds in the early cleavage. Small crinkle folds on cleavage surfaces are especially prominent in subdomain 10 . The fold axes of the crinkles tend to parallel larger fold axes in cleavages and pencil structures (see below and fig. 30). Locally crinkle folds are folded.

Conventional structural analysis depends heavily on field recognition of the relative ages of folds by their style, superposition, or orientation. We were unable to recognize various generations of folds or other structures by style. That the Olympic core rocks have been subjected to several episodes of folding is shown by crinkle folds, folds in cleavage, and a few isolated folded folds and by cleavage girdles, axial-place girdles, and fold-axis girdles in most plots of the structural elements (see section at end of text "Frequency Diagrams for Subdomains").

\section{PENCIL STRUCTURES}

The most eye-catching, consistently oriented, and characteristic structures in the eastern core of the Olympic Mountains are thin slivers of rock or pencils, formed by the intersections of either two or more cleavages or cleavage and bedding. The pencils range in length from a few centimeters to 1 or $2 \mathrm{~m}$ (figs. 19, 20,21 ). They are prominent in slate but also occur in sandstone, where they are blockier and less perfectly formed. 


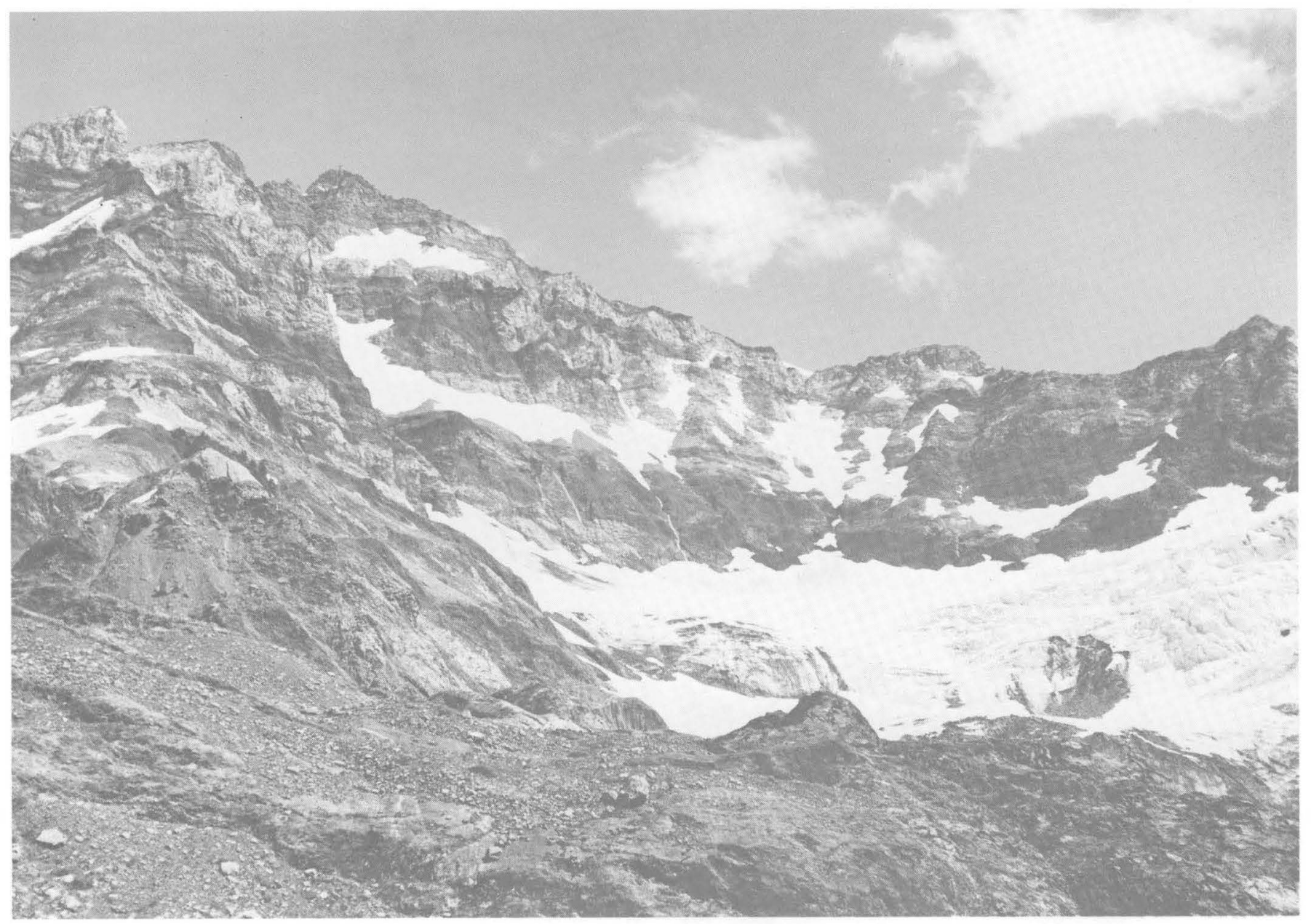

FIGURE 12.-Disrupted beds and tectonic lenses of sandstone in slate. Subdomain 17, west side of Mount Olympus.

In many outcrops, especially in the western and northeastern parts of the eastern core, pencil structures lie in the bedding; in the central part, especially where several generations of cleavage occur, pencils do not lie in bedding (figs. 19, 21, 22) but stand almost perpendicular to fold axes or the crests of folds. These pencils athwart fold axes are clearly formed by two cleavages and are probably later formed than their associated folds. Because of their consistent orientation (homogeneity) relative to other structures, pencils appear to be late-formed structures, but we observed a few outcrops where pencils are folded with the cleavage.

The orientations of pencils plotted in figure 24 are direct measurements of pencil bearings and plunge. We found that plotting intersecting cleavage and bedding, especially where they intersect in a small angle, gave unreliable pencil orientations. A small error in the measurement of two nearly parallel planes leads to a very large error in orientation of their intersection. The strong maximum of pencil orientations (fig. 30C) is produced partly by the large amount of data collected in the axial region of the eastern core where pencils are particularly well formed.

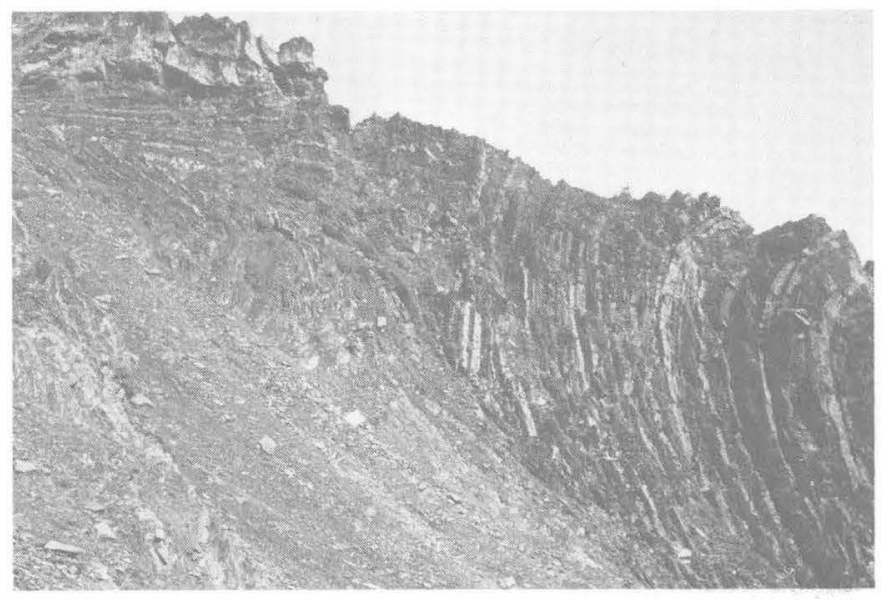

Figure 13.-Recumbent fold (left) juxtaposed by faulting with inclined fold (right). Subdomain 5, northwest of Grand Pass. 


\section{STRETCHED CLAST LINEATIONS}

In subdomains $3,8,9,10$, and 14 , foliated sandstones, especially those of the Elwha lithic assemblage, commonly show a strong linear fabric of uniformly distributed slate chips, 1-2 mm long. Foliated granule conglomerates display a similar lineation (fig. 23). These lineations tend to parallel pencils (fig. 30C) in the same area.

\section{MAJOR STRUCTURAL TERRANES}

We selected two major structural domains and 19 subdomains (fig. 25) on the basis of pencil orientation because it is the most consistent structural element (fig. 24). Although some of the subdomains roughly coincide with the major core units, most are unrecognizable in the field. The boundary between the principal domains, Domain West and Domain East, is recognizable in the field by opposing dips and plunges.

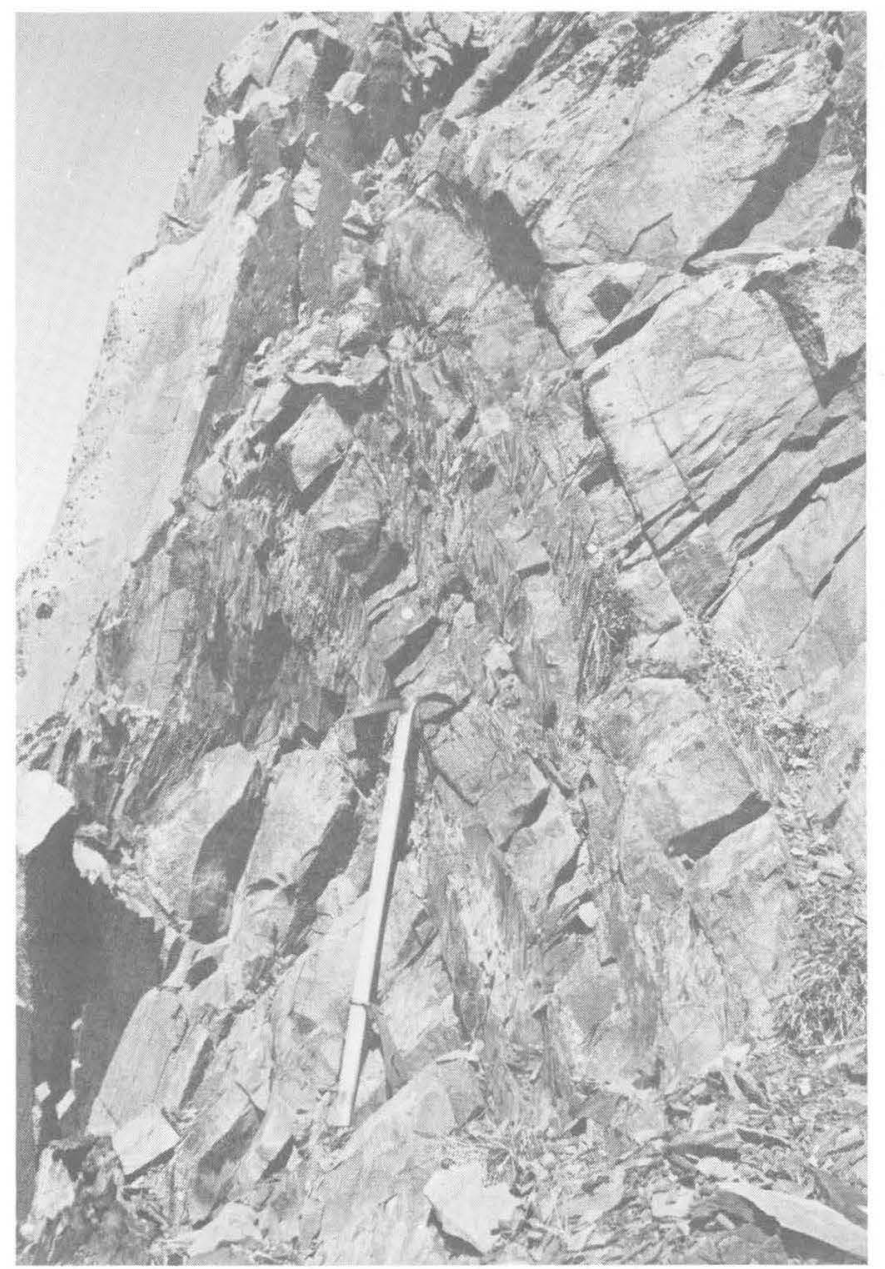

FIGURE 14.-Sharply hinged fold in thick-bedded sandstone with thin slate interbeds. Axial plane cleavage and a second cleavage form pencil structure in the slate beds. Subdomain 5, northeast shoulder of McCartney Peak.

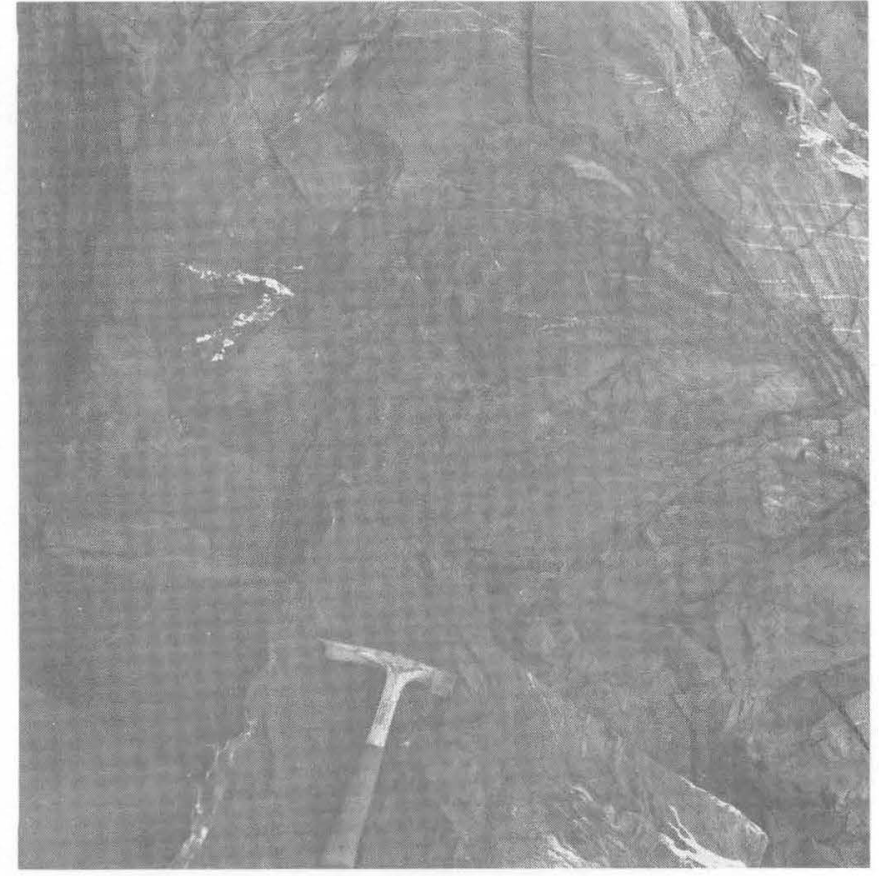

Figure 15.-Fold with rounded hinge in sandstone with dark siltstone laminations. Fold is partially sheared off along right limb. Subdomain 5, north side of Mount Cameron.

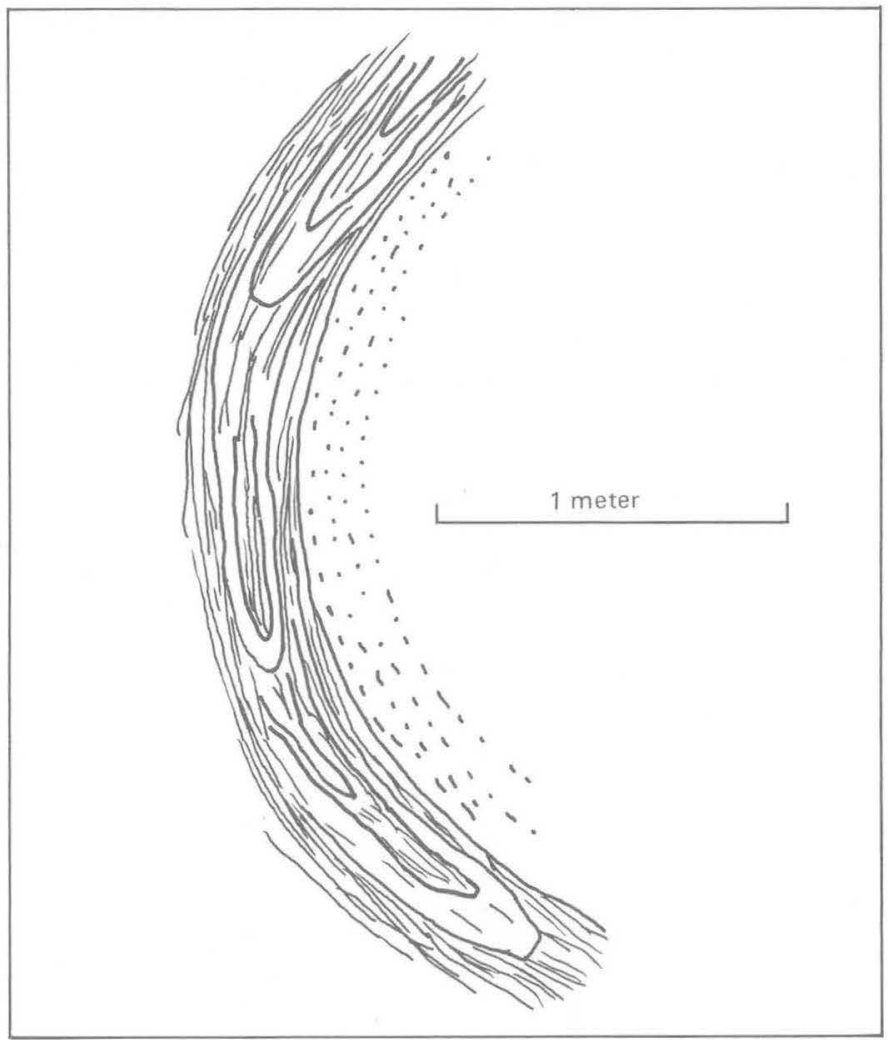

FIGURE 16.-Sketch of folded isoclinal fold in slate bed. Subdomain 16, northwest of Mount Olympus. 
Planar structures east of the boundary dip west and southwest, and most pencils plunge westward. In contrast, planar structures west of the boundary dip to the east and northeast, and pencils plunge eastward (fig. 26). Many structures along the boundary have steep to vertical dips. Pencils in subdomains 1 and 2 (east of the boundary) actually plunge south to southeast, but the direction of plunge rotates smoothly and becomes dominantly westward approaching the center of Domain East. Subdomains 16, 8, and 10 best illustrate the progressive change from east to west dip of bedding and cleavage and from east to west plunge of pencils and other linear structures.
Subdomains 1 and 2 extend beyond the core into the peripheral rocks. In subdomain 1 , only 18 percent of the data fall outside the core, and these are mostly bedding. In subdomain 2 , about 50 percent of the data come from the peripheral rocks; for that reason, we broke subdomain 2 into two small domains, $2 \mathrm{~A}$ and $2 \mathrm{~B}$, separated by the Hurricane Ridge fault. Except for cleavage, not present in most of the peripheral rocks in subdomain $2 \mathrm{~A}$, structural elements do not suggest that the peripheral rocks of this area have undergone a structural history highly different from the adjoining core rocks. As will be shown, the difference is mostly one of intensity of deformation.

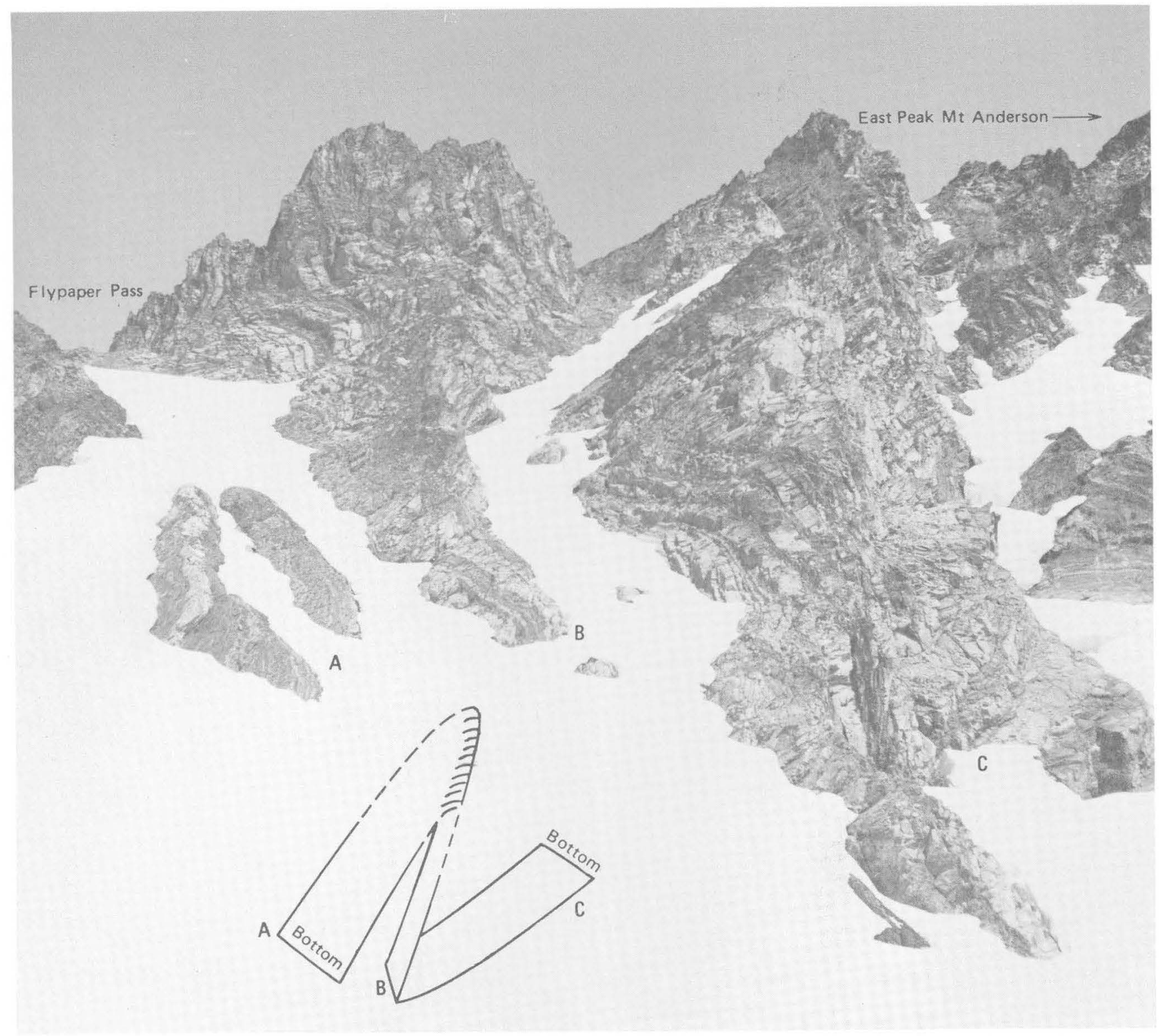

Figure 17.-Large overturned drag fold on Mount Anderson viewed from the south, subdomain 14. Data on the tops of beds show the folding although most of the hinges are sheared off. Sketch shows probable shape of the fold, axis plunges about $45^{\circ} \mathrm{S} .35^{\circ} \mathrm{W}$. 
Elements of the structure are summarized for each subdomain in figure 26 . The near-coplanar orientation of all the structures (note the near parallelism of principal beds, cleavage, and axial planes in most sub-

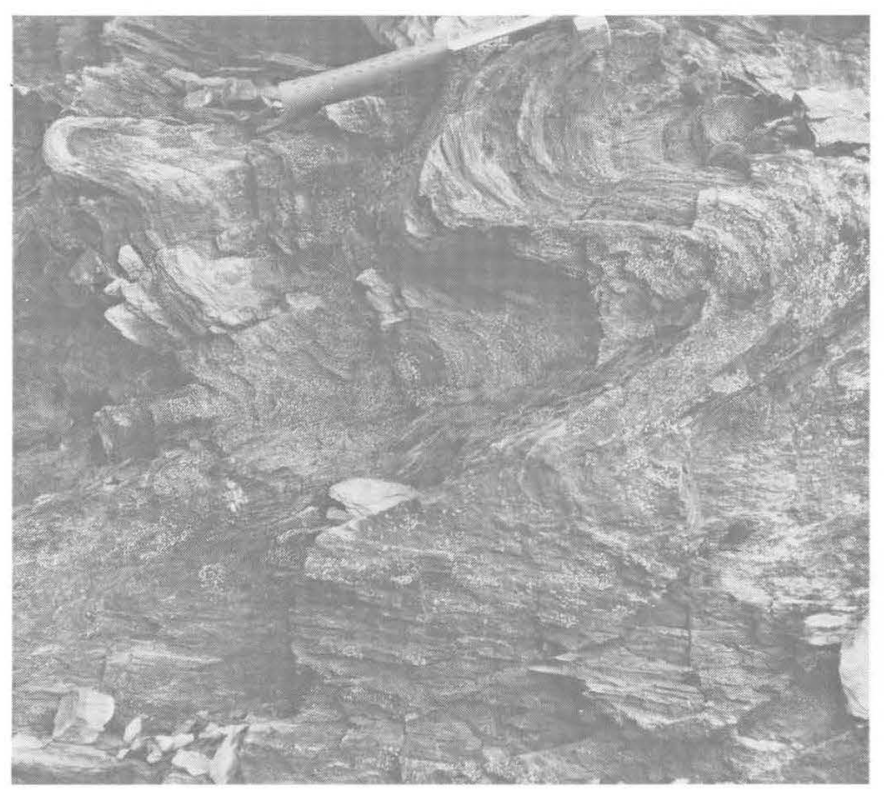

Figure 18.-Folds in cleavage. Traces of (younger) axial-plane cleavage in these folds can be seen to left and below hammer handle. Phyllite in subdomain 10, south ridge of Mount Norton.

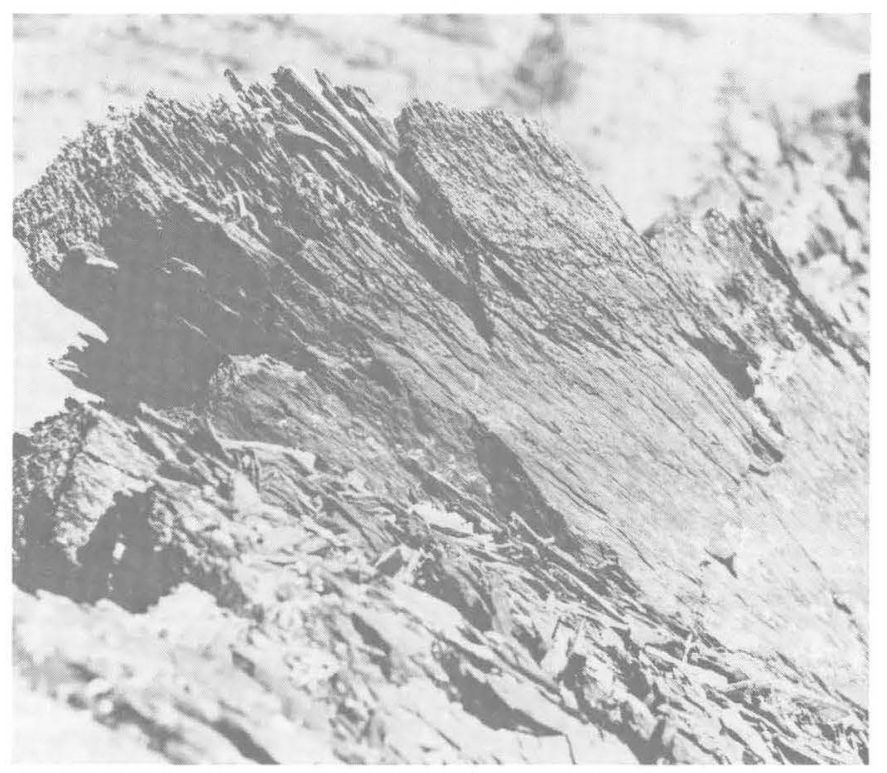

Figure 19.-Pencil structures in red limestone. Pencils parallel to wooden pencil; bedding strikes from left to right and dips steeply away from plane of photograph. Subdomain 7, northeast of Grand Pass. domains) is to be expected in rocks where cleavage dominates.

\section{MULTIPLE FOLDING}

EARLY FOLDING-FORMATION OF THE CORE UNITS

The arcuate structural packets of broken formations that make up the eastern core of the Olympic Mountains probably formed when the depositional sequence (fig. 27A) was folded and faulted (fig. 27B, C). A scheme of this sort, though highly simplified, can be used to explain both the distribution of rocks of various ages in the eastern core units and the overturning of beds away from the core. In figure $27 \mathrm{C}$, the west-facing limbs of the major folds are shown sheared off. The style of folding and sense of yielding in the early stages of the deformation (fig. 27B) are suggested by structures in the western core, where folds are overturned westward (Stewart, 1970, pl. 1; Rau, 1975), and on the northwestern peninsula, where the Crescent Forma-

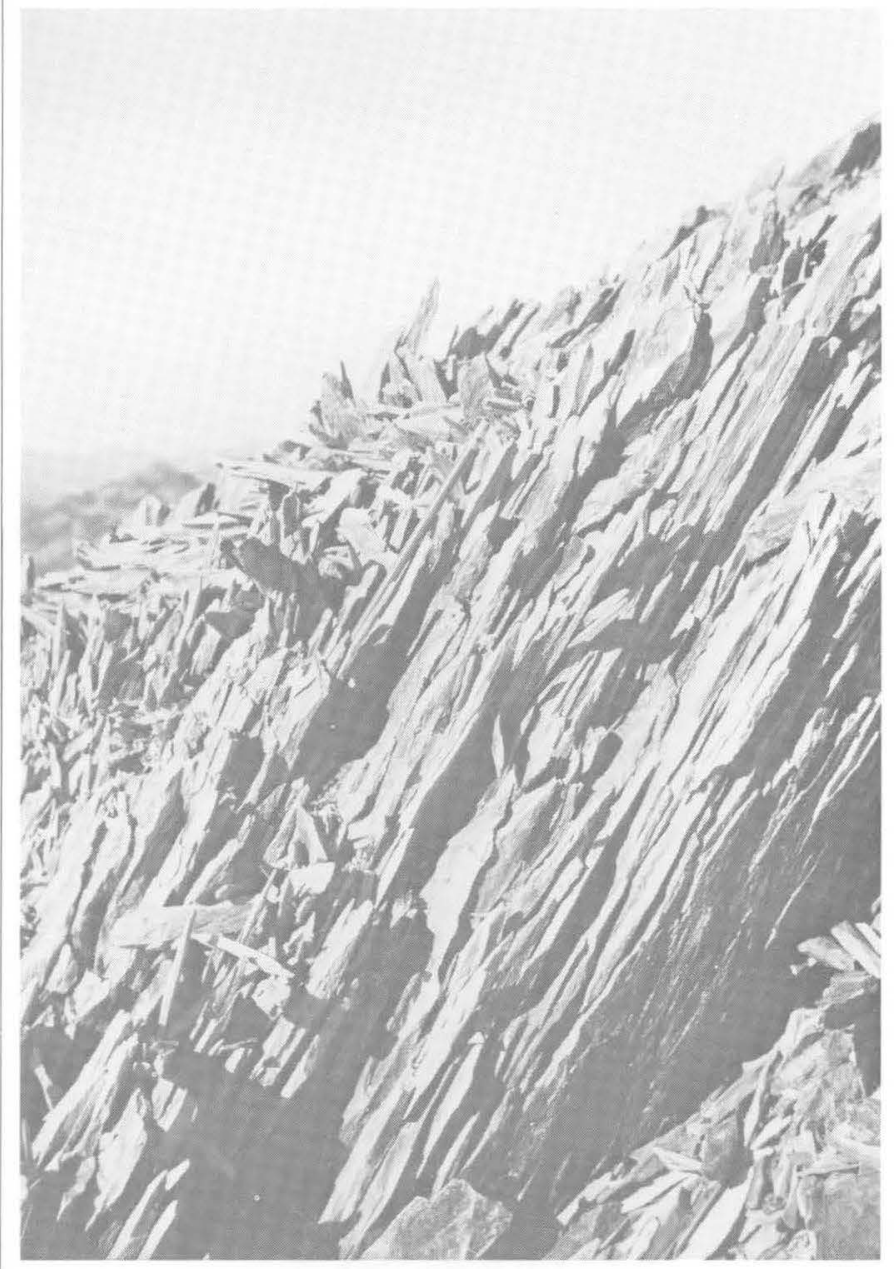

FIGURE 20.-Pencil structures in slate. Subdomain 5, northwest of McCartney Peak. 
tion is thrust over younger rocks (P. D. Snavely, Jr., written commun., 1976; fig. 3). Eastward underthrusting without large-scale folding could also account for

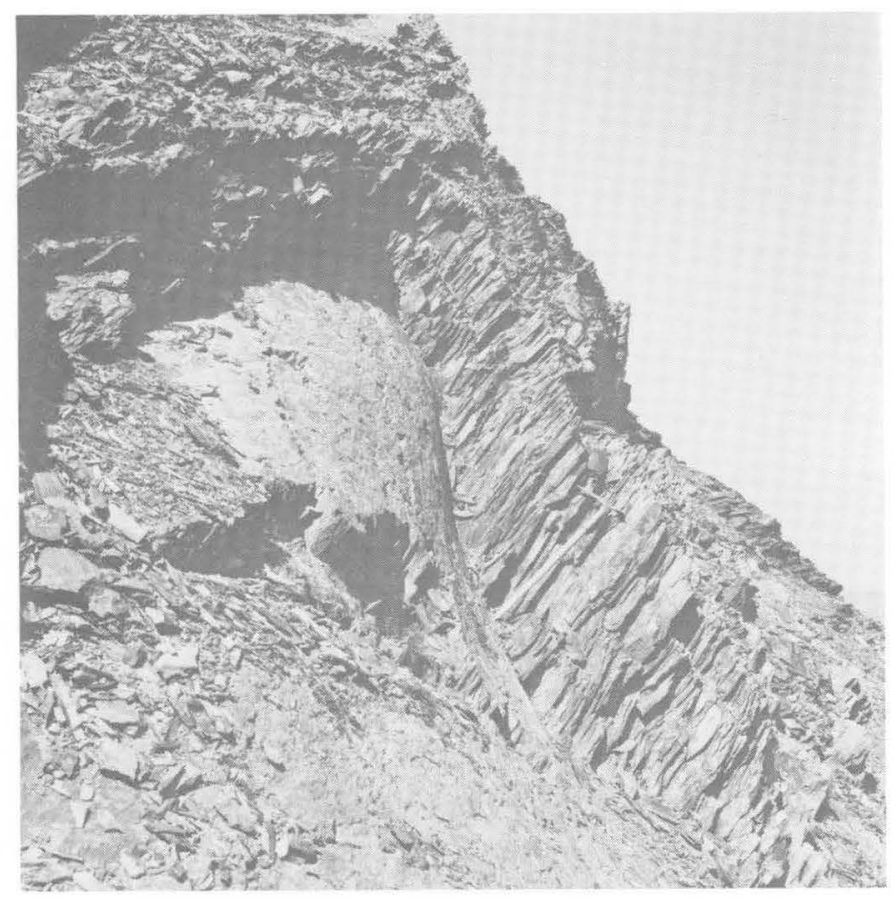

Figure 21.-Large pencils in slate and siltstone at high angle to steep bedding and fold axis. Subdomain 5, ridge north of Mount Cameron.

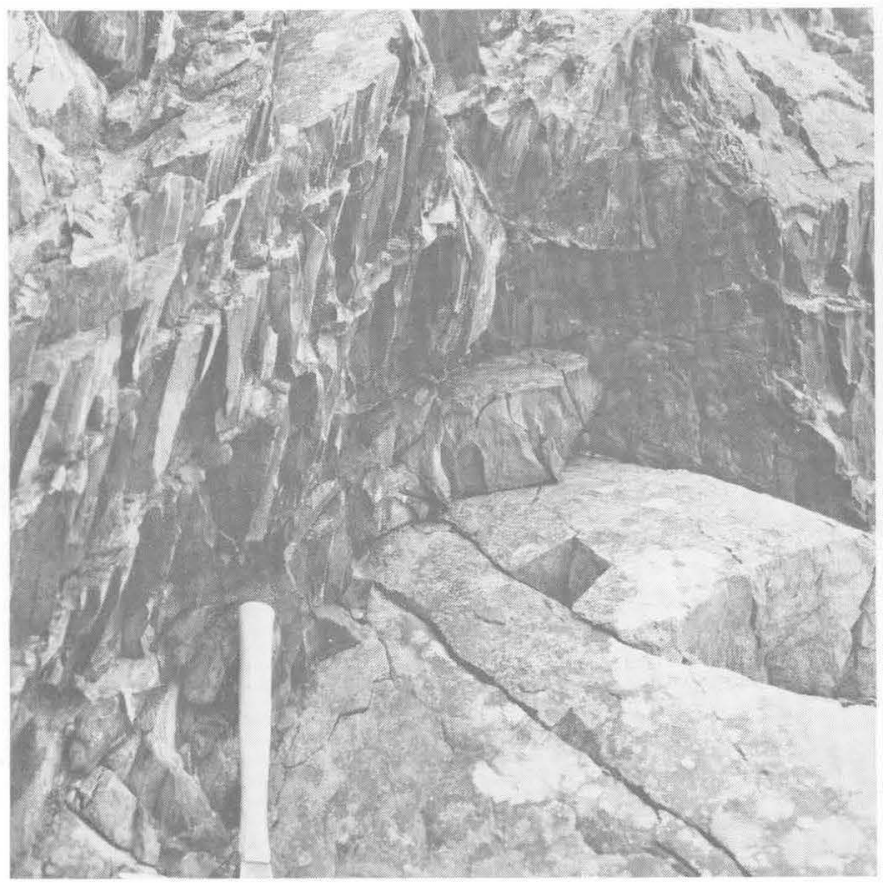

Figure 22.-Crude pencils parallel to axial plane of a fold but roughly perpendicular to bedding and a nearly horizontal fold axis. Subdomain 5, northwest of Grand Pass. the structures in the eastern core. Considerable disruption of bedding probably took place in this early stage of large-scale folding and or thrusting. The formations were broken.

Horizontal fold axes or other B lineations formed at this stage are not evident in the eastern core. As we will show, early fold axes have been rotated by later shear folding. The arcuate bend of the core units did form in this early stage, for the bend controls the orientation of later-formed structures, and the bend indicates that the basaltic horseshoe was forming or already extant. This horseshoe could have formed during this early stage of deformation, or, as an initial reentrant formed by the arcuate distribution of several volcanic seamounts (see Cady, 1975, p. 575), it could have been enhanced as the rocks of the core, predominantly sedimentary, were pressed into and against the more rigid basalt.

The similarity of structural fabric in the peripheral rocks (subdomains $2 \mathrm{~A}$ and $2 \mathrm{~B}$ ) adjacent to the main fault separating core rocks from peripheral rocks is to be expected in this scheme (see discussion of "Major Structural Terranes"). Although the rigid mass of basalts protected the peripheral rocks from being highly deformed, they were acted upon by the same forces.

The entire eastern core has the aspect of a large steeply plunging fold sheared off on the south side. Although there is no independent way of showing that

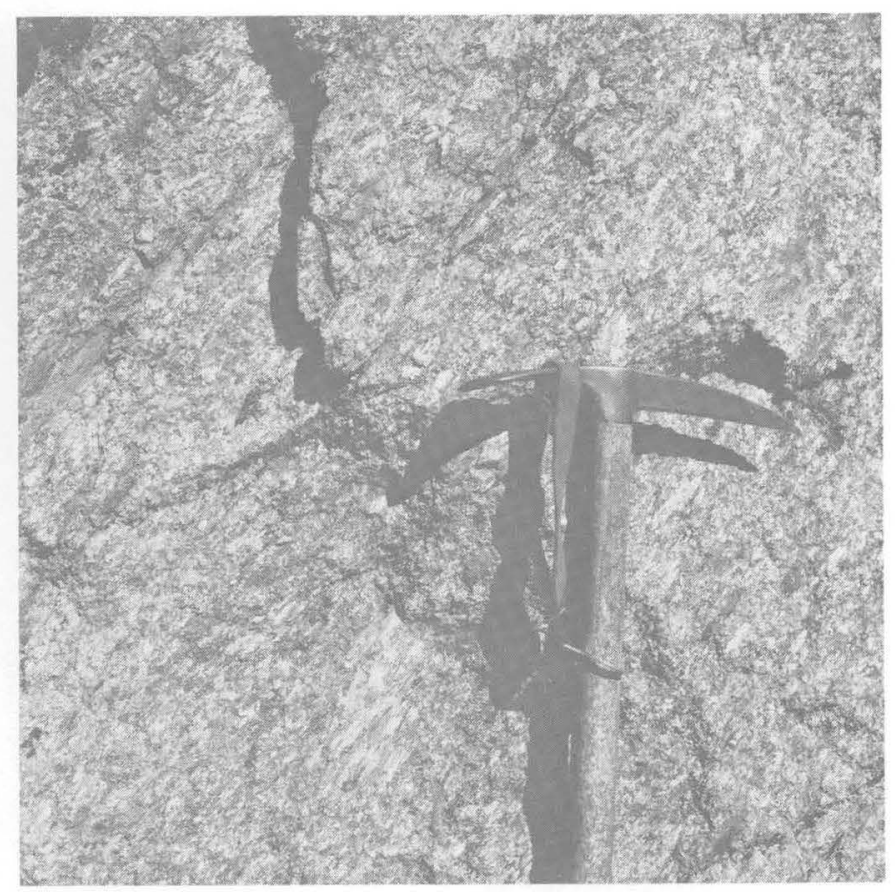

Figure 23.-Lineated granule conglomerate. Subdomain 9, east of Ludden Peak. 


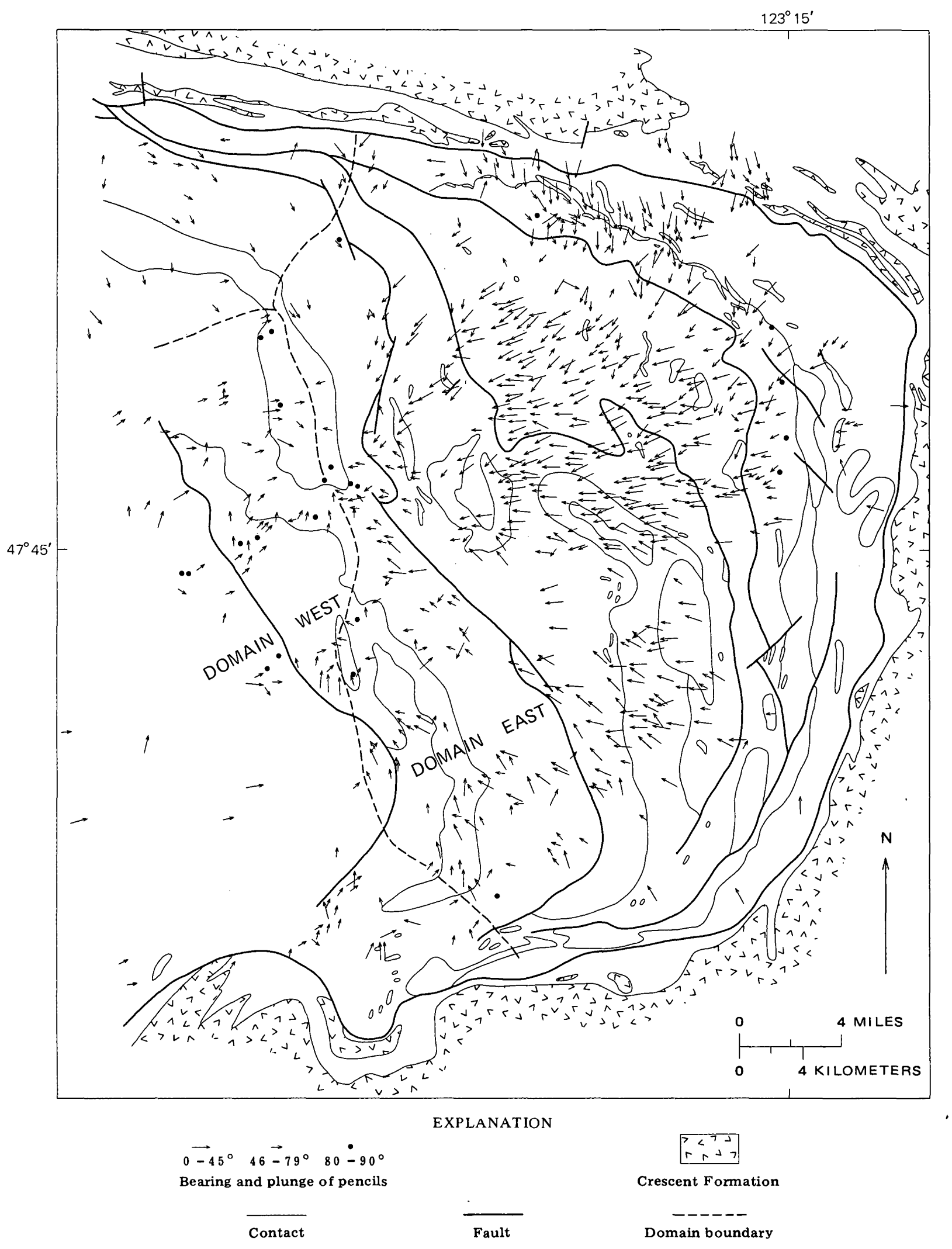

FIGURE 24.-Pencil lineations in the eastern core. 


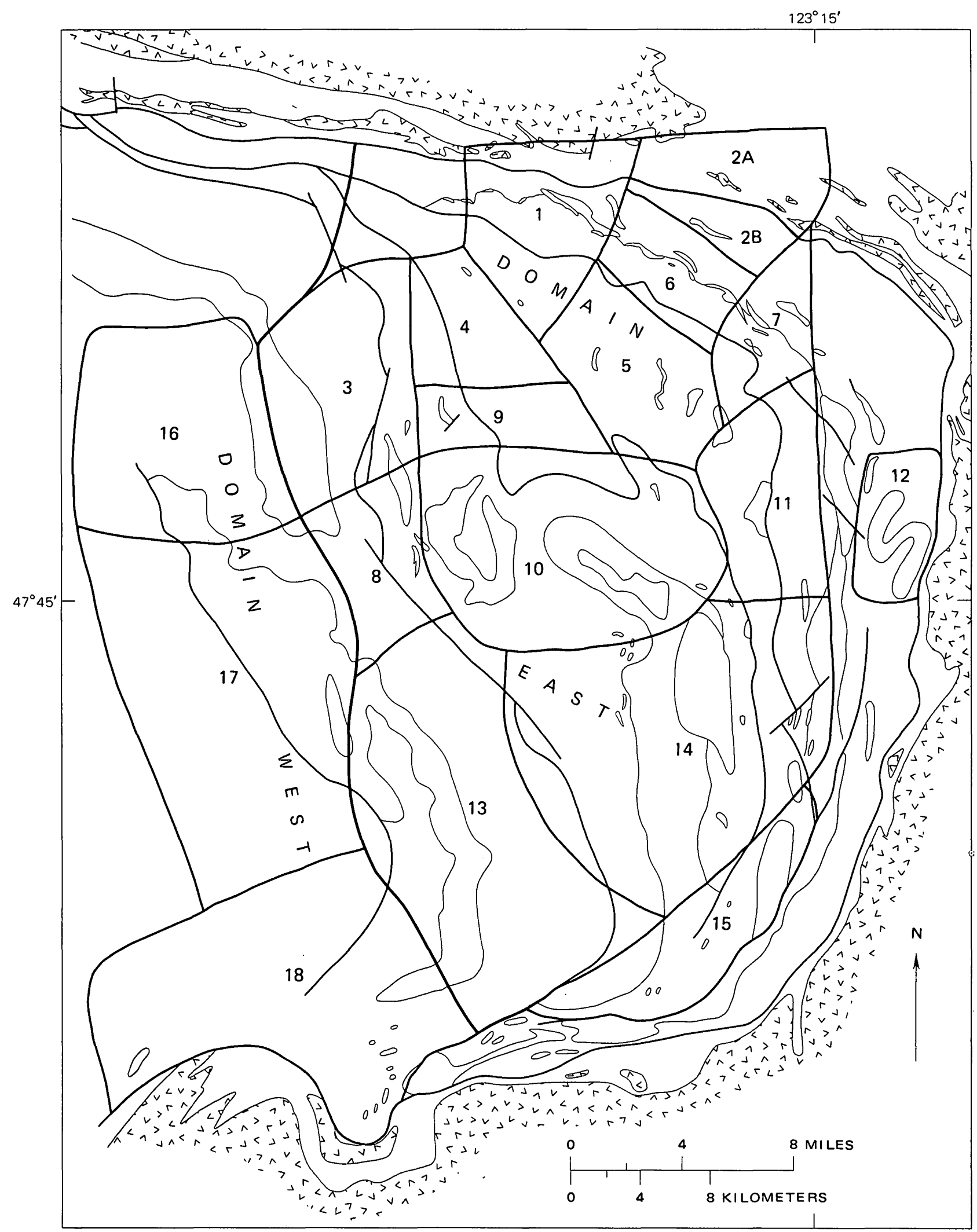

Figure 25.-Domains and subdomains in the eastern core. 
the peripheral rocks have been folded into the horseshoe configuration (see Cady, 1975, p. 578), a pole diagram of bedding attitudes in the basaltic horseshoe crudely defines a $\beta$ fold axis that plunges steeply east- ward (fig. 28). In Domain East, the B elements (fig. 30) do not in any way parallel this "fold." In Domain West, the $B$ lineation and $\beta$ axes of beds and cleavage (fig. 29) generally correspond to this axis, suggesting that at

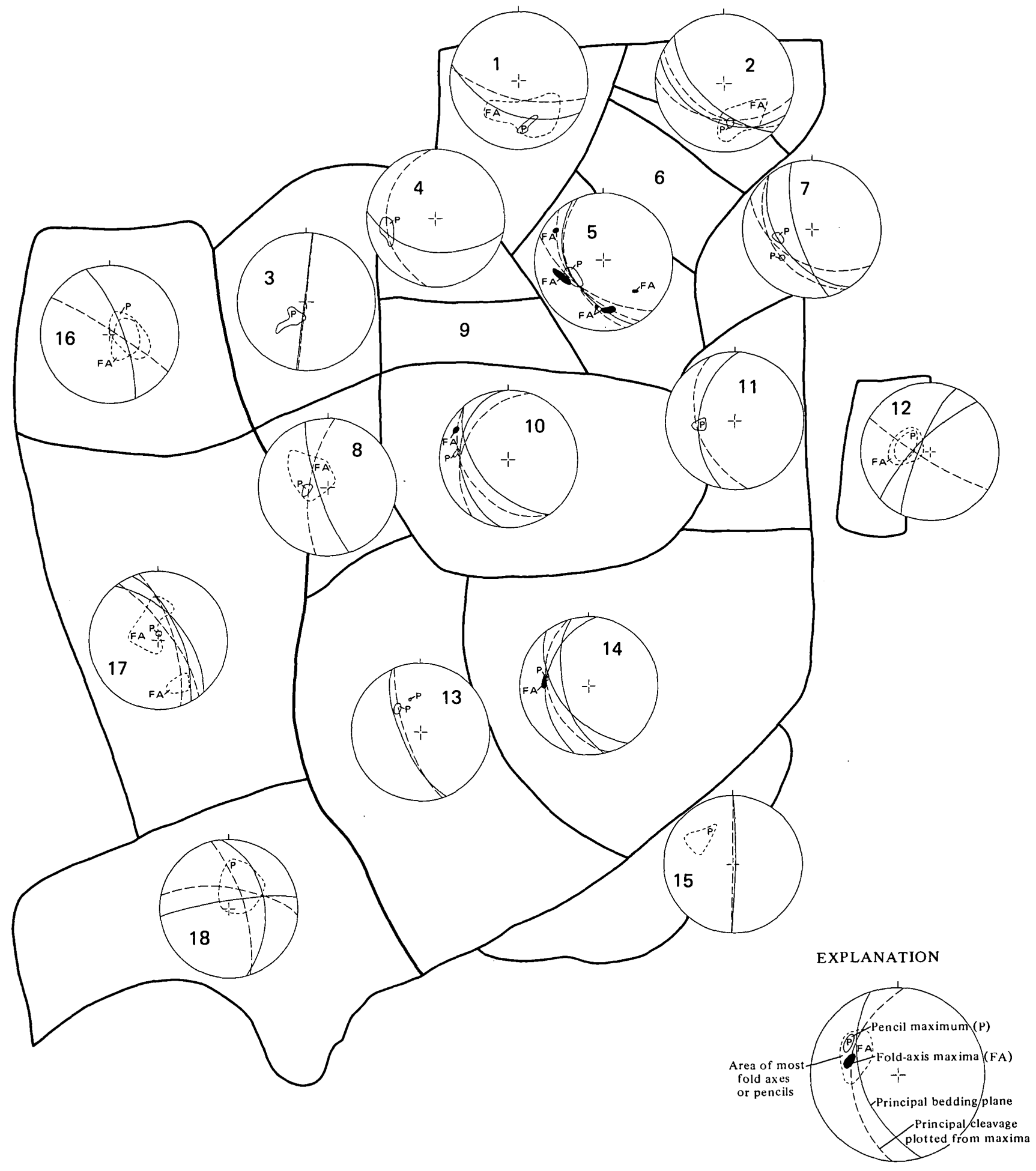

Figure 26. - Summary of principal structural elements for each subdomain. Data from section at end of text "Frequency Diagrams for Subdomains." 
WEST

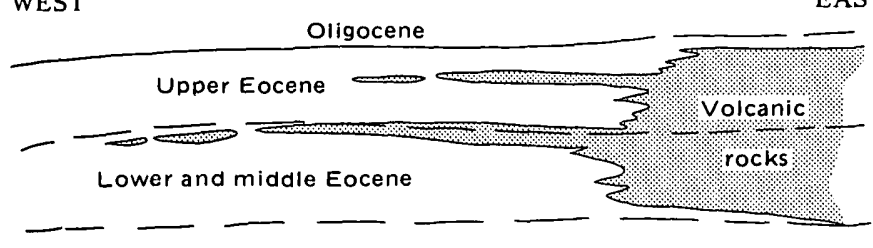

$A$. Depositional sequence prior to folding.

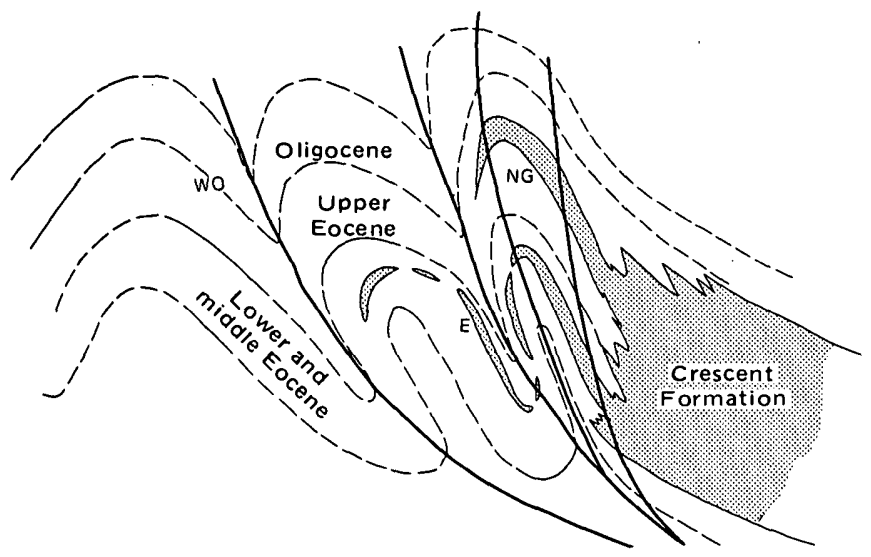

B. Early folding and position of faults. WO, E, and NG denote the western Olymplc, Elwha and Needles - Gray Wolf IIthic assemblages, respectively.

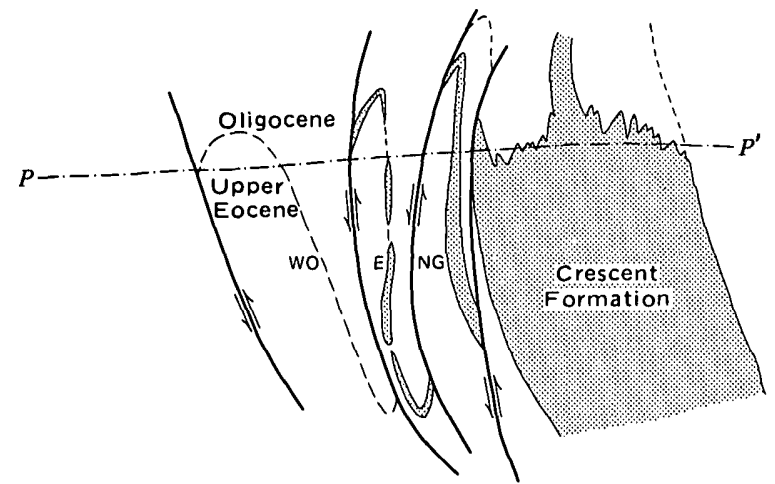

C. After early folding and faulting, major core units established. $P-P^{\prime}$ is form line to show later deformation in $D$.

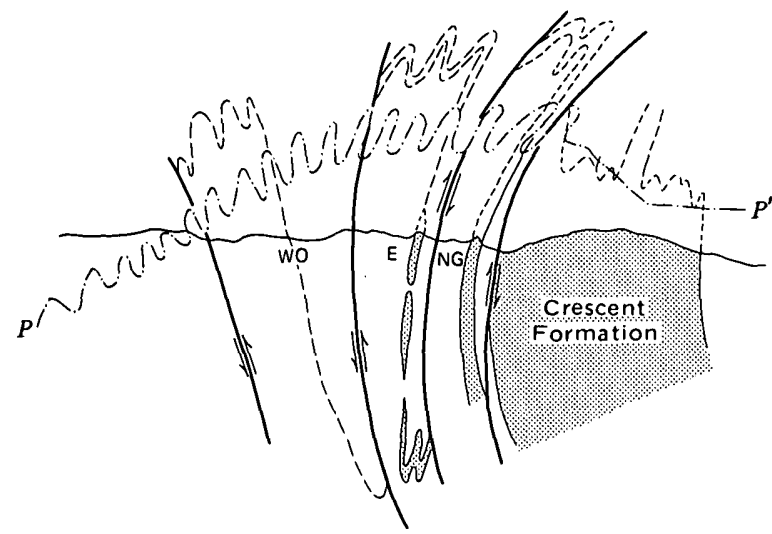

$D$. After shear folding, doming, and erosion occurred. Deformatlon of $P-P^{\prime}$ exaggerated for illustration.

Figure 27.-Development of the eastern core by folding, faulting, and shear folding. Diagram is simplified because deformation and deposition may have gone on at the same time and may have been episodic. some stage in the deformation the basaltic horseshoe either influenced structures in Domain West or developed with them.

The southern fault zone must have developed in this stage, for structures parallel to it are rearranged by later cleavage (see below) and it seems to be a part of the horseshoe fold. Although some of the major rock units are truncated by the fault zone, others curve around sharply to the southwest to parallel the southern arm of the horseshoe. On an outcrop scale, north- to northeast-trending bedding is broken and rotated by shear movement along later northwest-trending cleavage; bedding maxima (fig. 26) reflect the rearranged bedding even though the gross lithologic units curve around to the southwest. Subdomain 18 contains elements of both the fault zone and later northwesttrending cleavage.

\section{LATE FOLDING AND DOMING-FORMATION OF THE PENCILS}

Summary diagrams for Domain East (fig. 30) indicate considerable complexity, but the data reveal major features of the structure not as well shown in the subdomains. In Domain East, there is considerable scatter of orientations, especially of bedding, cleavage, and axial planes, a pattern to be expected in multiple folding. From the field evidence, we have assumed that rocks were deformed predominantly by shear folding,

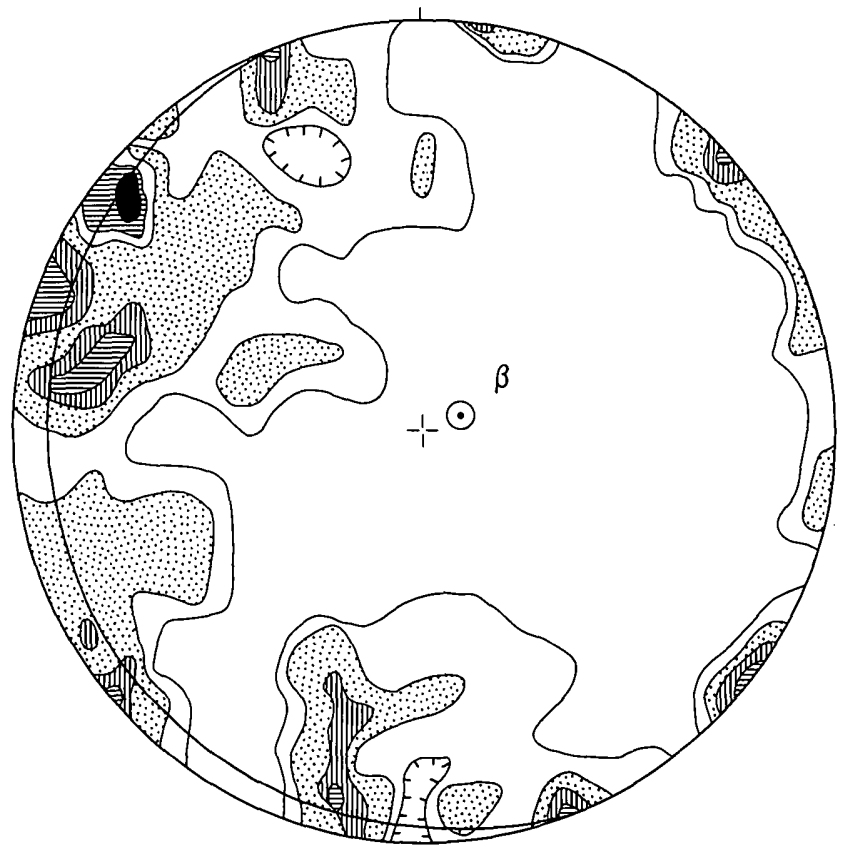

Figure 28.-Ninety-five poles to bedding in volcanic rocks in the Crescent Formation within lower $1-3 \mathrm{~km}$ of main part of basaltic horseshoe. Overturned beds, mostly in northeast part of horseshoe, were left out. Contours at 1, 2.1, 4.2, 5.3, and 7.4 percent per 1 percent area plotted by hand. 
and we have not considered flexural slip in the following analysis. In figure $31 A$ a selected maximum for the summary cleavage s-pole diagram (fig. $30 B$ ) is plotted as a principal cleavage orientation that approximately coincides with the partial girdle in the summary diagram for pencils (fig. $30 C$ ). This principal cleavage orientation is well represented by cleavage s-pole maxima in subdomains $1,2 \mathrm{~B}, 4,5,6,7,9$, and 11 . In southern subdomains 13 and 15 , few cleavages correspond to this orientation.

Cleavage of the principal orientation is probably one of the principal planes bounding the late-formed pencils, hence is itself late formed. It intersects earlier planar structures of diverse orientation (mostly earlier formed cleavage and subparallel bedding which are isoclinally folded as well as partially bent around into the arc of the basaltic horseshoe; see strikes of bedding and cleavage in fig. 26). The summary fold-axis girdle (fig. $30 E$ ) intersects the principle cleavage in projection at $a$ (fig. $31 A$ ). Most fold axes represent bedding-plane folds that probably formed in the earlier stage in the deformation. They have been rotated in a plane that defines the girdle (great circle) of figure $30 \mathrm{E}$. Fold-axis maxima near $a$ may indicate that the late shear folds. are in part isoclinal. Ideally, the late shear folding, if isoclinal, rotates earlier formed fold axes into the $a$ direction. Intersection $a$ represents a west-plunging line (kinematic $a$ ) that parallels the direction of movement during the latest stage in shear folding (Weiss, 1959 , p. 100-103). The latest movement in Domain East, then, was in general east-west direction on shear planes (cleavage) dipping southwest. The $b$ kinematic axis for this late shear folding should lie in the cleavage, $90^{\circ}$ from $a$ (fig. $31 A$ ).

Axes of crinkle folds and folds in cleavage (fig. 30I) tend to lie in the synoptic fold-axis girdle, indicating
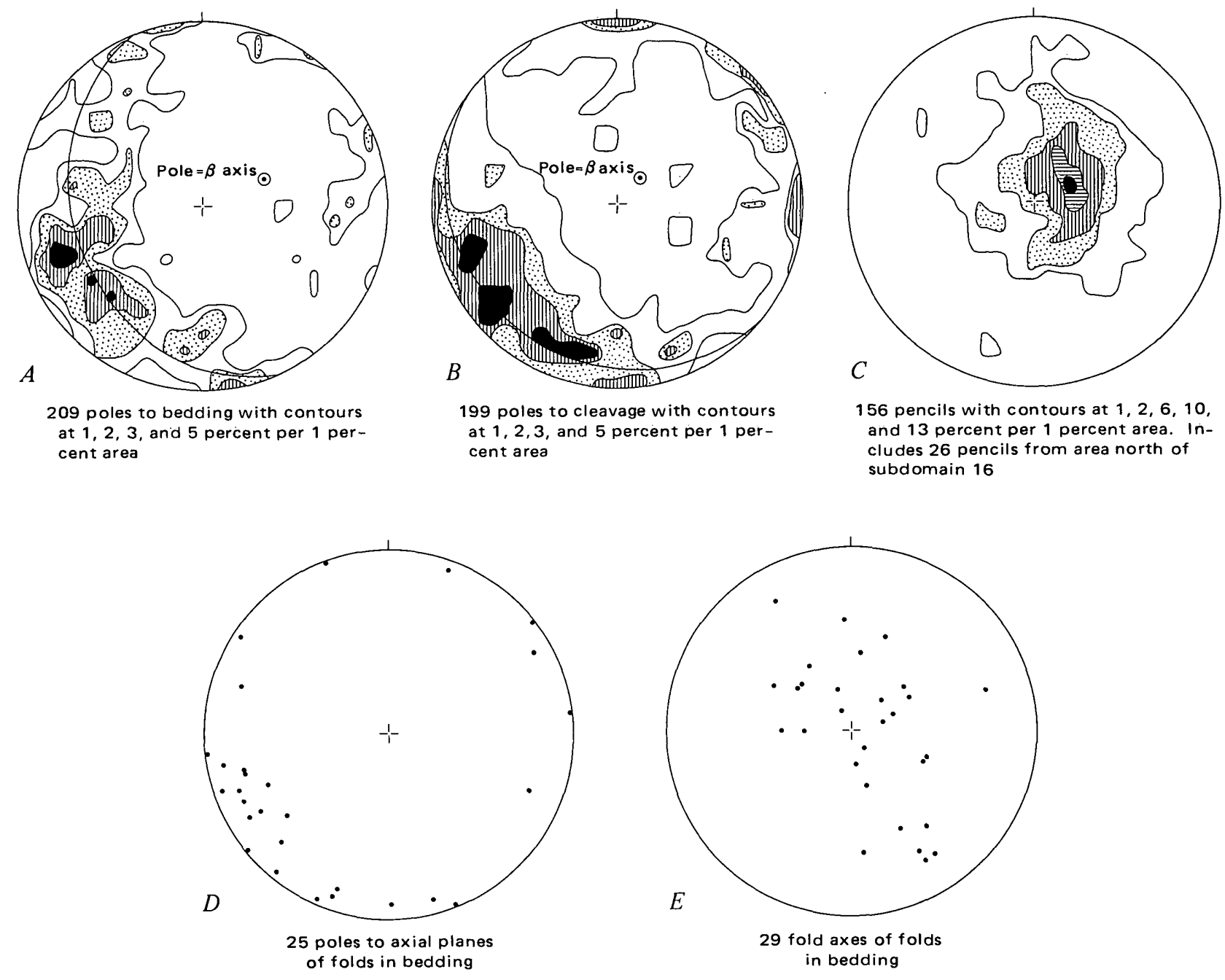

FIgURE 29.-Summary diagrams for structural elements in Domain West. 


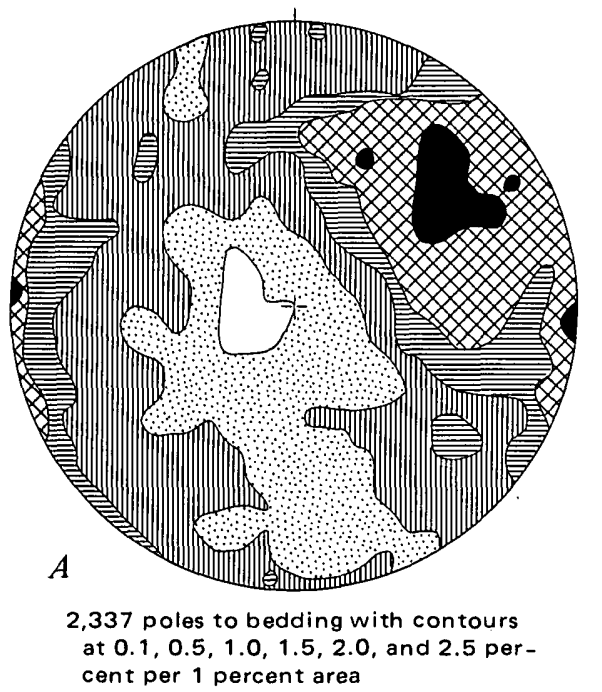

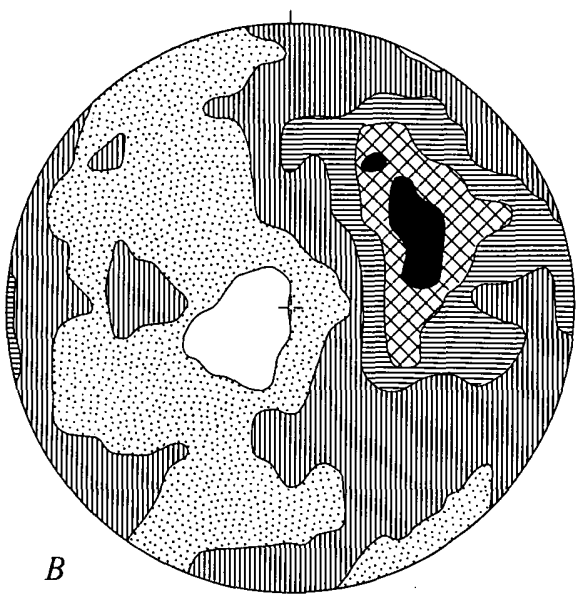

1,716 poles to cleavage with contours at $0.1,0.5,1.5,2.5$, and 3.5 percent per 1 percent area
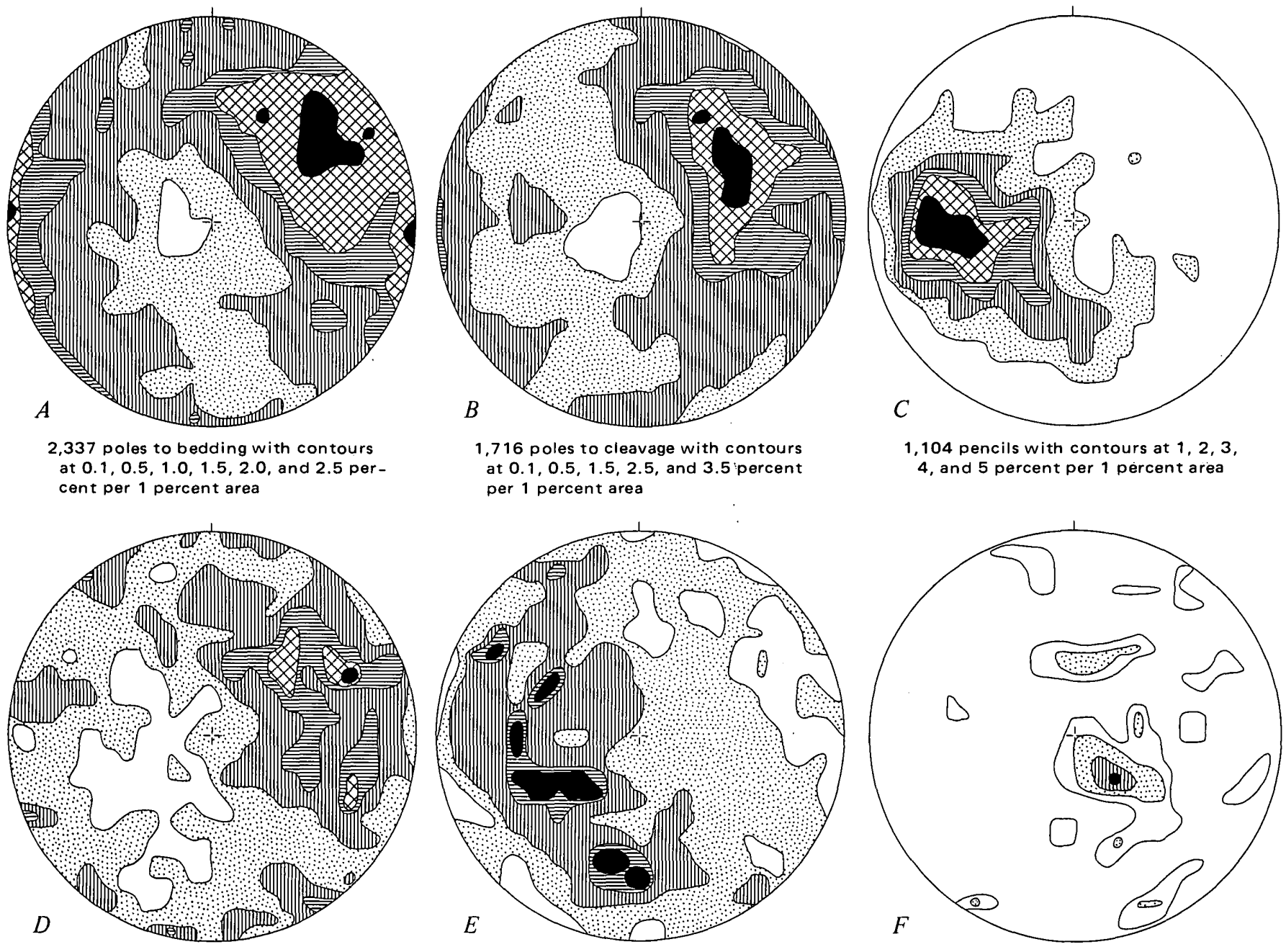

331 poles to axial planes of folds in bedding with contours at $0.3,1,2$, 3 , and 4 percent per 1 percent area
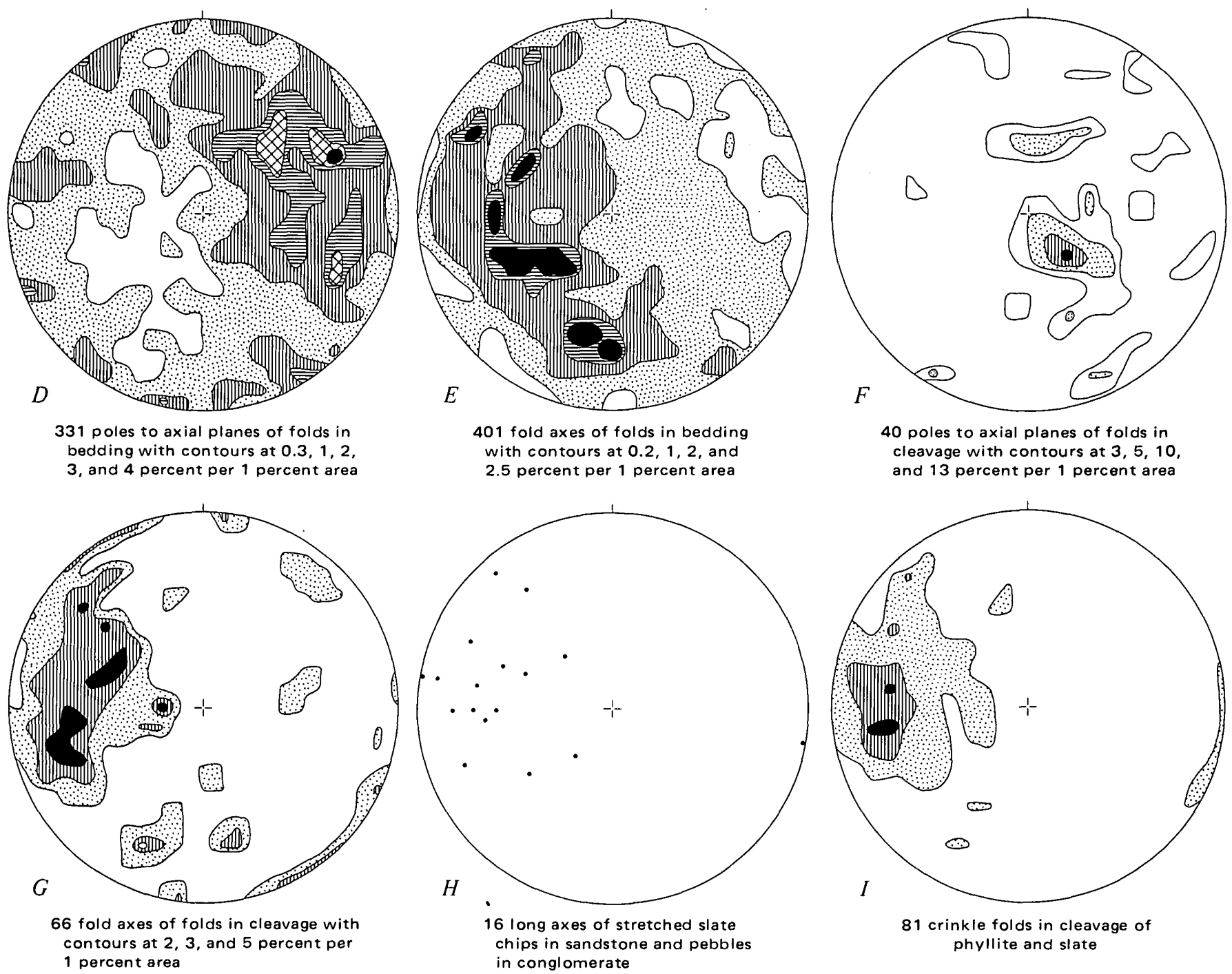

FIgURE 30.-Summary diagrams for structural elements in Domain East. 
that they too are earlier formed B structures. As they themselves formed after cleavage had formed, they indicate multiple shear folding prior to the last stage of shear folding under consideration here. Although stretched-clast lineation (fig. $30 H$ ) usually coincides with the $a$ direction, probably indicating extension in the east-west direction, the small amount of data, especially in subdomains to the northeast, precludes recognition of a possible girdle. If the long axis of the clasts lay in the plane containing the fold axes, some clasts at least would have to parallel earlier formed B elements.

Summary diagrams for Domain West display a fair monoclinic symmetry with a steeply dipping northeast-striking symmetry plane (fig. 29). They are not so amenable to the same analysis as Domain East because they contain much less data and the pencil girdle is less discrete (fig. 29C), making identification of a late cleavage less certain. The summary pencil diagram (fig. $29 C$ ) contains data from the area north of subdomain 16 (figs. 24, and 25), where pencil structure is poorly defined. This area was not otherwise included in the analysis, partly because of sparsity of welldeveloped cleavage, but the pencils help define a partial girdle.

There is considerable continuity in pencil structures across the eastern core, suggesting they all formed by the same process. The fan of cleavage from east to west suggests that the pencils formed together in the latest stage of deformation and that, on the west, steeply eastward-dipping late cleavage and earlier planar structures controlled pencil formation. By analogy to the features discussed for Domain East, then, a weak girdle of early-formed fold axes (fig. 29E) intersects a principal cleavage plane near a possible pencil girdle at $a$ (fig. $31 B$ ). At $90^{\circ}$ from $a$ in the cleavage is the $b$ axis of the late shear folding. It is subhorizontal and trends north northwest; its proximity to the theoretical $b$ axis for Domain East shows the results of the analysis for the two domains to be consistent. In Domain West, the $a$ movement direction is roughly parallel to the monoclinic symmetry plane of the total structural fabric, as is required by the symmetry.

The late shear folding is present in both major domains. The direction of yielding, based on the orientation of $a$, was steeply up and westward in Domain West and more gently up and eastward in Domain East. The analysis of only two major domains has generalized kinematic direction $a$ into two directions, whereas actually it probably is distributed in a fan from west to east, radiating upward from a sub-horizontal northnorthwest-trending $b$ axis. We picture a mushrooming dome, with fan of cleavage, extended asymmetrically to the east (fig. 27D).

\section{SUMMARY OF THE DEFORMATION}

By our analysis, deformation of the rocks of the Olympic Mountains can be summarized as four episodes:

(1) The thick sequence of lower Tertiary sandstone and shales with thin interbeds of pillow basalt (fig.

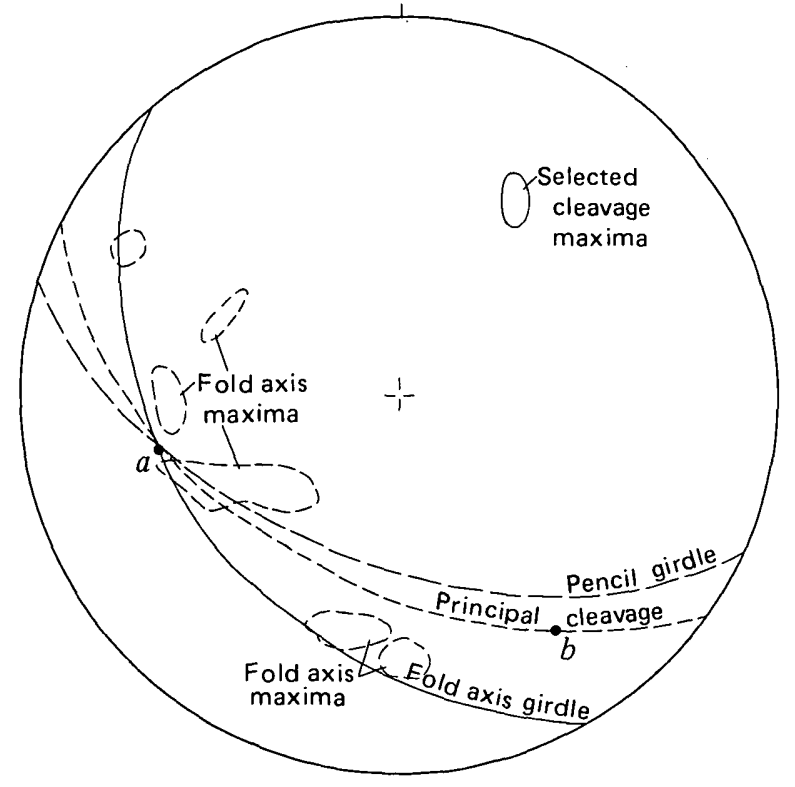

A

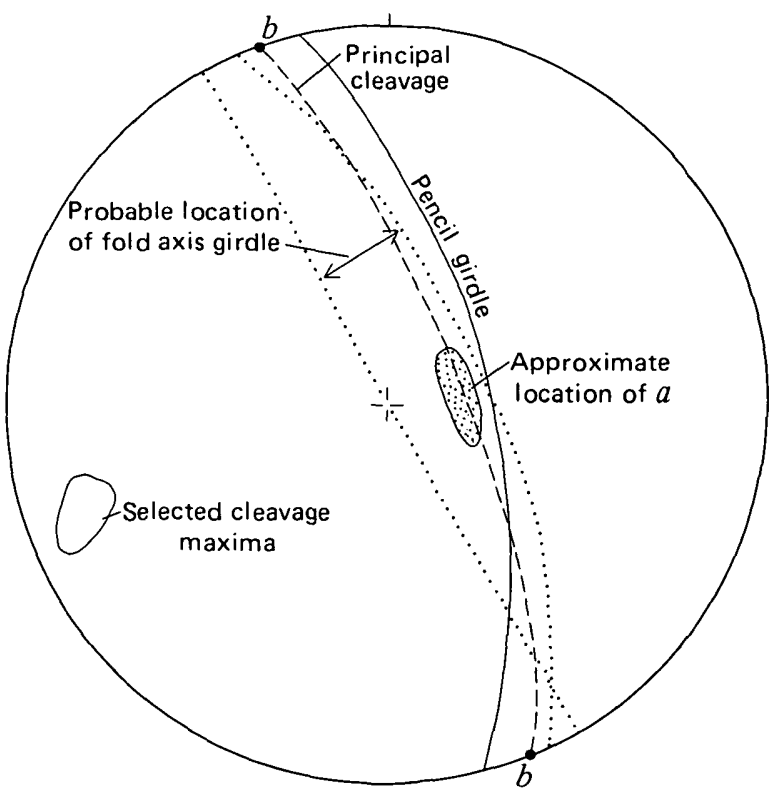

$B$

Figure 31.-Intersection (a) of the principal shear cleavage of the late stage of deformation with girdle of early fold axes and constructed $b$ kinematic axis. $A$, Domain east. $B$, Domain west. 
$27 A$ ) was isoclinally folded along roughly northwestsoutheast trending axes, then faulted, imbricated, and overturned westward (fig. 27B). Imbricate faulting without major folding would also produce the pattern seen today. Rocks may not have been highly lithified during early stages of deformation, but cleavage could have developed very early (Moore and Geigle, 1974, p. 509). The folding and imbrication may well have begun before deposition of Oligocene rocks.

(2) Continued deformation under east-west compression pressed the core rocks into an arc of basaltic rocks that was forming in response to deformation or was already extant from the initial distribution of seamounts. The easternmost core rocks were bent into the horseshoe fold on the north but were mostly sheared off below the basalt on the south and southeast along the southern fault zone.

(3) Deformation continued, and as the pile of sedimentary rocks, now thoroughly lithified, became even more constrained by the basaltic horseshoe, which may have ceased yielding, the core rocks yielded upward and outward by shear folding (fig. 27D). An overall mushroomlike dome, highly asymmetric to the east and northeast, developed with a fan of cleavage. The conspicuous pencil structures formed where the new cleavage intersected older, deformed bedding and cleavage. In much of Domain East, the sense of shear in this last stage of deformation was opposite that of the earlier stages. Any one of the east-dipping shear planes in the eastern core that had undergone eastward underthrusting in the early stages of deformation was now bent over eastward, and movement continued as eastward overthrusting.

There is no way to tell from data in the eastern core if the deformation process was continuous or sporadic, although Tertiary unconformities on the west (Snavely and Pearl, 1975) suggest distinct episodes of deformation.

(4) The final uplift of the Olympic Mountains could well have been isostatic because of the thickened pile of sedimentary rocks. This uplift would increase the overturning of structures on the east, especially if there was considerable differential uplift in the center of the range as suggested by uplift to higher elevations of rocks of the highest metamorphic grade (see Tabor, 1972, p. 1811).

\section{PLATE MARGIN TECTONICS}

The sedimentary history and style of deformation in the western core led Stewart $(1970$, p. 66$)$ to propose plate margin deformation in the Olympic Mountains. The severe disruption of the eastern core rocks and the overall progression of ages from oldest to youngest westward, even though tops indicate eastward young- ing, is strong evidence for subduction (Maxwell, 1974, p. 1195). Recent studies of trench deposits have developed a scenario of deformation that in part at least fits the history of deformation in the Olympic core rocks (see Grow, 1973, fig. 6; Karig and Sharman, 1975, figs. 2, 7; Moore and Karig, 1976, p. 1266-1267). A generalized section (fig. 32) based on a figure from Karig and Sharman (1975, p. 3791) illustrates how Olympic core rocks may have been emplaced in the accretionary prism. The absence of blueschist-facies rocks and ultramafic rocks is evidence that Olympic rocks were accreted high in the subduction zone, not dragged down the descending slab or mixed with mantle material.

There is no exact analogy between Olympic rocks and typical island-arc systems because massive accumulations of submarine basalt similar to the probable seamounts of the Crescent Formation (Snavely and Wagner, 1963, p. 3-5; Lyttle and Clarke, 1975) close to the continental margin (see Cady, 1975, p. 579-580) have not been reported elsewhere. In the alternative model proposed by Glassley $(1974$, p. 792) and Glassley, Lyttle, and Clarke (1976), oceanic basalt of a ridge or intraplate seamount occurring in the lower part of the Crescent Formation is juxtaposed by faulting with Hawaiian Island-type basalt of the upper part of the Crescent Formation. This interpretation implies that at least the lower part of the Crescent Formation was partially subducted in the early stages of deformation. Whatever the origin of the basalt, its great mass provided a resistant bulwark to the subducted sediments. The deformation history of the eastern core, beginning with imbricate underthrusting and ending with mushroom-like shear folding, is appropriate for an accreted mass of sediments pushed against a rigid mass. The less intensely deformed peripheral sedimentary rocks accumulated back (east) of the subducted part of the accretionary prism, protected from severe deformation by the rigid horseshoe of basalt.

This summary of deformation simplifies a very complex process. There may have been considerable overlap of each stage. Deformation of lower and middle

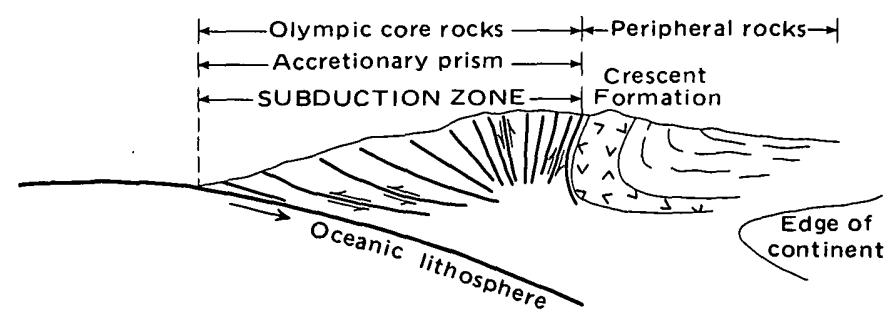

FigURE 32.-Generalized section through Olympic Mountains at plate margin. Modified from Karig and Sharman (1975). 
Eocene rocks of the eastern core may well have begun while upper Eocene and Oligocene rocks were still being deposited to the west. Underthrusting and imbrication in the western core may have continued while late-stage shear folding and doming progressed in the eastern core.

We believe that this study has successfully analyzed the very complex deformation of an exposed subduction zone, mainly owing to the large amount of data and the availability of computers and programs to handle it. Broken formations and melanges elsewhere that appear inordinately complex structurally may yield a coherent deformational scheme through statistical structural analysis.

\section{REFERENCES CITED}

Brown, R. D., Jr., Gower, H. D., and Snavely, P. D., Jr., 1960, Geology of the Port Angeles-Lake Crescent area, Clallam County, Washington: U.S. Geol. Survey Oil and Gas Inv. Map OM-203, scale $1: 62,500$

Cady, W. M., and MacLeod, N. S., 1963, Geological Survey research 1963-Summary of investigations: U.S. Geol. Survey Prof. Paper 475-A, p. A96.

Cady, W. M., Tabor, R. W., MacLeod, N. S., and Sorensen, M. L., 1972, Geology of the Tyler Peak quadrangle, Washington: U.S. Geol. Survey Geol. Quad. Map GQ-970, scale 1:62,500.

Cady, W. M., Sorensen, M. L., and MacLeod, N. S., 1972, Geology of the Brothers quadrangle, Washington: U.S. Geol. Survey Geol. Quad. Map GQ-969, scale 1:62,500.

Cady, W. M., 1975, Tectonic setting of the Tertiary volcanic rocks of the Olympic Peninsula, Washington: U.S. Geol. Survey Jour. Research, v. 3 , no. 5 , p. 573-582.

Cheney, E. S., and Stewart, R. J., 1975, Subducted graywacke in the Olympic Mountains, USA-implications for the origin of Archaean sodic gneisses: Nature, v. 258, p. 60-61.

Cowan, D. S., 1974, Deformation and metamorphism of the Franciscan subduction zone complex northwest of Pacheco Pass, California: Geol. Soc. America Bull., v. 85, p. 1623-1634.

Crook, K. A., 1960, Classification of arenites: Am. Jour. Sci., v. 258, p. $419-428$.

Danner, W. R., 1948, A contribution to the geology of the Olympic Mountains, Washington: Washington Univ., Seattle, M.S. thesis, $67 \mathrm{p}$.

- 1955, Geology of Olympic National Park: Seattle, Olympic National History Assoc., Univ. Washington Press, 68 p.

Glassley, W. E., 1974, Geochemistry and tectonics of the Crescent volcanic rocks, Olympic Peninsula, Washington: Geol. Soc. America Bull., v. 85, p. 785-794.

Glassley, William, Lyttle, N. A., and Clarke, D. B., 1976, New analyses of Eocene basalt from Olympic Peninsula, Washington-Discussion and reply: Geol. Soc. America Bull., v. 87, p. $1200-1204$.

Gower, H. D., 1960, Geologic map of the Pysht quadrangle, Washington: U.S. Geol. Survey Geol. Quad. Map GQ-129, scale 1:62,500.

Grow, J. A., 1973, Crustal and upper mantle structure of the central Aleutian arc: Geol. Soc. America Bull., v. 84, p. 2169-2191.

Harvey, J. L., 1959, Geologic reconnaissance, S. W. Olympic Peninsula: Washington Univ., Seattle, M.S. thesis, 53 p.

Hawkins, J. W., Jr., 1967, Prehnite-pumpellyite facies metamorphism of a graywacke-shale series, Mount Olympus, Washington: Am. Jour. Sci., v. 265, p. 798-818.
Hsü, K. J., 1968, Principles of melanges and their bearing on the Franciscan-Knoxville paradox: Geol. Soc. America Bull., v. 79, p. 1063-1074.

1969, Preliminary report and geologic guide to Franciscan melanges of the Morro Bay-San Simeon area, California: California Div. Mines and Geology Spec. Pub. 35, 46 p.

Karig, D. E., and Sharman, G. F., 3d, 1975, Subduction and accretion in trenches: Geol. Soc. America Bull., v. 86, p. 377-389.

Koch, A. J., 1968, Petrology of the "Hoh Formation" of Tertiary age in the vicinity of the Raft River, western Washington: Washington Univ., Seattle, M.S. thesis, 41 p.

Lindquist, J. W., 1961, Geology and paleontology of the fork area, Dungeness and Greywolf River, Clallam County, Washington: Washington Univ., Seattle, M.S. thesis, 185 p.

Lyttle, N. A., and Clarke, D. B., 1975, New analyses of Eocene basalt from the Olympic Peninsula, Washington: Geol. Soc. America Bull., v. 86 , p. 421-427.

McKee, Bates, 1972, Cascadia-The geologic evolution of the Pacific Northwest: New York, McGraw-Hill Book Co., 394 p.

McMichael, L. B., 1946, Geology of the northeastern Olympic Peninsula, Washington: Washington Univ., Seattle, M.S. thesis, 33 p.

Maxwell, J. C., 1974, Anatomy of an orogen: Geol. Soc. America Bull. v. 85, p. $1195-1204$.

Miller, M. S., 1967, The bedrock geology of the southeast quarter of Mount Steel quadrangle, Washington: Washington Univ., Seattle, M.S. thesis, 78 p.

Moore, J. C., and Geigle, J. E., 1974, Slaty cleavage-incipient occurrences in the deep sea: Science, v. 183, p. 509-510.

Moore, J. C., and Karig, D. E., 1976, Sedimentology, structural geology, and tectonics of the Shikoku subduction zone, southwestern Japan: Geol. Soc. America Bull., v. 87, p. 1259-1268.

Muecke, G. K., and Charlesworth, H. A. K., 1966, Jointing in folded cardium sandstones along the Bow River, Alberta: Canadian Jour. Earth Sci., v. 3, p. 579-596.

Page, B. M., 1966, Geology of the Coast Ranges of California, in Bailey, E. H., ed., Geology of northern California: California Div. Mines and Geol. Bull. 190, 508 p.

Park, C. F., Jr., 1950, Structure in the volcanic rocks of the Olympic Peninsula, Washington: Geol. Soc. America Bull., v. 61, no. 12, pt. 2 , p. 1529

Rau, W. W., 1964, Foraminifera from the northern Olympic Peninsula Washington: U.S. Geol. Survey Prof. Paper 374-G, 33 p.

-1973, Geology of the Washington coast between Point Grenville and the Hoh River: Washington Dept. Natural Resources Bull. $66,58 \mathrm{p}$.

1975, Geologic map of the Destruction Island and Taholah quadrangles, Washington: Washington Geologic and Earth Resources Div. Map GM 13, scale 1:62,500.

Snavely, P. D., Jr., and Wagner, H. C., 1963, Tertiary geologic history of western Oregon and Washington: Washington Div. Mines and Geology Rept. Inv. 22, 25 p.

Snavely, P. D., Jr., and Pearl, J. E., 1975, Geological Survey research 1975-Summary of investigations: U.S. Geol. Survey Prof. Paper 975, p. 128.

Stewart, R. J., 1970, Petrology, metamorphism; and structural relations of graywackes in the western Olympic Peninsula, Washington: Stanford Univ., Stanford, Ph.D. Thesis, 129 p.

1971 , Structural framework of the western Olympic Peninsula, Washington: Geol. Soc. America Abs. with Programs, v. 3, no. 2 , p. 229.

Suppe, John, 1973, Geology of the Leech Lake Mountain-Ball Mountain region, California: California Univ. Pubs. Geol. Sci., v. 107,82 p.

Tabor, R. W., 1971, Origin of ridge-top depressions by large-scale creep in the Olympic Mountains, Washington: Geol. Soc. 
America Bull., v. 82, p. 1811-1822.

1972, Age of the Olympic metamorphism, Washington-K-Ar dating of low-grade metamorphic rocks: Geol. Soc. America Bull., v. 83 , p. $1805-1816$.

1975, Geologic guide to Olympic National Park: Seattle, Univ. Washington Press, $144 \mathrm{p}$.

Tabor, R. W., Cady, W. M., and Yeats, R. S., 1970, Broken formations and thrust faulting in the northeastern Olympic Mountains, Washington: Geol. Soc. America Abs. with Programs, v. 2, no. 2, p. 152.

Tabor, R. W., Yeats, R. S., and Sorensen, M. L., 1972, Geologic map of the Mount Angeles quadrangle, Washington: U.S. Geol. Survey
Geol. Quad. Map GQ-958, scale 1:62,500.

Tabor, R. W., and Cady, W. M., 1978, Geologic map of the Olympic Peninsula: U.S. Geol. Survey Map I-994, scale 1:125,000.

Weaver, C. E., 1937, Tertiary stratigraphy of western Washington and northeastern Oregon: Washington Univ. Pub. in Geology, v. 4, $266 \mathrm{p}$.

Weiss, L. E., 1959, Geometry of superposed folding: Geol. Soc. America Bull., v. 70, p. 91-106.

Weissenborn, A. E., and Snavely, P. D., Jr., 1968, Summary report on the geology and mineral resources of the Flattery Rocks, Quillayute Needles, and Copalis National Wildlife Refuges: U.S. Geol. Survey Bull. 1260-F, 16 p. 


\section{SUPPLEMENTAL INFORMATION}

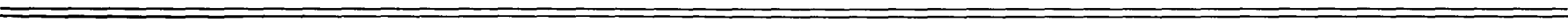


SUPPLEMENTAL INFORMATION

\section{FREQUENCY DIAGRAMS FOR SUBDOMAINS}

Frequency diagrams for subdomains shown on figures 25 and 26 . Contours drawn by hand on percentages calculated and plotted by computer to nearest whole number; contours shown to lower right of each diagram. All percentages calculated per one percent area. Data not contoured if less than 40 points. 


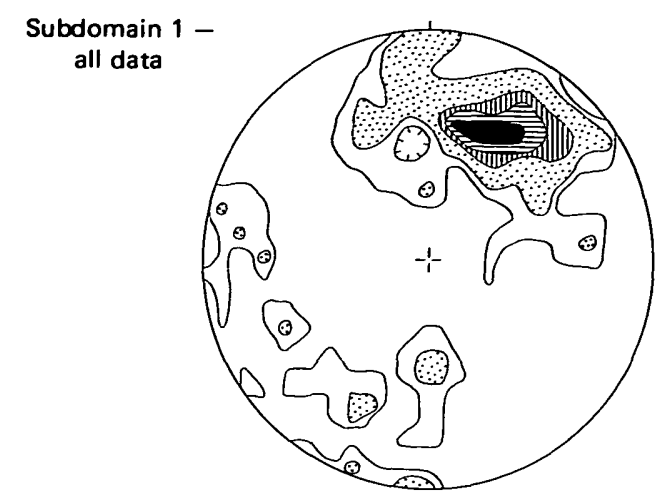

235 poles to beds:

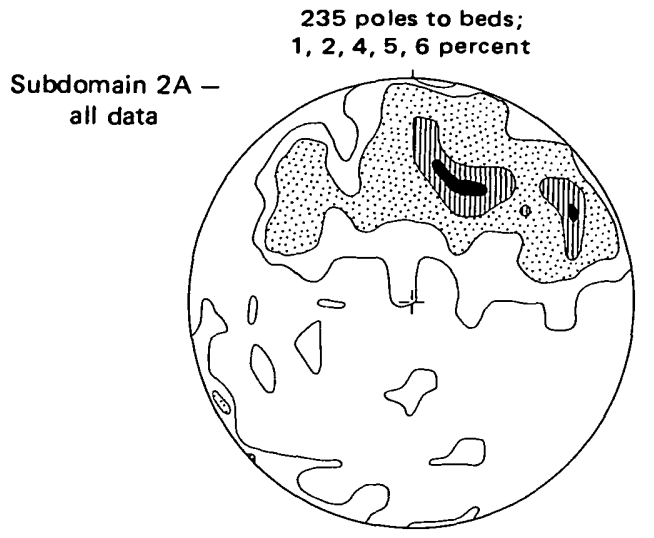

196 poles to beds;

Subdomain 28 all data

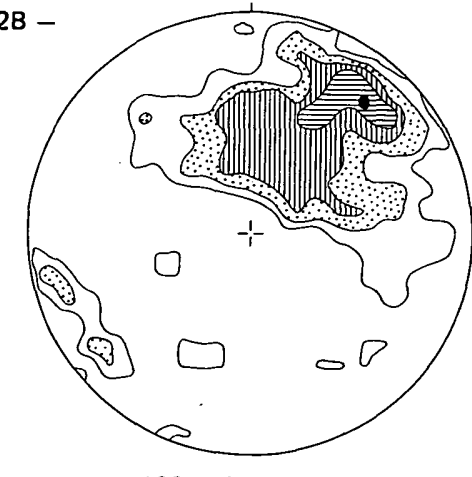

109 poles to beds; 1, 2, 4, 6 percent

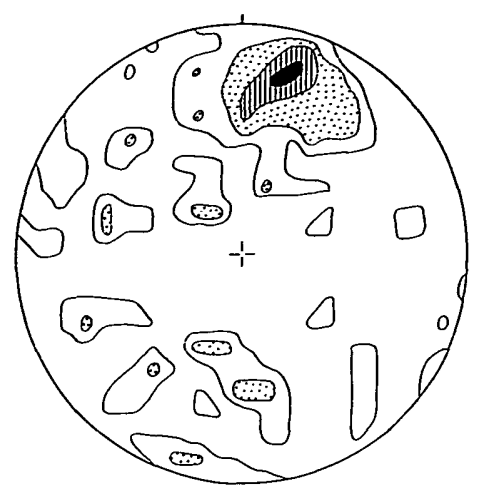

77 poles to cleavage

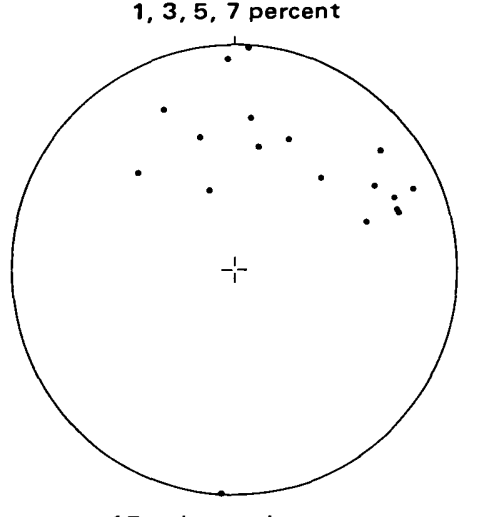

17 poles to cleavage

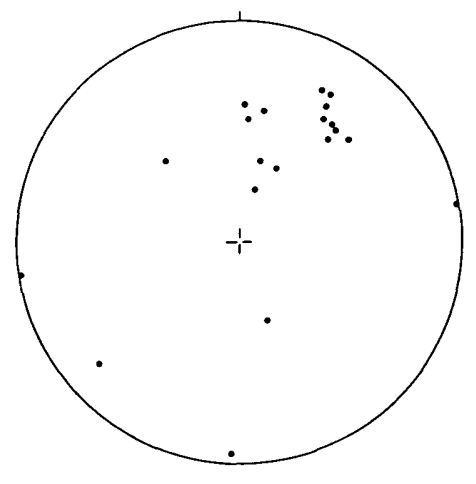

19 poles to cleavage

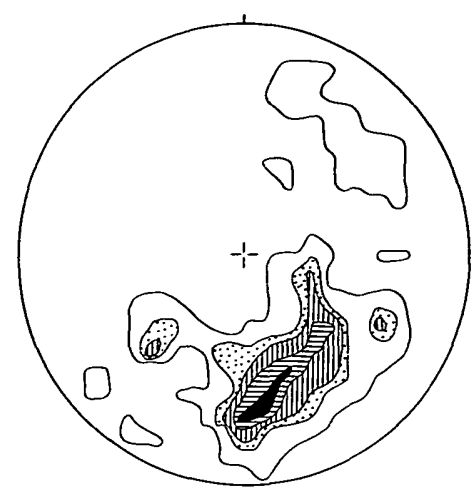

86 pencils; $1,3,5,7,12$ percent
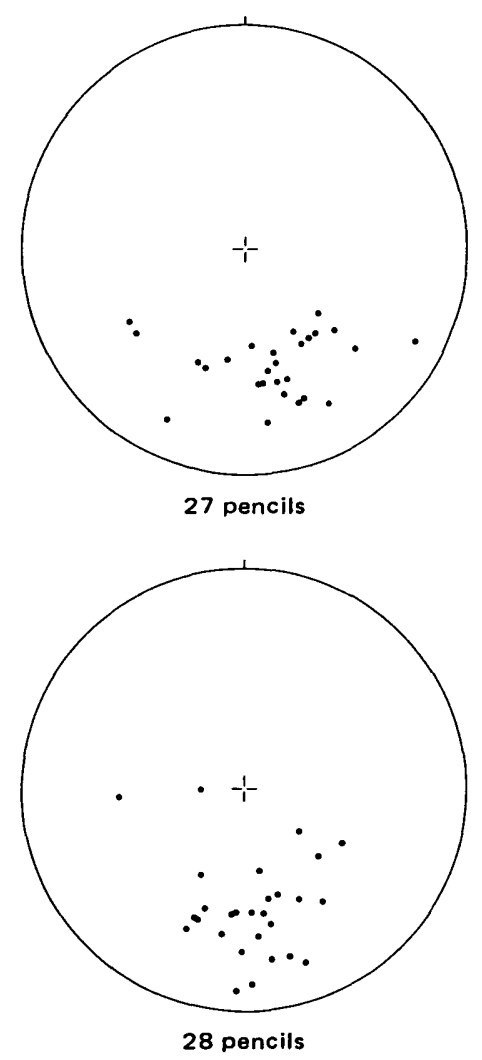

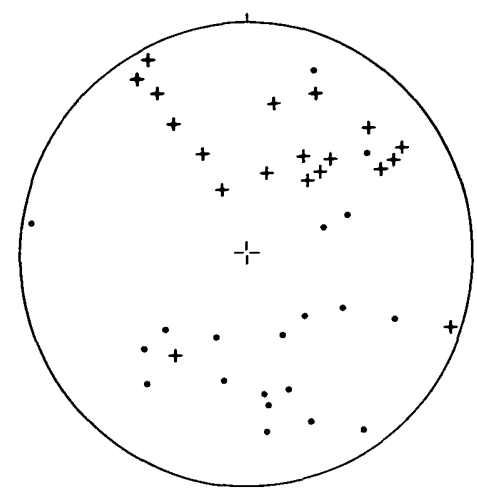

20 fold axes (0); 19 poles

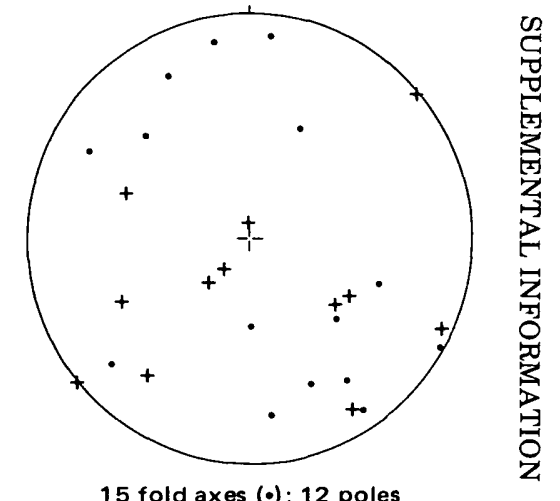

fold axes $(0) ; 12$ pol

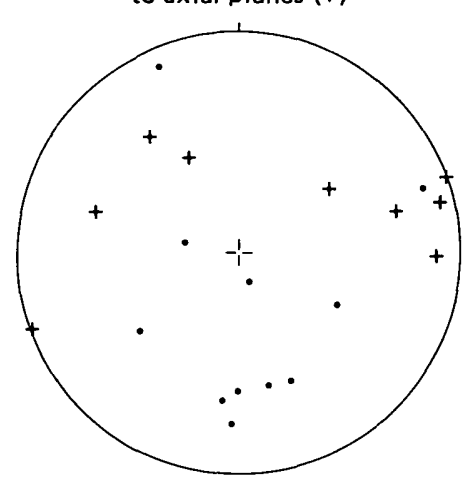

11 fold axes $(\cdot) ; 8$ poles to axial planes $(+)$ 

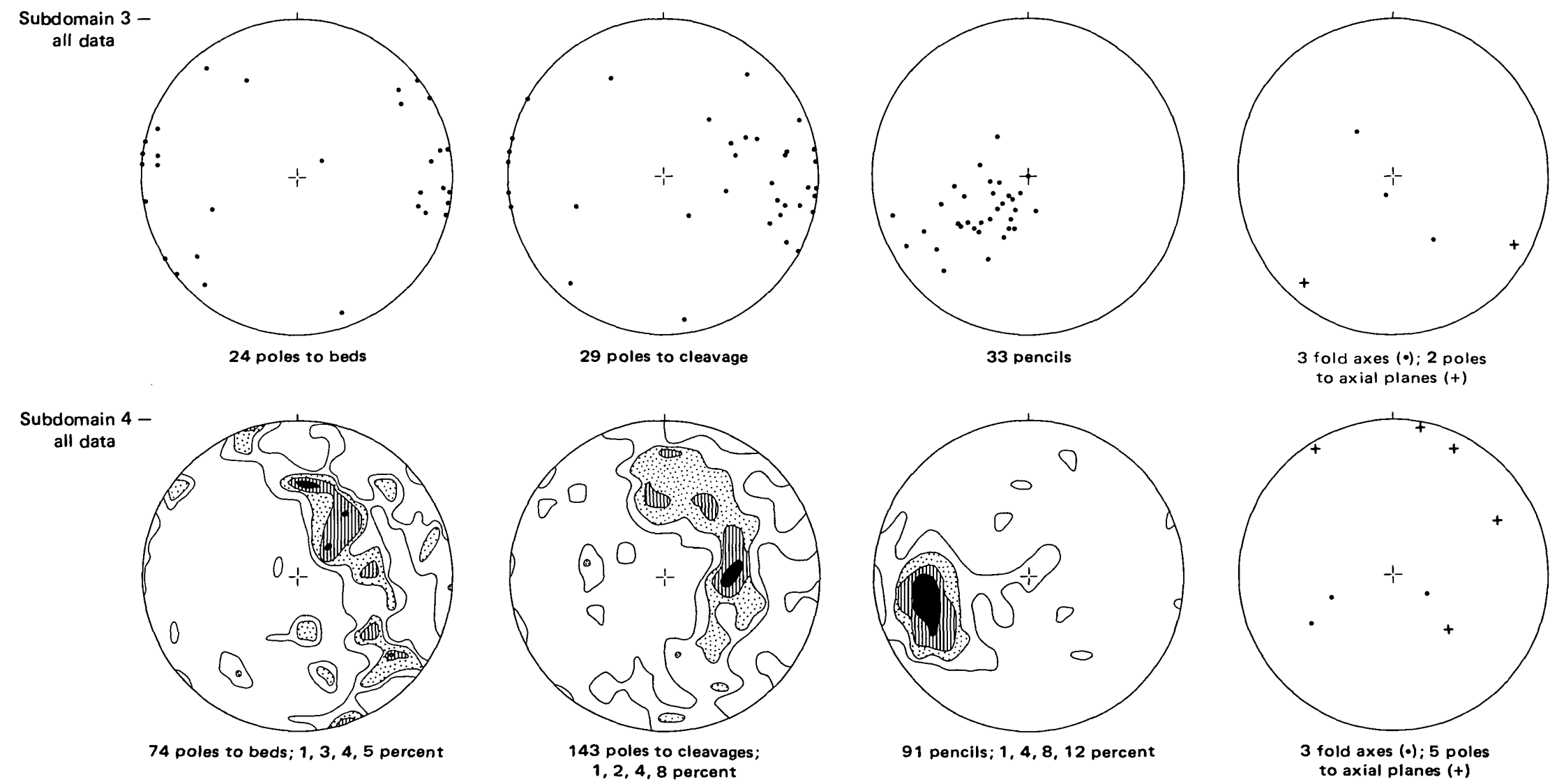

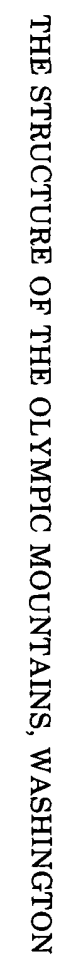

74 poles to beds; $1,3,4,5$ percent

$1,2,4,8$ percent

91 pencils; 1 , 4, 8, 12 percent to axial planes $(+)$ 

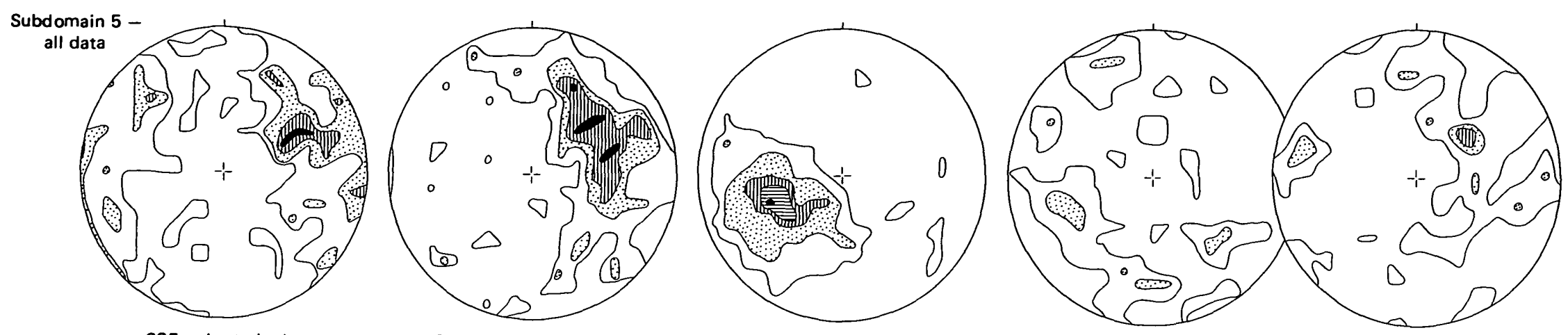

235 poles to beds;

211 poles to cleavages:

146 pencils:

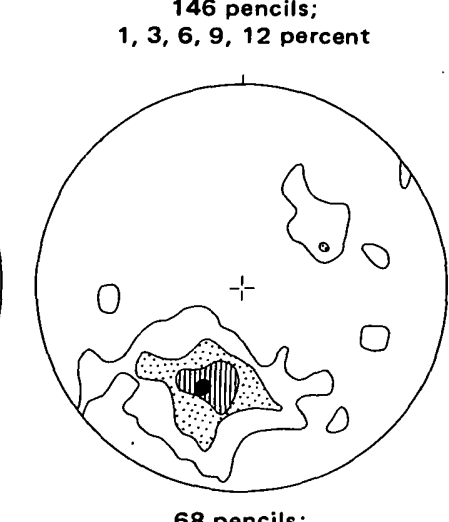

65 fold axes; 2,5 percent

66 poles to axial planes; Subdomain 6 all data
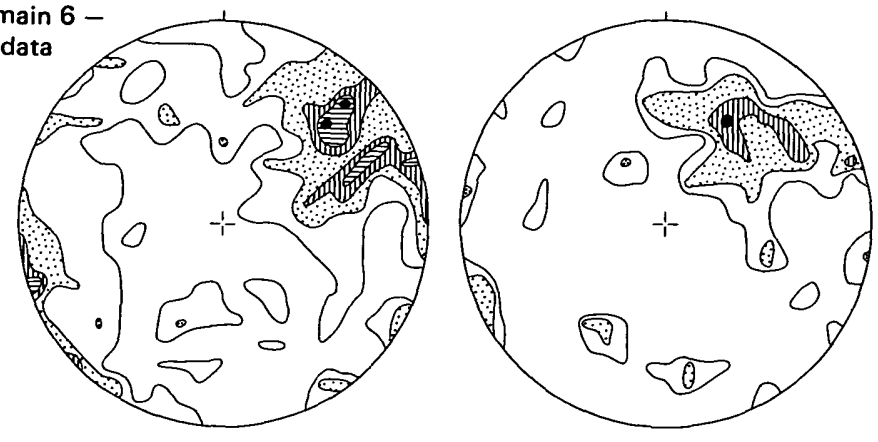

164 poles to beds
$1,2,3,4$ percent

66 poles to cleavage
$2,3,6,9$ percent

68 pencils:

1, 4, 10, 18 percent

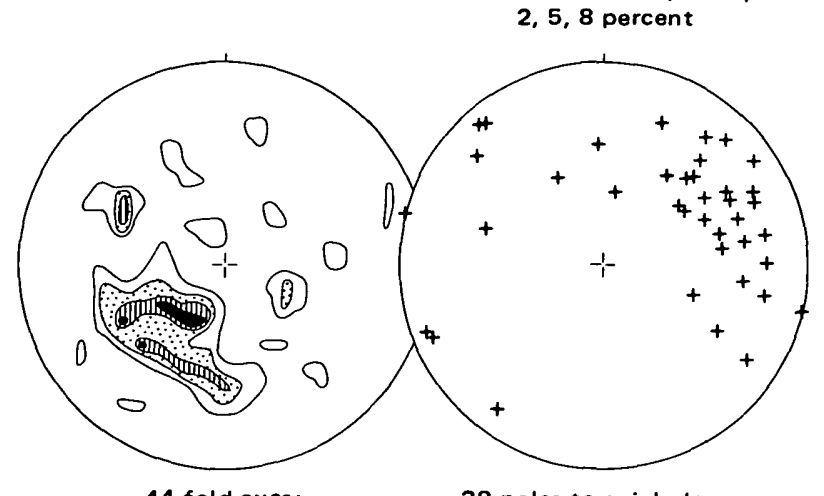

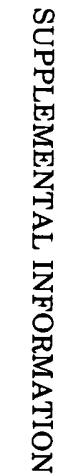

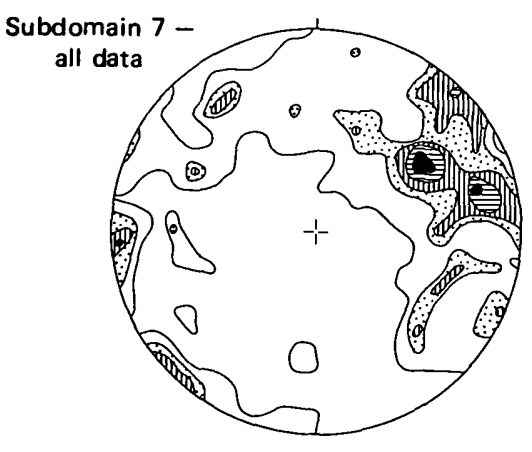

153 poles to beds:

$1,2,3,4,5$ percent

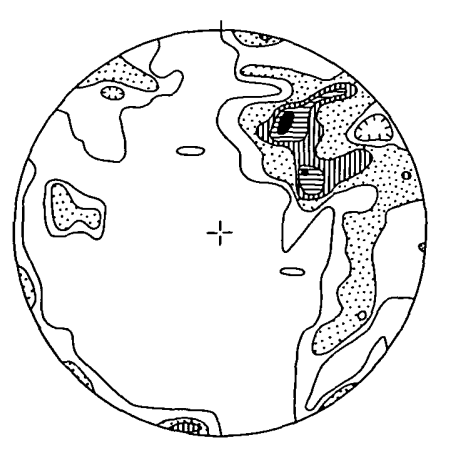

108 poles to cleavages:
$1,2,4,6,8$ percent

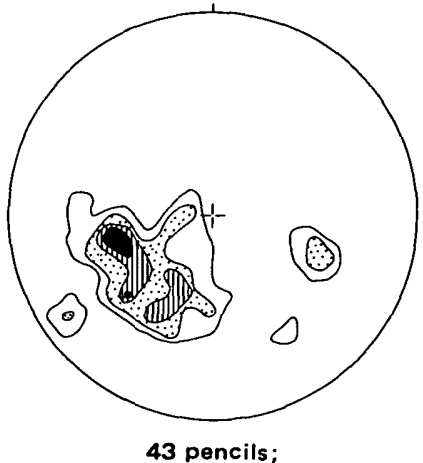

2, 5, 9, 14 percent

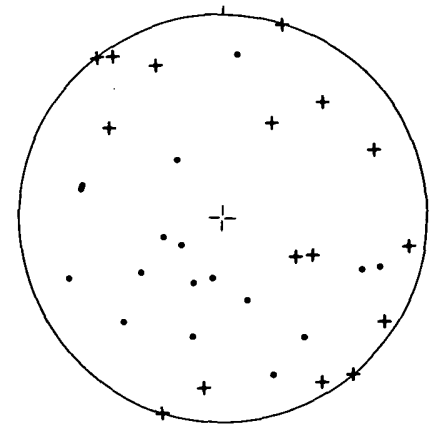

17 fold axes (0): 14 poles 
Subdomain 8 all data

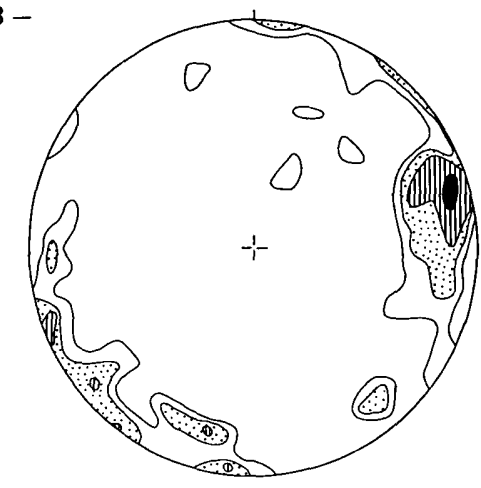

45 poles to beds:

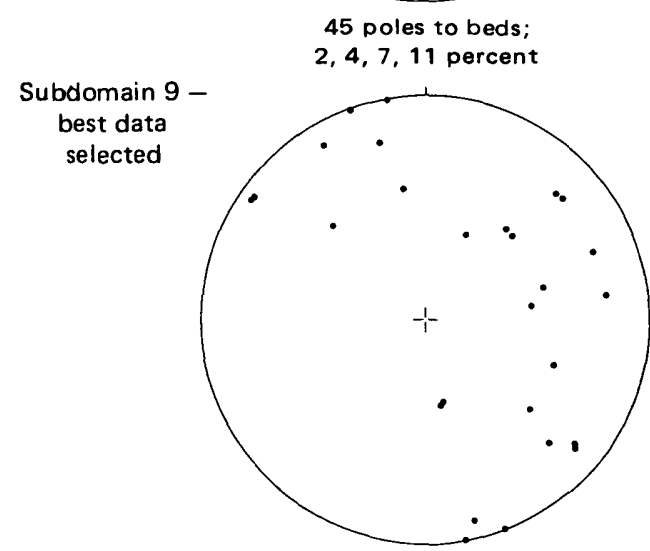

25 poles to beds

Subdomain 10 best data
selected

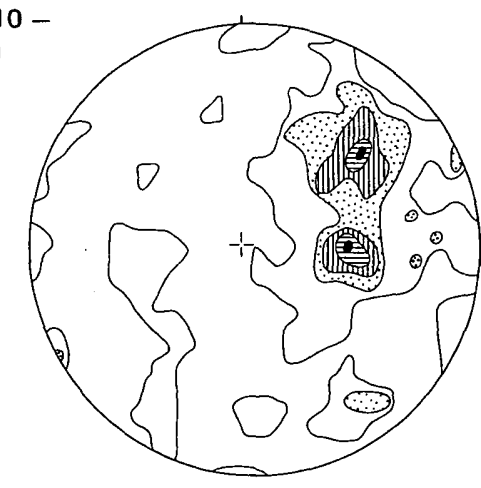
102 poles to beds;
$1,3,5,7,8$ percent

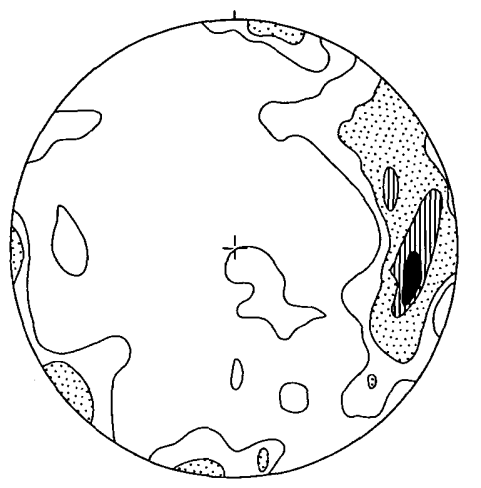

144 poles to cleavage;

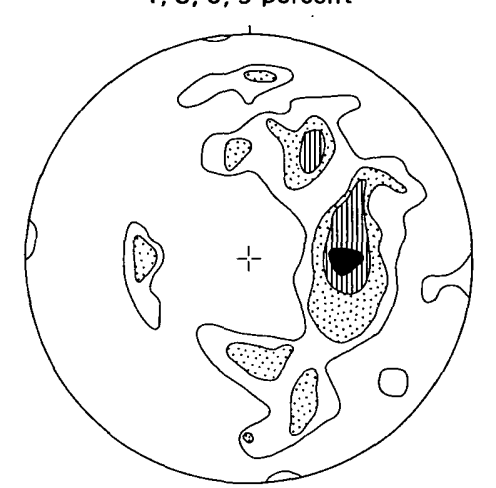

71 poles to cleavages:

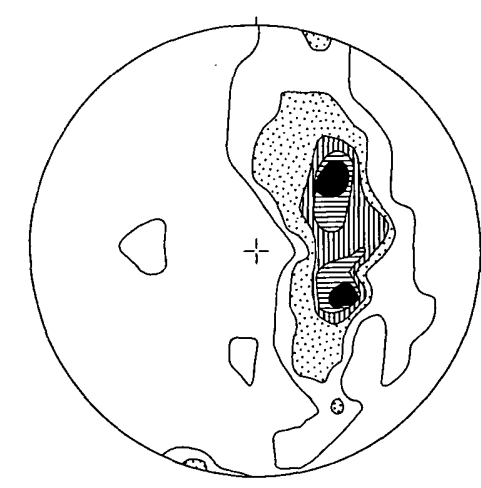

294 poles to cleavages:

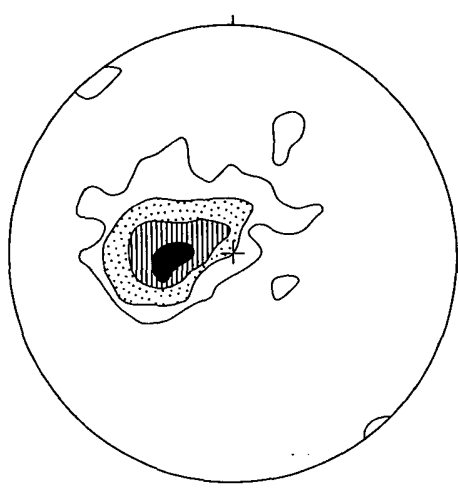

88 pencils; $1,3,9,20$ percent

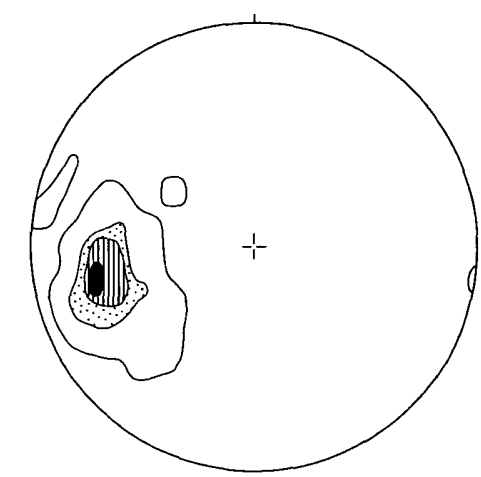

48 pencils; $2,8,16,29$ percent

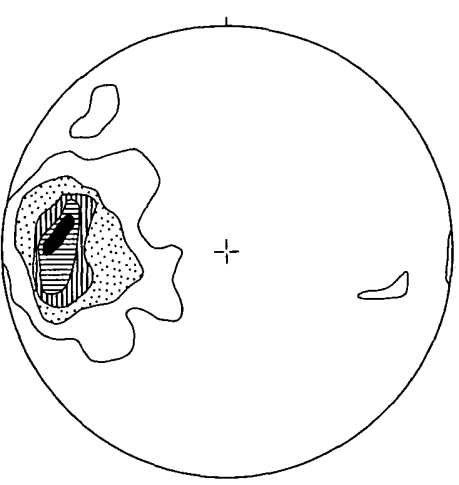

208 pencils; $1,4,8,12,16$ percent

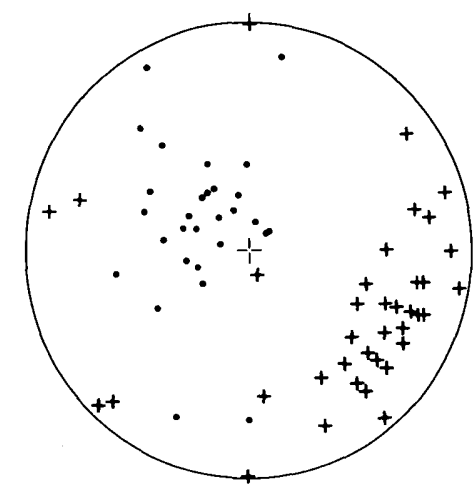

29 fold axes $(\cdot) ; 36$ poles

to axial planes $(+)$

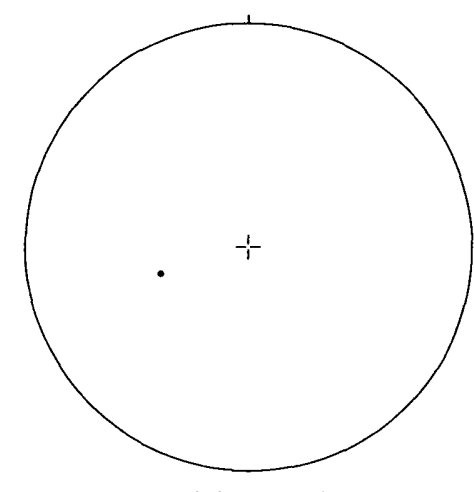

1 fold axis ( $)$ )

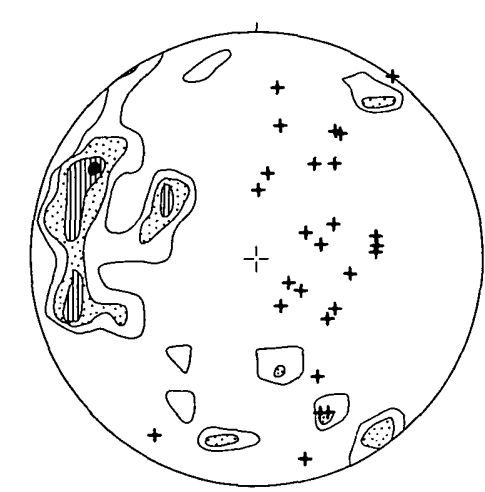

45 fold axes; $2,4,8,13$ percent: 26 poles to axial planes $(+)$ 

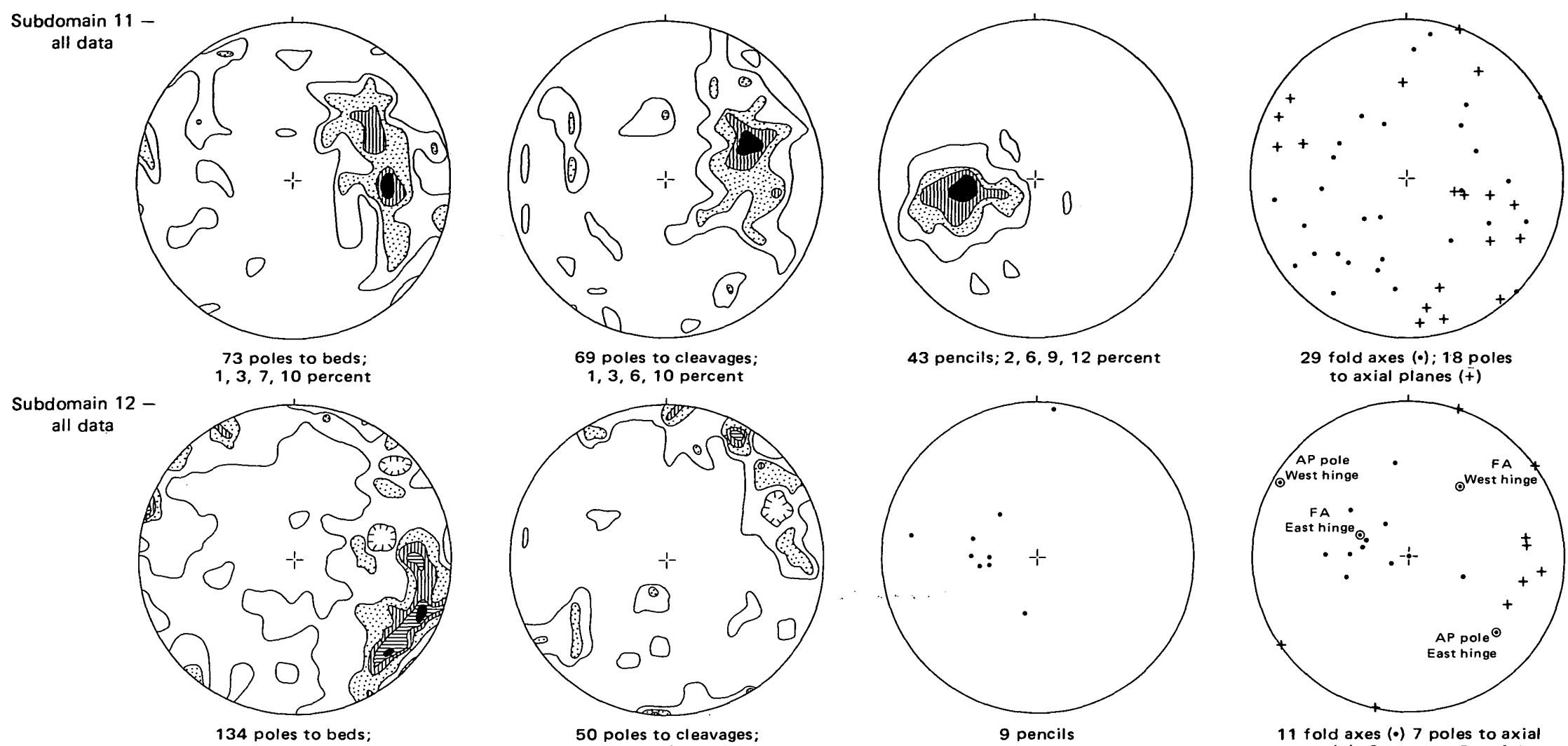

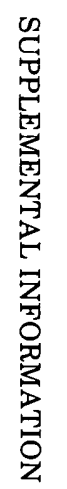

Subdomain 13 -

134 poles to beds;
$1,2,4,5,6$ percent all data
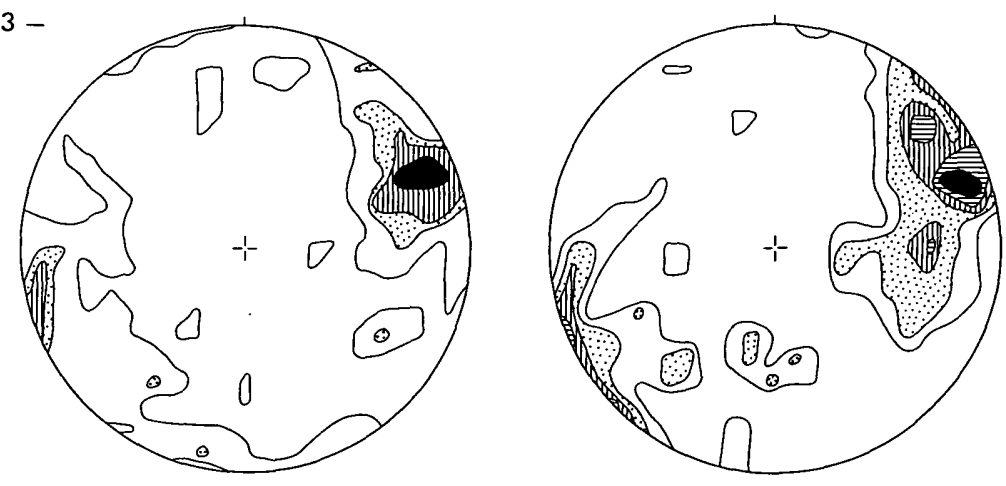

86 poles to cleavages:

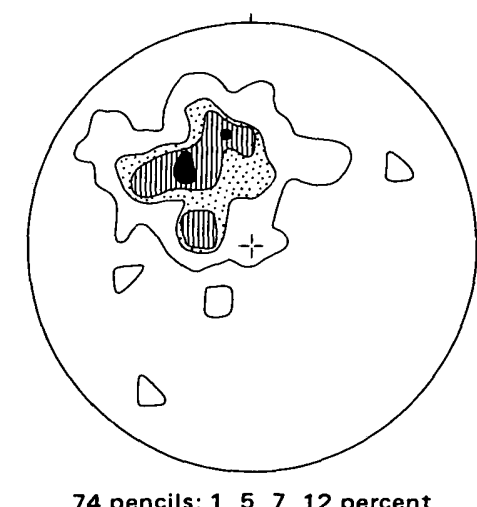

11 fold axes (.) 7 poles to axial planes ( + ): Constance Pass fold $\odot$

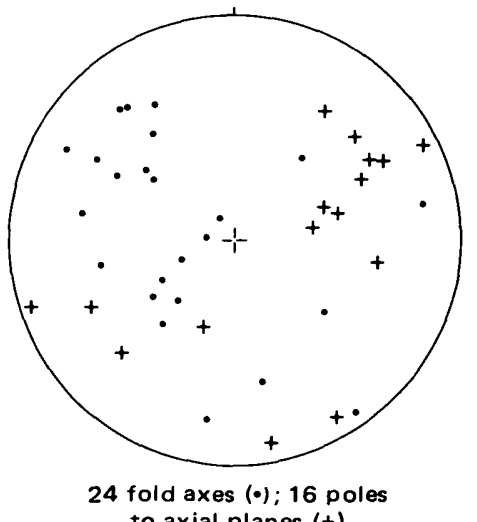


Subdomain 14 -

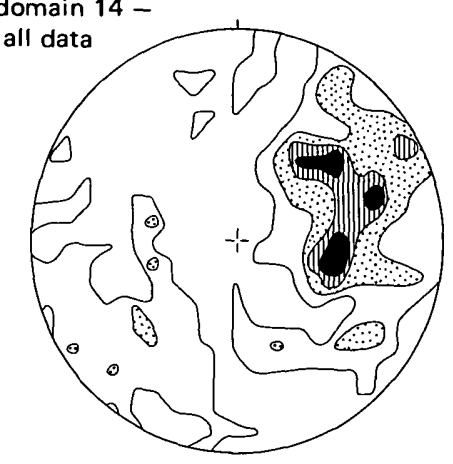

163 poles to beds: $1,2,4,5$ percent

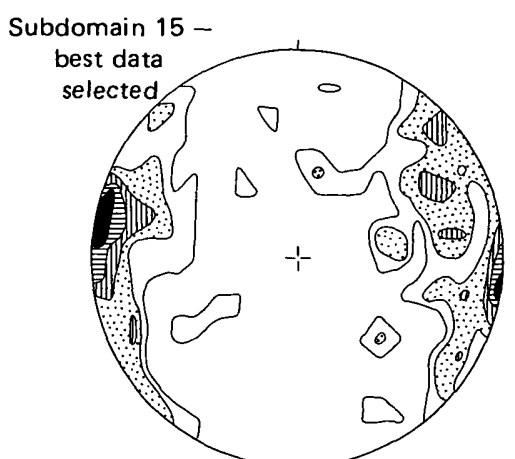

114 poles to beds; $1,2,4,6,10$ percent

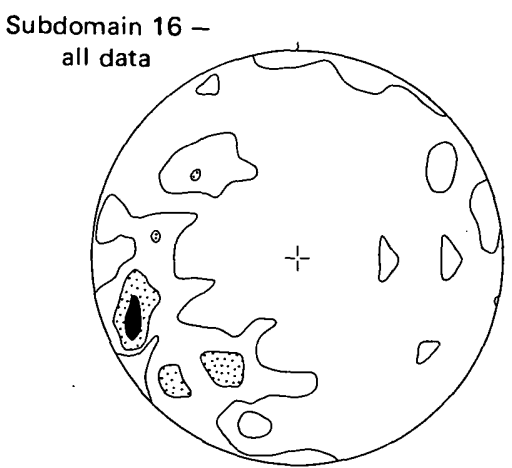

56 poles to beds; $2,5,9$ percent

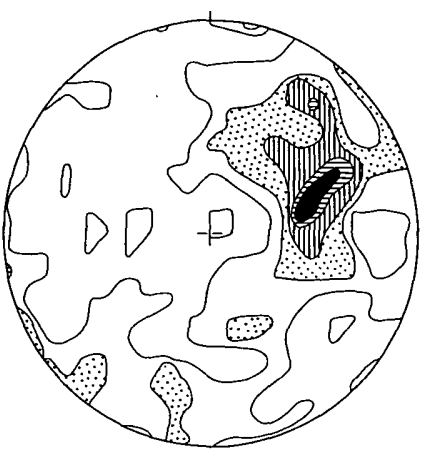

189 poles to cleavage

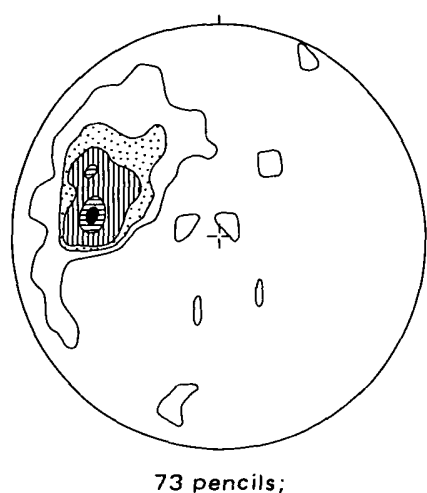

$4,8,12,16$ percent

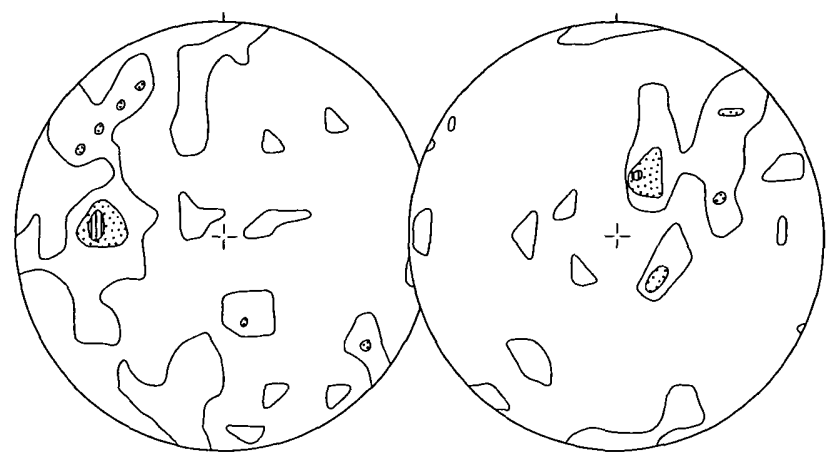

63 fold axes;

41 poles to axial planes:

$2,7,12$ percent

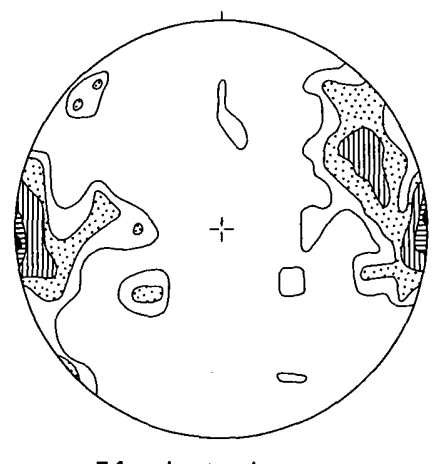

74 poles to cleavage:

$1,3,5,7,11,14$ percent

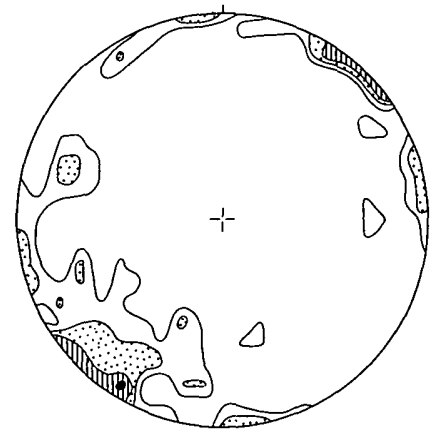

46 poles to cleavages;
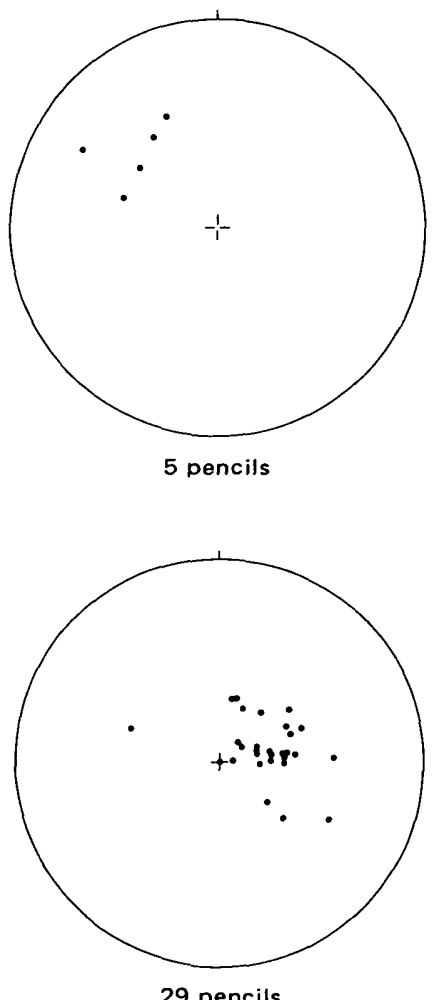

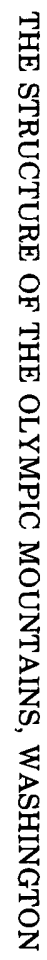

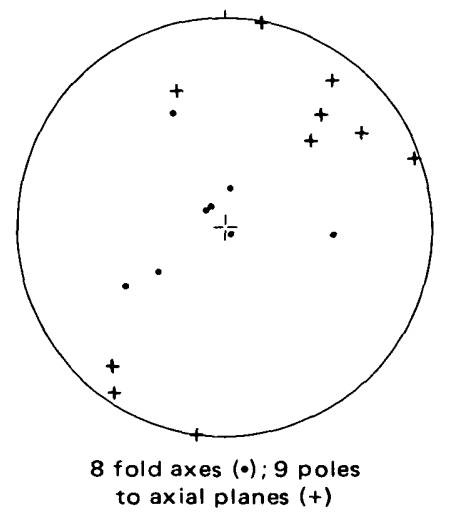

( +$)$

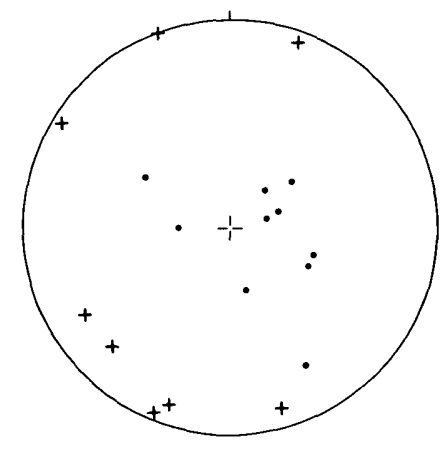

10 folds axes $(\cdot) ; 8$ poles to axial planes $(+)$ 

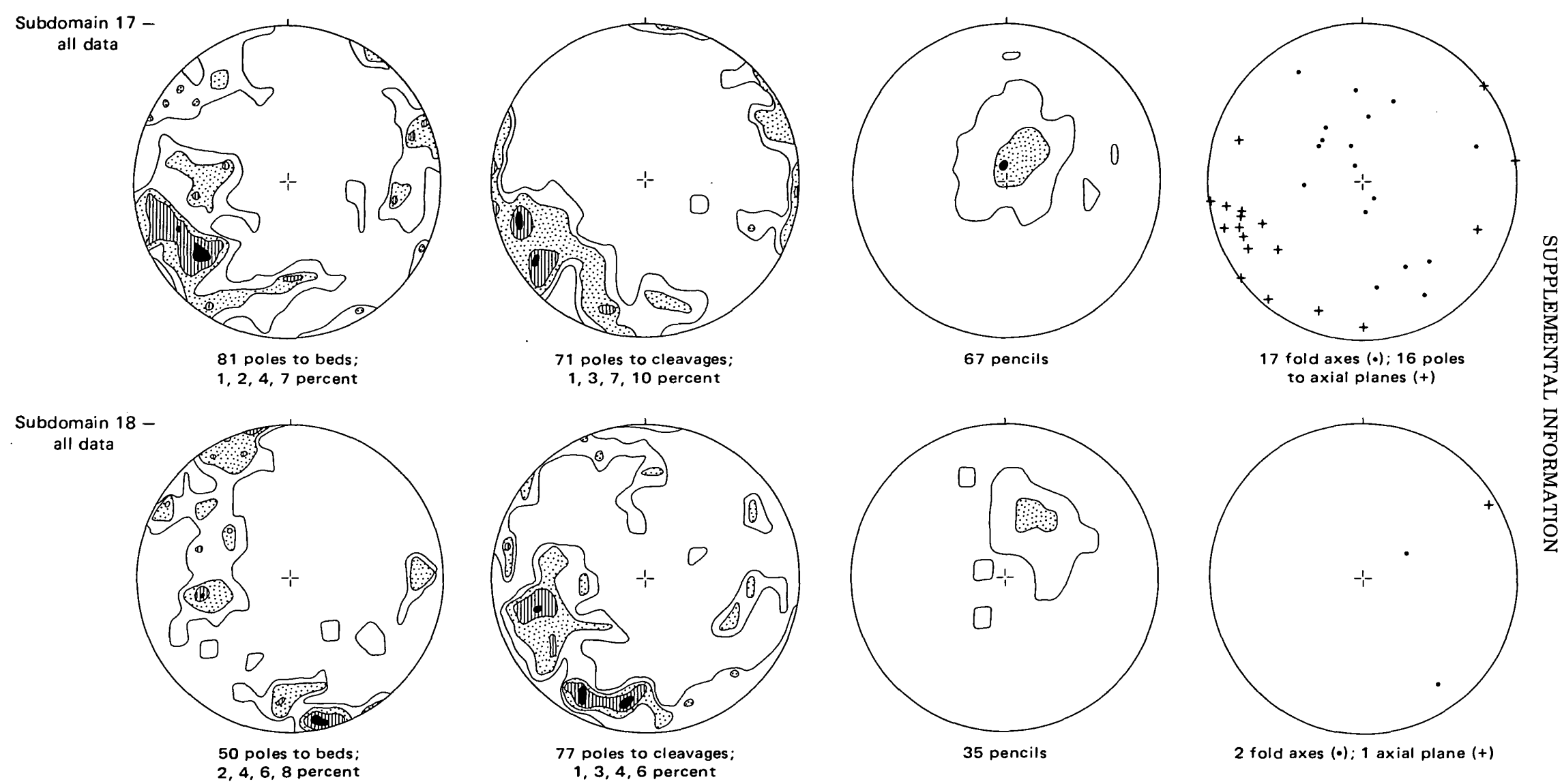


\section{COMPUTERIZED STRUCTURAL DIAGRAM PROGRAM}

In order to handle the large amounts of complex structural data obtained while mapping the Olympic Mountains, we established a two-part computer program in Fortran IV. The first part allows storage of the structural data on punchcards with provisions to select the data by type and geographic location (subdomain). The second part of the program prepares a pole-density orientation diagram from the selected data. The computer program for pole-density orientation diagrams was made at the University of Alberta by Muecke and Charlesworth (1966). Our orientation program deck is a duplicate of the Canadian deck, lent to us by Dr. Charlesworth. Ming Ko, of the U.S.G.S. Computer Center, modified the Canadian program for our needs.

The storage of data was facilitated by the use of forms (fig. 33) that we filled out in the field. Any type of line or plane can be entered on the form and treated by the program. We measured dips to the nearest $5^{\circ}$, strikes to the nearest $2^{\circ}$. Before the data were entered on punch cards, station coordinates were punched by use of a coordinatograph.

The program allows subdomains to be selected by coordinates and (or) indicated stations. If coordinates are used, each subdomain is outlined as nearly as possible by two rectangles, specified by their southwest and northeast corners. Stations can be added or subtracted individually to fill in irregular subdomains.

Because the Olympic rocks are particularly prone to sliding and slumping (see Tabor, 1971), we included an option of select data on the basis of field observation of reliability, a somewhat subjective judgment. We found that the results for all data and for only the best data were about the same. Most subdomains were run with all the data.

The following summary of the pole-density orientation program is modified from a description of the program by H. A. K. Charlesworth (written commun., 1967).
The program counts out points on the reference sphere, not on their projection in the equatorial plane. The pole densities obtained are then projected onto the equatorial plane and faithfully reflect the true pole densities.

The computer converts the strike, dip, and direction of a plane to the bearing and plunge of the normal to the plane. All the bearings and plunges are then changed into direction cosines of unit length.

The counting out of the poles in the reference sphere is accomplished by the use of a circular cone with semivertical angle, the value of which is determined by the percentage of the total area of the projection that the counter is required to cover. The percentage of the total area counted and the number of counting locations are chosen such that the counting cones overlap so as to assure that all points on the sphere are counted. At the same time, the counting area is kept small in order to obtain the best possible definition of any differences in the densities of the points.

The number of data readings in each data set falling within the counting cone at each counting locality is converted into the percentage of the total number of points processed.

In order to facilitate a simple output format for a line printer, the counting locations were chosen to form a regular grid and projected from the lower hemisphere of the reference sphere onto the equatorial plane by equal-area projection (fig. $34 B$ ). For the convenience of accurate contouring, these locations were augmented by 14 additional points near the periphery of the projection. We contoured the printed densities by hand; a subprogram that plots the projections of the pole intersections (fig. $34 A$ ) was especially useful in subdomains with small amounts of data.

In keeping with the spirit established by Muecke and Charlesworth, we maintain a program card deck with our modifications (data retrieval and plotting subroutine), available for loan and duplication. Address inquiries to R. W. Tabor, U.S. Geological Survey, 345 Middlefield Road, Menlo Park, Calif. 94025. 


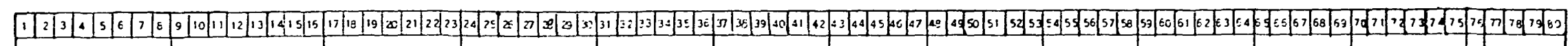

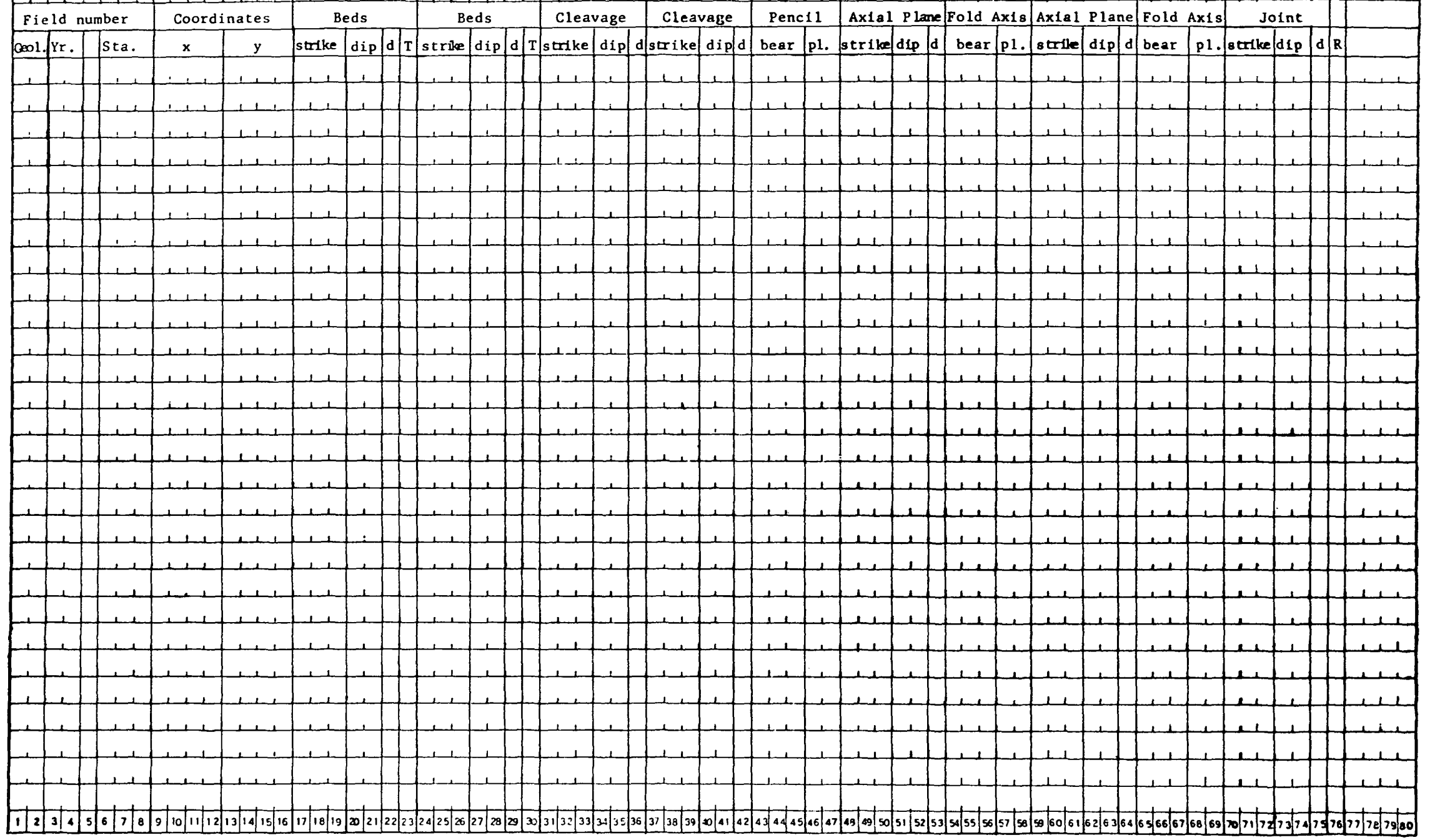

FIGURE 33.-Computer form for structural data. 

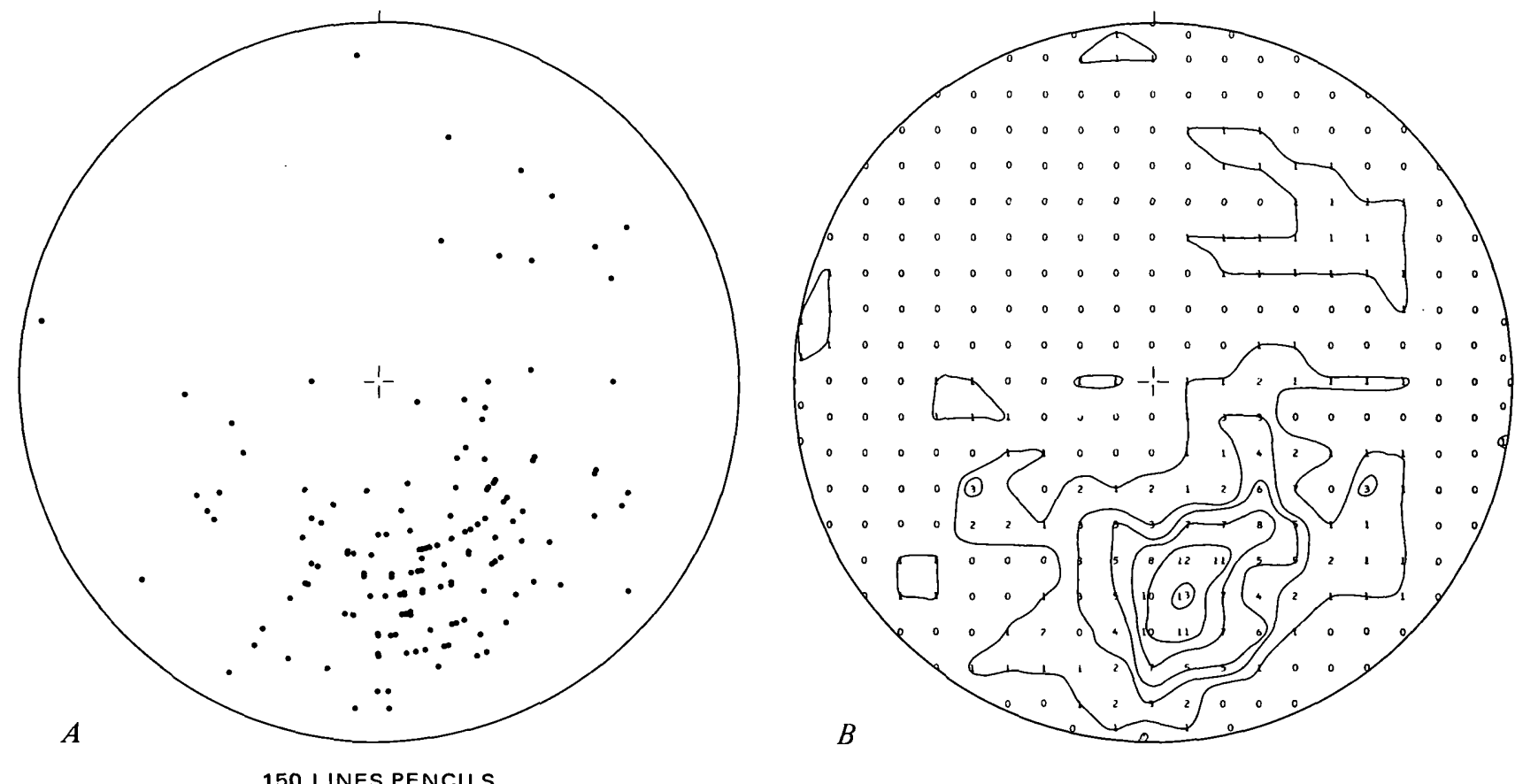